\title{
Acetabularia-Rhodopsin, eine lichtgetriebene Protonenpumpe aus einem autotrophen Eukaryoten
}

\author{
Dissertation \\ zur Erlangung des Doktorgrades \\ der Mathematisch-Naturwissenschaftlichen Fakultäten \\ der Georg-August-Universität zu Göttingen
}

vorgelegt von

David Ewers

aus Hannover

Göttingen 2005 
D7

Referent: Prof. Dr. D. Gradmann

Korreferent: Prof. Dr. R. Tischner

Tag der mündlichen Prüfung: 03.11.2005 


\section{Abstract}

A rhodopsin from Acetabularia acetabulum (AR) is characterized by molecular genetic and electophysiological means. On the basis of a published, incomplete sequence, the whole transcript of an opsin was isolated and cloned as complementary desoxy ribonucleic acid (cDNA) by reverse transcription and polymerase chain reaction, and sequenced. Analysis of the deduced amino acid sequence reveals a hypothetical protein that shares the primary and secondary structure of type 1 rhodopsins. It shows $21 \%$ identity with and $38 \%$ similarity to bacteriorhodopsin (BR). In addition to the rhodopsins' common seven transmembrane helices, AR seems to have an eighth helix at the C-terminus. Judging from characteristic, conserved amino acids found in the active center of the protein, AR is expected to be a light-driven proton pump. To characterize the electrical properties of AR, it was functionally expressed in oocytes of Xenopus laevis. Under voltage clamp, AR is found to indeed mediate a light-driven transport of protons against their electrochemical gradient. The stationary, positive current shows a sigmoidal voltage dependence. AR is the first rhodopsin of a eukaryote autotroph that is shown to function as an active ion transporter. The light induced current through AR is reminescent of the fast photoelectric effect in acetabularia, as it follows the onset of light after $<50 \mu \mathrm{s}$, is half maximal at a light intensity of $>10^{\wedge} 20$ photos per square meter and second, and has an action spectrum peaking at $520 \mathrm{~nm}$ (550 nm in vivo). 


\section{Kurzreferat}

Ein Rhodopsin aus Acetabularia acetabulum (AR) wird mit molekulargenetischen und elektrophysiologischen Mitteln charakterisiert. Mithilfe der reversen Transkription und der Polymerasekettenreaktion wurde auf der Grundlage einer veröffentlichten, unvollständigen Sequenz, das gesamte Transkript eines Opsins in Form komplementärer Desoxyribonukleinsäure isoliert, kloniert und sequenziert. Das aus der abgeleitete Aminosäurensequenz resultierende hypothetische Protein hat eine mit den Rhodopsinen des Typs 1 übereinstimmende Primär- und Sekundärstruktur. Die Aminosäurensequenz von $\mathrm{AR}$ zeigt 21\% Identität und 38\% Ähnlichkeit mit Bacteriorhodopsin. Es scheint außer den für Rhodopsine typischen sieben transmembranen Helices noch ein weiteres Transmembransegment in Nähe des C-Terminus $\mathrm{zu}$ besitzen. Aufgrund charakteristischer konservierter Aminosäuren im aktiven Zentrum des Proteins wird in AR eine lichtgetriebene Protonenpumpe vermutet. Um AR elektrophysiologisch zu charakterisieren, wurde es in Oozyten von Xenopus laevis funktionell exprimiert. Voltage-clamp-Untersuchungen bestätigten den lichtgetriebenen Transport von Protonen durch AR gegen ihren elektrochemischen Gradienten. Der stationäre positive Strom ist spannungsabhängig mit einer sigmoiden $I(V)$-Kurve. AR ist das erste in einem autotrophen Eukaryoten nachgewiesene Rhodopsin, das als aktiver Ionentransporter fungiert. Der lichtinduzierte Strom durch AR zeigt Ähnlichkeiten mit dem schnellen photoelektrischen Effekt in Acetabularia. So folgt die Antwort $<50 \mu$ s auf „Licht an“, hat eine halbmaximale Lichtintensität von $>10^{\wedge} 20$ Photonen pro Quadratmeter und Sekunde, und das Maximum des Aktionsspektrums liegt bei $520 \mathrm{~nm}$ (550 nm in vivo). 
Alle Gestalten sind ähnlich, und keine gleichet der andern, Und so deutet das Chor auf ein geheimes Gesetz, Auf ein heiliges Rätsel.

Johann Wolfgang von Goethe (Die Metamorphose der Pflanzen) 
Diese Arbeit entstand in der Zeit von August 2002 bis September 2005 in der Abteilung Biophysik der Pflanze des Albrecht-von-Haller-Instituts.

Zuerst danke ich Herrn Prof. Dr. Dietrich Gradmann dafür, dass er mich auf das Thema gestoßen hat und dann bis zuletzt die Rahmenbedingungen für die Entstehung dieser Arbeit geschaffen hat. Seine Kritik war angemessen und hilfreich.

Herr Prof. Dr. Rudolph Tischner war so freundlich, das Korreferat zu übernehmen.

Für die Anleitung zunächst aus der Nähe und dann aus der Ferne bin ich Herrn Prof. Dr. Peter Hegemann zu Dank verpflichtet, der an den entscheidenden Stellen die Richtung vorgegeben hat. Ohne die Kooperation seiner Arbeitsgruppe wäre die Arbeit ohnehin nicht entstanden.

Ich danke Frau Prof. Dr. Anna Moroni und ihrer Arbeitsgruppe für ihre Hilfe mit der Expression und der Elektrophysiologie.

Mein besonderer Dank gilt Dr. Satoshi Tsunoda für die Überlassung elektrophysiologischer Daten.

Dr. Mathias Schacht danke ich für seine Hilfe mit Unix-basierter Software.

Frau Hanna Bork danke ich für die Pflege der Acetabularien und für die die ausdauernde Ausübung ihrer Funktion als „Seele“ der alten Arbeitsgruppe. Ein Teil davon war das Freitagsfrühstück, das ohne sie leider ausfallen mußte.

Reiner Freter und Michael Koltermann haben mir bei unzähligen Gelegenheiten hilfreich zur Seite gestanden. Danke für die Jahre der guten Nachbarschaft.

Schließlich danke ich Dominika Mandrek-Ewers dafür, dass sie nicht nur mich, sondern auch meine Arbeit, die eigentlich keinem weiteren Zweck diente, über die Jahre begleitet hat. 


\section{Inhaltsverzeichnis}

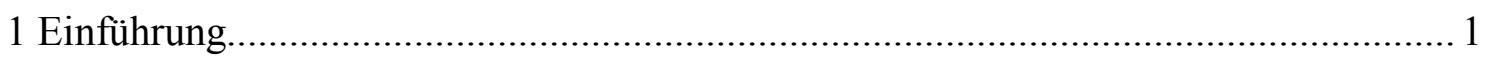

1.1 Rhodopsine

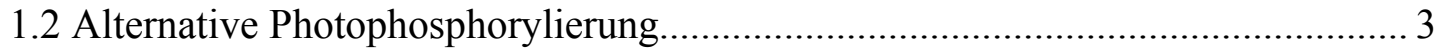

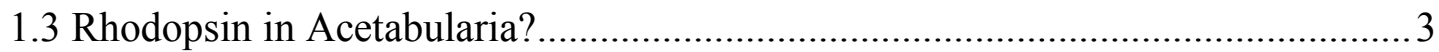

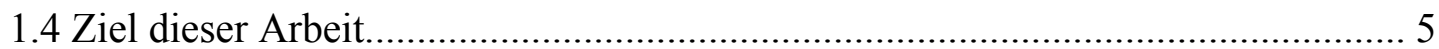

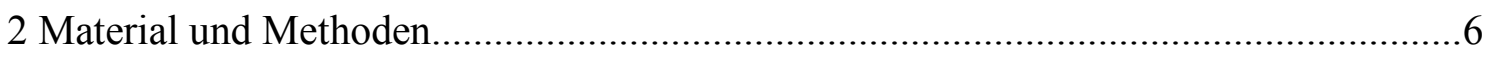

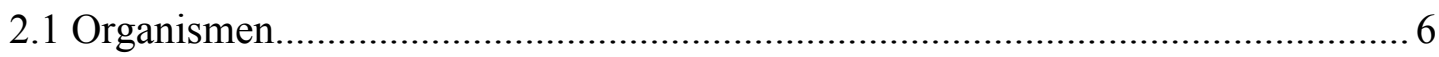

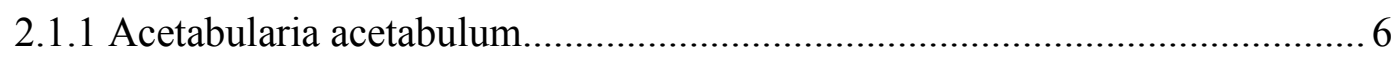

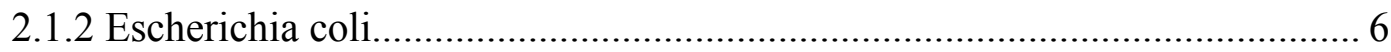

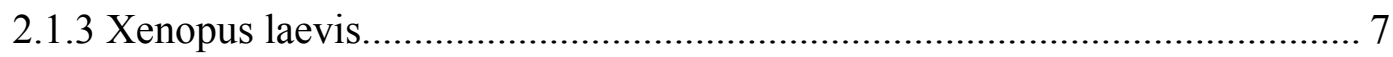

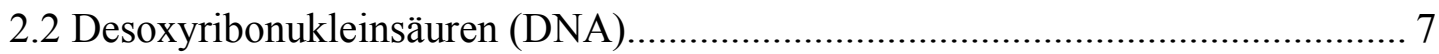

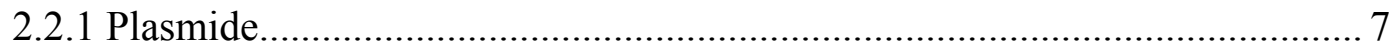

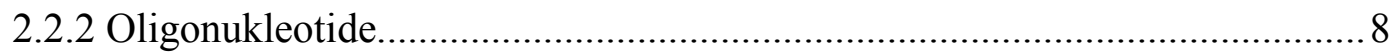

2.3 Elektronische Verarbeitung von DNA-Sequenzen........................................... 8

2.4 Reinigung von Nukleinsäuren........................................................................

2.4.1 Phenol/Chloroform-Extraktion............................................................ 9

2.4.2 Fällung von Nukleinsäuren.............................................................. 10

2.4.3 Reinigung von DNA mithilfe von Silicagel-Membran-Säulen.................... 11

2.5 Konzentration und Reinheit von Nukleinsäuren in Lösungen.............................. 11

2.6 Auftrennung von Nukleinsäuren im elektrischen Feld...................................... 11

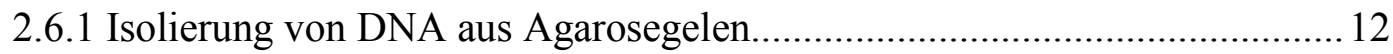

2.7 Enzymatische Spaltung und Verknüpfung von DNA....................................... 12

2.7.1 Fragmentierung von DNA mit Endonukleasen.......................................... 12

2.7.2 Ligation von DNA-Fragmenten............................................................. 13

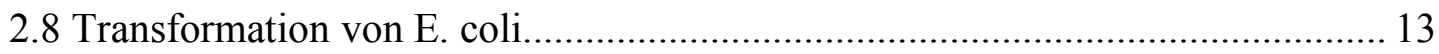

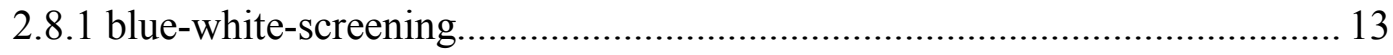

2.9 Präparation von Plasmid-DNA aus E. coli........................................................ 14

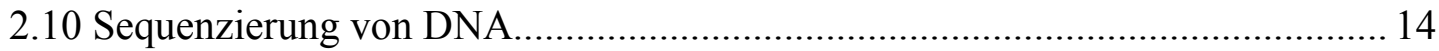

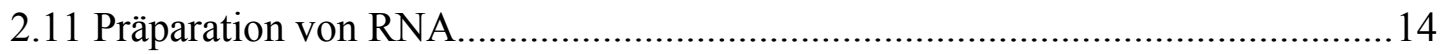

2.11.1 Extraktion von Gesamt-RNA aus A. acetabulum.................................... 15

2.11.2 Isolierung von messenger-RNA (mRNA) ........................................... 15 
2.12 Synthese komplementärer DNA (cDNA).

2.13 Erzeugung homopolymerer DNA-Enden (homopolymeric tailing)..... .17

2.14 Polymerasekettenreaktion (PCR)

2.14.1 Vervielfältigung unbekannter cDNA-Enden (Rapid Amplification of cDNA-Ends (RACE)). 19

2.14.2 Erzeugung von Genklonen voller Länge ...............................................20

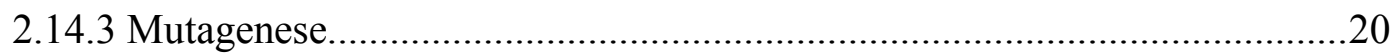

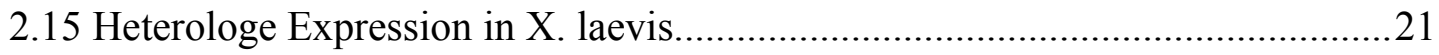

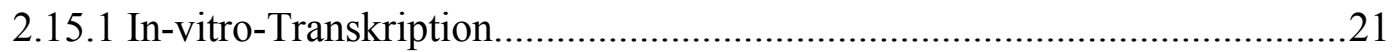

2.15.2 Präparation und transiente Transformation der Oozyten...........................21

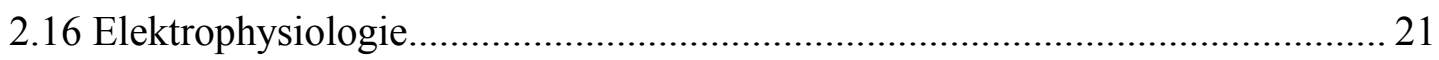

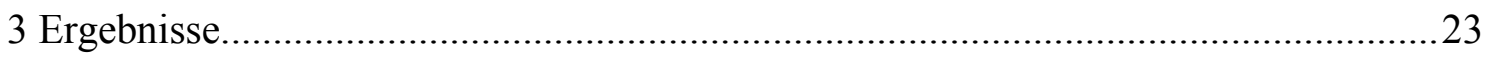

3.1 Nachweis eines Opsin-Transkripts in Acetabularia acetabulum.........................23

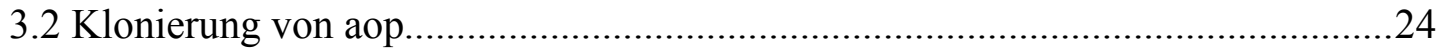

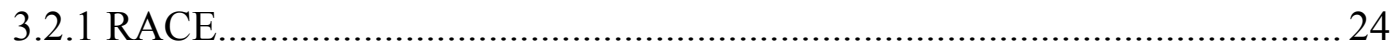

3.2.2 Klonierung des vollständigen Transkripts.................................................25

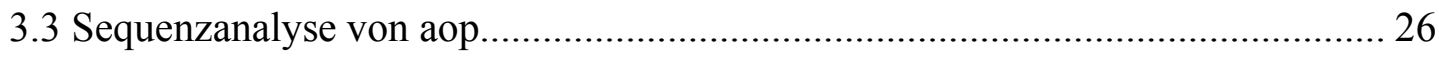

3.3.1 Sequenz des vollständigen Transkripts.................................................... 26

3.3.2 Analyse der abgeleiteten Aminosäurensequenz von AOP........................... 30

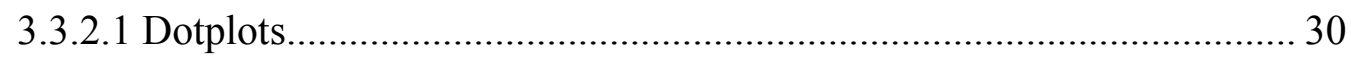

3.3.2.2 Voraussage der Topologie............................................................. 32

3.3.2.3 Multiple Sequence Alignment.......................................................... 33

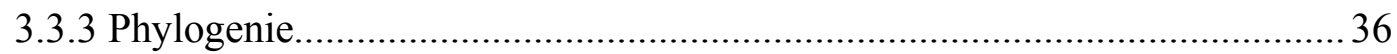

3.4 Heterologe Expression von AOP in Oozyten von X. laevis................................. 37

3.4.1 Anpassung des genetischen Codes........................................................... 37

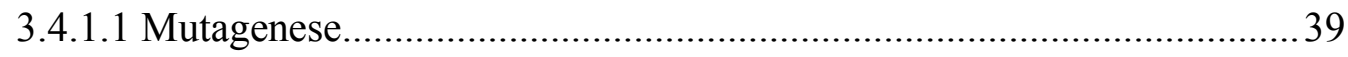

3.4.1.2 Klonierung in den Expressionsvektor pSGEM.................................. 39

3.4.2 Elektrische Eigenschaften von in Xenopus-Oozyten exprimiertem AR....... 40

3.4.2.1 Einfluss von Membranspannung und $\mathrm{pH}$ auf die lichtinduzierten Ströme

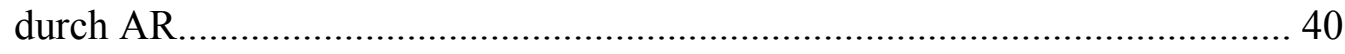

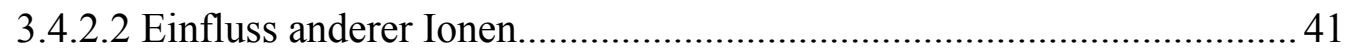

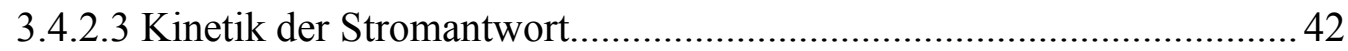

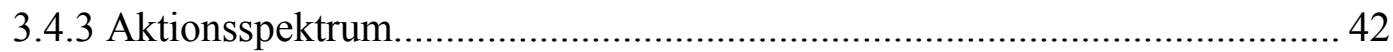

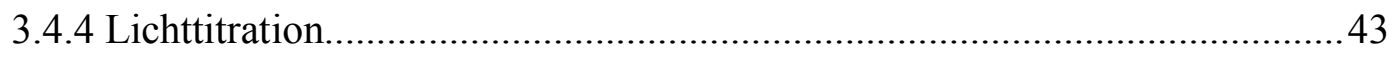




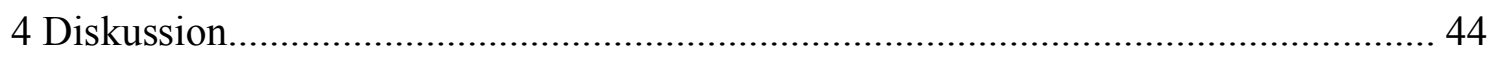

4.1 Klassifizierung von AOP anhand von Sequenzvergleichen.............................. 44

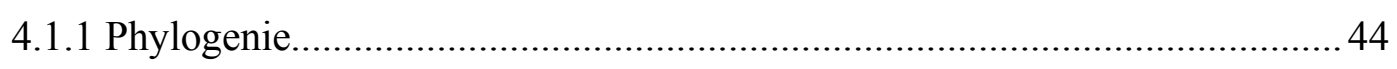

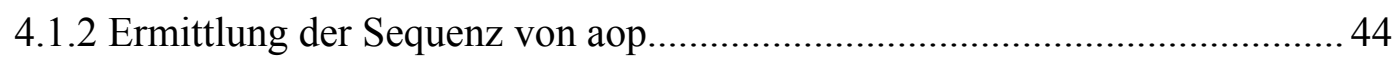

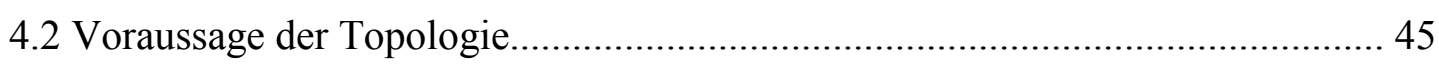

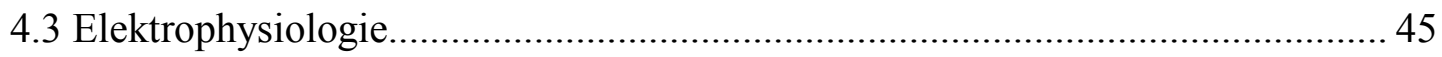

4.4 Vergleich der lichtinduzierten Ströme durch AR mit dem schnellen photoelektrischen Effekt von Acetabularia................................................................46

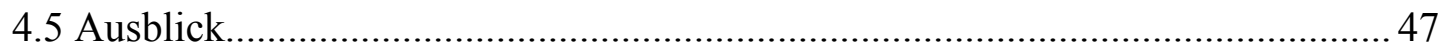

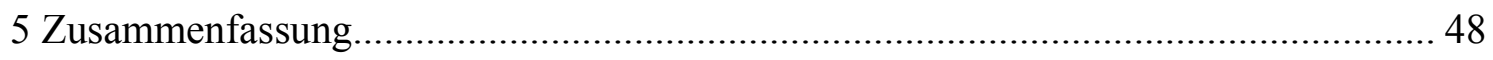

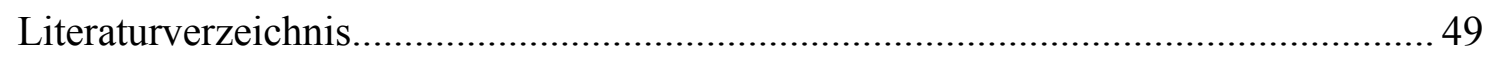




\section{Verzeichnis der Abkürzungen}

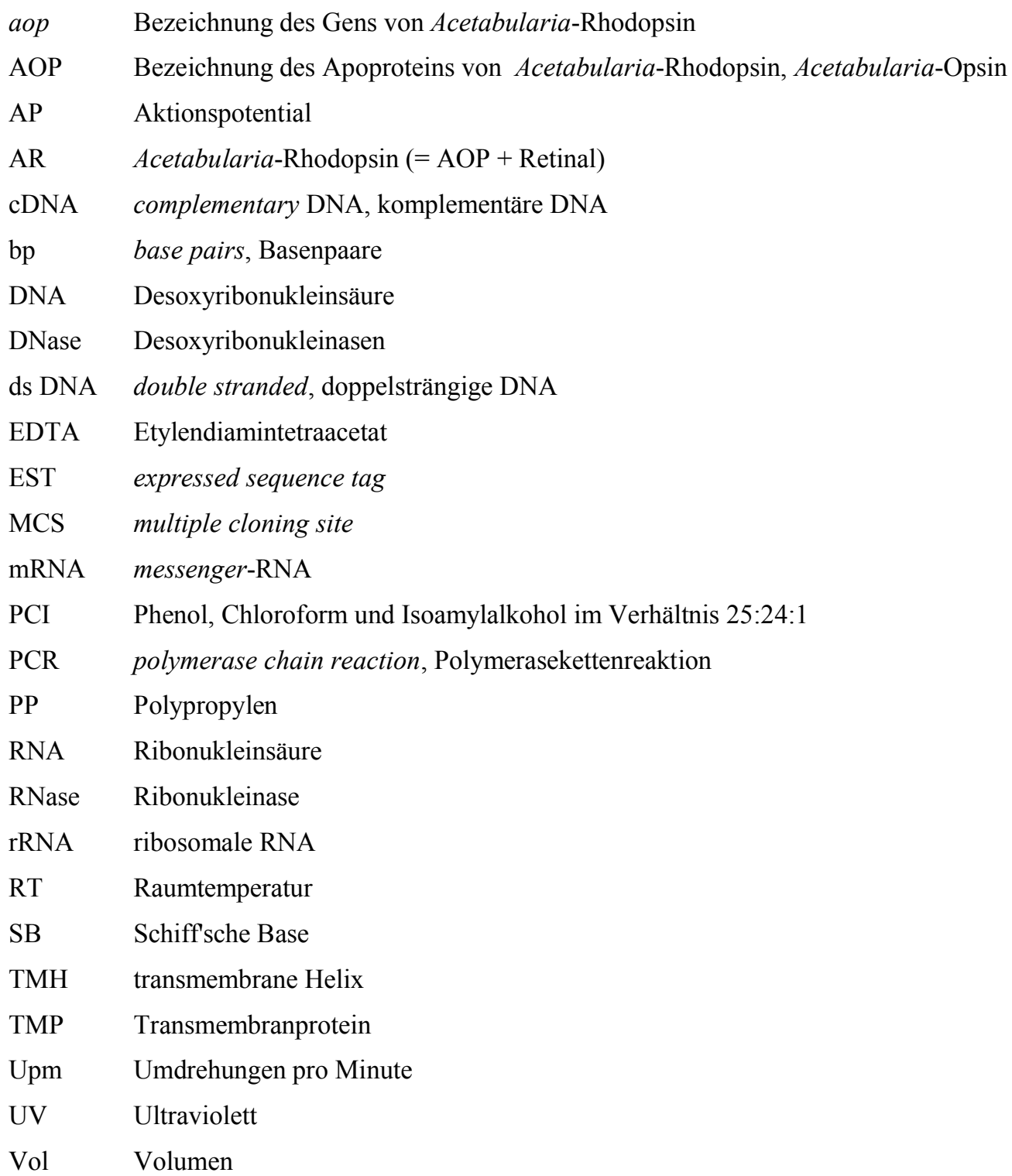




\section{Einführung}

\subsection{Rhodopsine}

Bis zu $30 \%$ aller Proteine sind an oder in Biomembranen zu finden (BOYD et al., 1998). Das ist keine Überraschung, denn diese biotischen Fettfilme begrenzen nicht nur die Kompartimente, in denen sich Lebensvorgänge abspielen, vielmehr sind auch sie selbst ein solches Kompartiment. Die zentralen Vorgänge des Energiestoffwechsels und des Stoff- und Informationstransports werden von Proteinen getragen, die in Membranen eingebettet sind (integrale oder Transmembran-Proteine, TMPe) oder mit TMPen assoziiert sind.

Eine strukturelle und funktionelle Gruppe solcher TMPe, die in ihrer Funktion als Lichtrezeptoren an beiden zentralen Vorgängen beteiligt sind, bilden die Rhodopsine. Sie bestehen aus sieben $\alpha-$ Helices, welche die Membran in abwechselnden Richtungen durchspannen (transmembrane Helices, TMHs), verbunden durch cytoplasmatische oder extrazelluläre Schleifen (loops). An ein Lysin etwa in der Mitte der siebten Helix ist

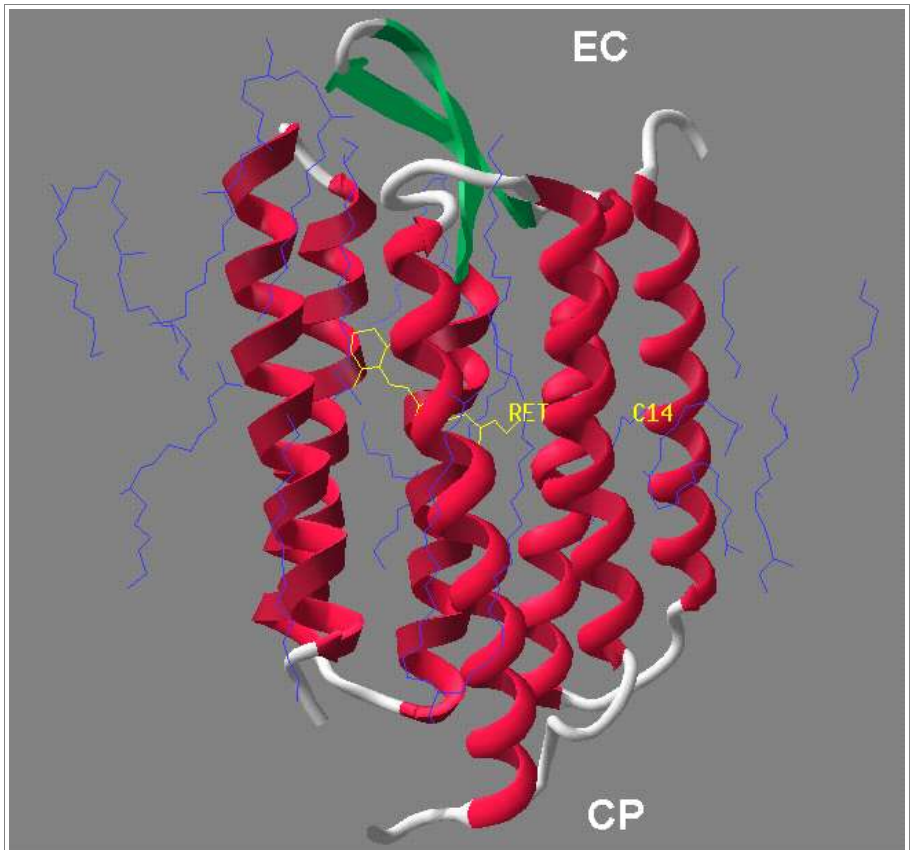

Abbildung 1.1: Tertiärstruktur von Bacteriorhodopsin, dem prominentesten Vertreter der Typ-1-Rhodopsine. Retinal, geordnete Lipide und Aminosäuren in TMHs, loops und $\beta$ sheets und sind farblich gekennzeichnet; EC: extrazelluläre Seite, CP: cytoplasmatische Seite. Zur Modellierung wurden die Koordinaten 1C3W (LUECKE et. al, 1999) der Protein Databank (BERNSTEIN et al., 1977) verwendet. der Cofaktor Retinal in Form einer Schiff'schen Base (SB) kovalent gebunden (s. Abb. 1.1).

Man unterscheidet bei den Rhodopsinen zwei Familien, zwischen denen, besitzen sie auch eine ähnliche Tertiärstruktur, geringe Sequenzähnlichkeit besteht und deren 
phylogenetische Beziehungen noch diskutiert werden (vgl. DEININGER et al., 2000). Rhodopsine vom Typ 1 waren lange Zeit nur in Archebakterien bekannt, kommen aber auch in den anderen Reichen des Lebens (Eubakterien, Eukaryoten) vor. Sie fungieren als lichtgetriebene Ionenpumpen (Bacteriorhodopsin, BR, STOEKENIUS \& OESTERHELT, 1973; Halorhodopsin, HR, SCHOBERT \& LANYI, 1982), lichtgesteuerte Ionenkanäle (Channelopsin, CHOP, SINESHCHEKOV et al., 2002, NAGEL et al., 2002) und transducer-gekoppelte Photorezeptoren (Sensory Rhodopsin, SR, BOGOMOLNI \& SPUDICH, 1982). Rhodopsine vom Typ 2 sind die Photorezeptoren der visuellen Systeme der Metazoa, allesamt G-Protein-gekoppelte Rezeptoren (Übersicht über Rhodopsine: SPUDICH et al., 2000) .

Die lichtinduzierte Konformationsänderung (Photoisomerisierung, s. Abb. 1.2) des Retinals von all-trans nach 13-cis (Typ-1Rhodopsine) oder 11-cis nach all-trans (Typ-2-Rhodopsine) ist die Grundlage der Lichtempfindlichkeit

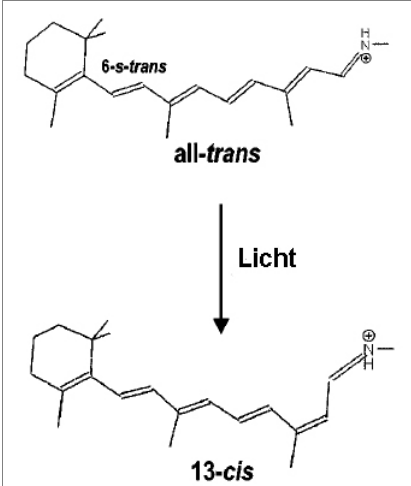

Abbildung 1.2: Retinal, der Cofaktor aller Rhodopsine, und seine Photoisomerisierung, links in Typ-1-Rhodopsinen und rechts in Typ-2-Rhodopsinen

Rhodopsine. Sie steht am Anfang einer Folge von photochemischen Reaktionen, die jeweils distinkte Konformationsänderungen im aktiven Zentrum (sog. retinal-binding pocket) nach sich ziehen. In Typ-1-Rhodopsinen wird diese Folge von Reaktionen mit ihren zunächst spektroskopisch nachgewiesenen Übergangszuständen (photointermediates) als photocycle bezeichnet (LOZIER et al., 1975), der für BR so aussieht (nach VARO \& LANYI, 1991 und HAUPTS et al., 1999):

$$
B R_{570} \Rightarrow K_{590} \Leftrightarrow L_{550} \Leftrightarrow M_{410}^{E C} \Rightarrow M_{410}^{C P} \Leftrightarrow N_{560} \Leftrightarrow O_{640} \Rightarrow B R_{570}
$$

Die wichtigsten Schritte beinhalten die Photoisomerisierung des Retinals $\left(B R_{570} \Rightarrow K_{590}\right)$, Deprotonierung der SB mit $\mathrm{Asp}^{85}$ in der Nähe der extrazellulären (EC) Seite als Akzeptor $\left(L_{550} \Leftrightarrow M_{410}^{E C}\right)$, Veränderung in der Zugänglichkeit (access) der SB für die an der Protonenleitung beteiligten Aminosäuren $\left(M_{410}^{E C} \Rightarrow M_{410}^{C P}\right)$, Transport eines Protons von $\mathrm{Asp}^{85}$ auf die EC-Seite und gleichzeitige Reprotonierung der SB durch $\mathrm{Asp}^{95}$ in der Nähe der cytoplasmatischen (CP) Seite $\left(M_{410}^{C P} \Leftrightarrow N_{560}\right)$, Transport 
eines Protons von der EC zu Asp ${ }^{95}$ und dessen Reprotonierung $\left(N_{560} \Leftrightarrow O_{640}\right)$, ReIsomerisierung der SB $\left(N_{560} \Leftrightarrow O_{640}\right)$ und Rückkehr der Zugänglichkeit der SB in den Ausgangszustand $\left(O_{640} \Rightarrow B R\right)$. Rhodopsine vom Typ 2 durchlaufen eine ähnliche Reaktionsfolge, allerdings wird dabei die kovalente Bindung des Retinals zerstört und das Pigment gebleicht (Übersicht: HOFMANN, 1999). Die Re-Isomerisierung des Retinals wird ebenfalls von retinalbindenden Proteinen katalysiert, den Retinochromen (PEPE \& CUGNOLI, 1992).

\subsection{Alternative Photophosphorylierung}

Der am Besten untersuchte Vertreter der Typ-1-Rhodopsine, BR, erzeugt in dem halophilen Archebakterium Halobacterium salinarium einen elektrochemischen Gradienten und dient so zu einer von einer Elektronentransportkette unabhängigen Photophosphorylierung. Diese Alternative zur Lichtreaktion der Photosynthese der Pflanzen (Übersicht: OESTERHELT, 1999) wird wohl nicht nur von urtümlichen Extremophilen in isolierten Ökosystemen genutzt, sondern seit neueren Erkenntnissen auch in dem globalen Ökosystem des Oberflächenwassers der Weltmeere (BEJA et al., 2000), wo sie vielleicht für einen nicht unerheblichen Anteil der metabolischen Energiekonvertierung verantwortlich ist. Schließlich wurde der selbe Mechanismus in einem Eukaryoten, dem Pilz Leptosphaeria maculans, postuliert. Leptosphaeriarhodopsin (LR) ist eine lichtgetriebene Protonenpumpe (WASCHUK et al. (2005)). In autotrophen Eukaryoten wurde ein alternativer Weg der Photophosphorylierung bisher nicht vermutet, nutzen diese Organismen doch bereits die Lichtreaktion der Photosynthese.

\subsection{Rhodopsin in Acetabularia?}

Acetabularia (Abb. 1.3, Dasycladales) ist eine einzellige Meeresalge, die siphonal organisiert ist, d. h. sie besteht aus einer einzigen, langgestreckten Riesenzelle mit je nach Stadium der Ontogenese einem oder vielen Zellkernen. Einst ein viel beforschter Modellorganismus (vgl. GIBOR, 1966), wurde Acetabularia durch ihre Größe (mehrere cm Länge) bei Fehlen von Querwänden auch zu einem Objekt elektrophysiologischer Studien. SCHILDE entdeckte 1966 im Zuge elektrophysiologischer Messungen mit 
intrazellulären Elektroden, dass Licht in Acetabularia Aktionspotentiale (AP) induziert, welche die Zelle, ähnlich einem Axon der Metazoa, entlanglaufen. Dabei findet auf ,Licht an" hin eine schnelle, transiente Depolarisation vom Ruhepotential (RP, $-170 \mathrm{mV}$ ) statt, gefolgt von einer langsamen Hyperpolarisation (schneller

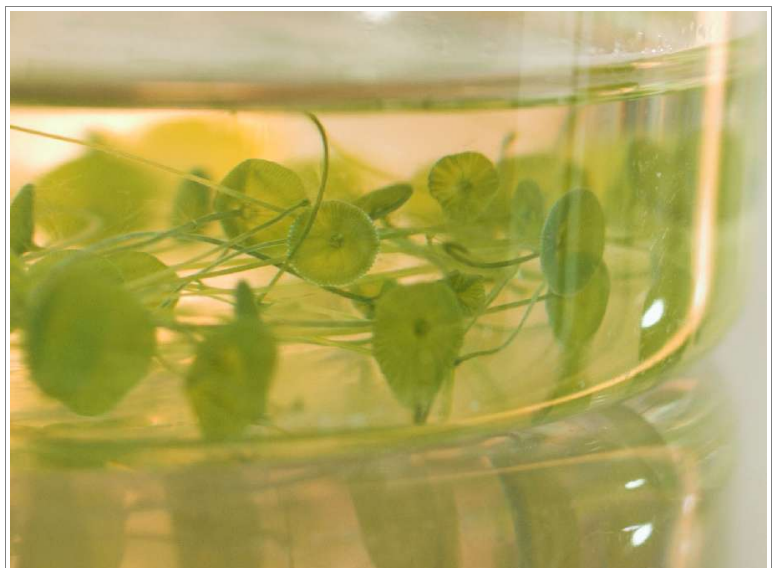
Abbildung 1.3: Acetabularia acetabulum in Kultur. und langsamer photoelektrischer AnEffekt). Auf „Licht aus“ hin ist zunächst eine schnelle Hyperpolarisation zu beobachten, dann eine langsame starke Depolarisation, woraufhin die Spannung nach Erreichen eines Maximums $(-70 \mathrm{mV})$ wieder auf das RP zurückfällt (schneller und langsamer photoelektrischer Aus-Effekt).
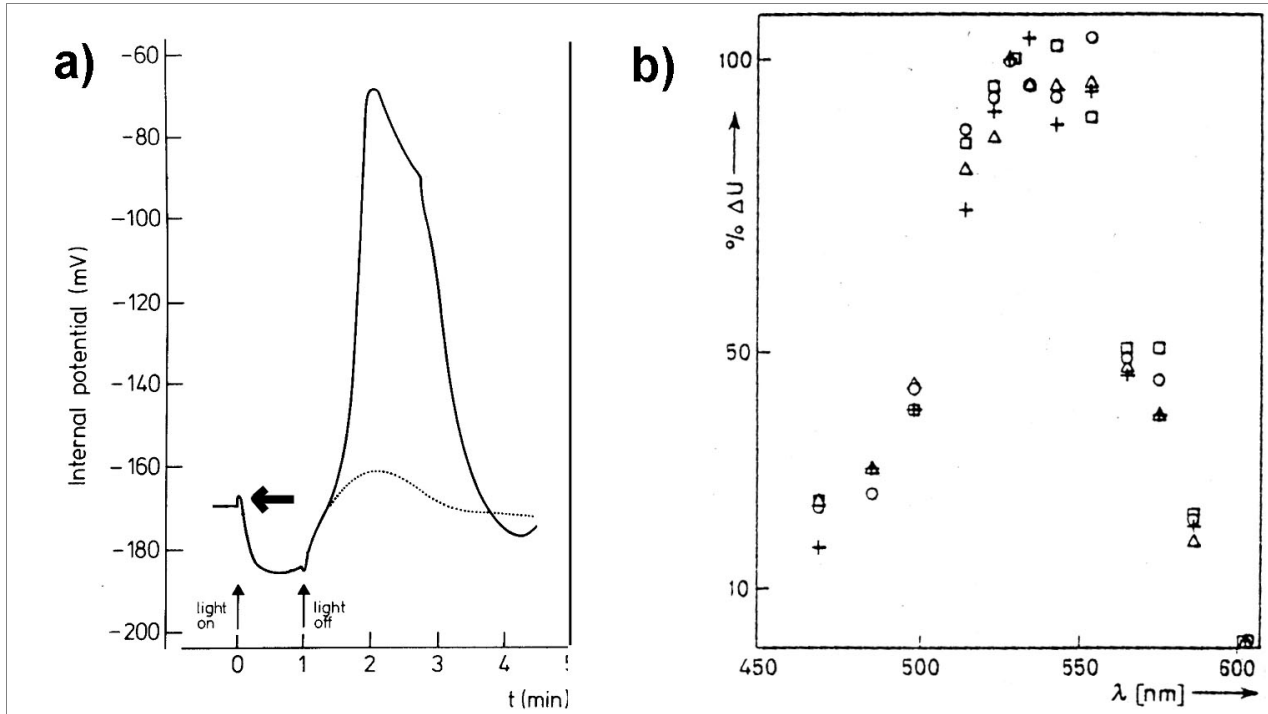

Abbildung 1.4: a) AP von Acetabularia mit schnellem photoelektrischem An-Effekt (waagerechter Pfeil, nach GRADMANN, 1978), und b) dessen Aktionsspektrum (nach SCHILDE, 1968).

Abb. 1.4 zeigt den schnellen photoelektrischen An-Effekt am Beginn des APs. SCHILDE (1968) vermutete für dieses sensorische Phänomen ein Rhodopsin als Photorezeptor, da das Aktionsspektrum des schnellen photoelektrischen An-Effekts dem von visuellen Rhodopsinen der Metazoa entspricht (Abb. 1.4, rechts), jedoch zog er auch ein Cytochrom in Betracht. GRADMANN (1978) erklärte den Effekt mit einer Hemmung einer bisher nicht isolierten elektrogenen $\mathrm{Cl}^{-}$-ATPase.

In jüngerer Zeit wurde vergeblich versucht, das postulierte Rhodopsin von Acetabularia 
mit molekularbiologischen Methoden zu identifizieren (EWERS, 2002). HENRY et al. (2004) veröffentlichten jedoch vor kurzem die Sequenz eines mutmaßlichen OpsinTranskripts aus einer expressed-sequence-tag(EST)-Bibliothek (accession number beim National Center for Biotechnology Information, NCBI: CF259014), für die sie Homologie mit Leptosphaeria-Opsin (LOP) feststellten.

\subsection{Ziel dieser Arbeit}

Die von HENRY et al. (2004) als EST eines mutmaßlichen Opsingens veröffentlichte cDNA-Sequenz sollte neuer Ausgangspunkt zur Identifizierung eines Opsins in Acetabularia sein. Dafür sollte zunächst das Transkript als cDNA nachgewiesen, vervollständigt und kloniert werden. Heterologe Expression in Oozyten von Xenopus laevis sollte dann eine elektrophysiologische Charakterisierung ermöglichen. 


\section{Material und Methoden}

\subsection{Organismen}

\subsubsection{Acetabularia acetabulum}

A. acetabulum wurde in Glasschalen mit künstlichem Meerwasser (PROVASOLI et al., 1957, modifiziert nach MÜLLER (1962): $475 \mathrm{mM} \mathrm{NaCl}, 9,8 \mathrm{mM} \mathrm{KCl,} \mathrm{26,6} \mathrm{mM}$ $\mathrm{MgSO}_{4}, 26 \mathrm{mM} \mathrm{MgCl} 2,13,5 \mathrm{mM} \mathrm{CaCl} 2,2,4 \mathrm{mM} \mathrm{NaHCO}{ }_{3}, 1,18 \mu \mathrm{M} \mathrm{NaNO}, 14 \mu \mathrm{M}$ $\mathrm{Na}_{2} \mathrm{HPO}_{4}, 70 \mu \mathrm{M} \mathrm{Na} \mathrm{SiO}_{3}, 14 \mu \mathrm{M} \mathrm{ZnCl}_{2}, 3,8 \mu \mathrm{M} \mathrm{MnSO}_{4}, 830 \mathrm{nM} \mathrm{Na} \mathrm{MoO}_{4}, 40 \mathrm{nM}$ $\mathrm{CoCl}_{2}, 8 \mathrm{nM} \mathrm{CuSO}_{4}, 57,3 \mu \mathrm{M}$ Etylendiamintetraacetat (EDTA), 1,2 $\mu \mathrm{M}$ Fe-II-citrat, 32 $\mu \mathrm{M}$ Borsäure, $185 \mu \mathrm{M} \mathrm{NaBr}, 14 \mu \mathrm{M} \mathrm{SrCl}_{2}, 210 \mathrm{nM} \mathrm{AlCl}_{3}, 130 \mathrm{nM} \mathrm{RbCl}, 140 \mathrm{nM} \mathrm{LiCl}$, $120 \mathrm{nM} \mathrm{NaJ}, 500 \mathrm{ng} / 1$ Vitamin B 12, $500 \mathrm{ng} / 1$ Biotin, $100 \mu \mathrm{g} / 1$ Thiamin; sterilfiltriert) nach SCHWEIGER et al. (1977) bei einem Licht:Dunkel-Zyklus von 14:10 h kultiviert.

\subsubsection{Escherichia coli}

Der Stamm XL1-blue (BULLOCK et al. 1987, Genotyp: supE hsdR lac F' $^{\prime}$ proAB $^{+}$lacl $^{q}$ lacZ $\Delta \mathrm{M} 15)$ diente als Wirt für Klonierungen, also zur Aufnahme und Vermehrung von Plasmiden, die durch Ligation von Produkten der Polymerasekettenreaktion (PCR, s. a. 2.14) oder Restriktionsfragmenten mit Vektoren entstanden. Aufgrund eines defekten lacZ-Gens ist der Stamm für die $\alpha$-Komplementierung geeignet (ULLMANN et al., 1967, 2.2.1), welche ein sog. blue-white-screening zur Erkennung rekombinanter Klone ermöglicht (HORWITZ et al., 1978).

Die Bakterien wurden in Luria-Bertani(LB)-Medium (1 \% Bacto-Trypton (DIFCO, USA), 0,5 \% Hefe-Extrakt, $1 \% \mathrm{NaCl}$, nach Bedarf $50 \mu \mathrm{g} / \mathrm{ml}$ Ampicilin) kultiviert. Stammkulturen wurden langfristig in $40 \%$ Glycerin bei $\approx-70{ }^{\circ} \mathrm{C}$ gelagert. Für Zeiträume von Wochen wurden die Kulturen auch als einzelne Kolonien auf Agarplatten (80 ml LB-Medium mit 1\% Agar-Agar in steriler Petri-Schale mit $100 \mathrm{~mm}$ Durchmesser) bei $4{ }^{\circ} \mathrm{C}$ verwahrt. Bereits als kompetent gelieferte Zellen wurden nach Herstellerangaben gelagert. Übernachtkulturen wurden durch Beimpfen von meist $2 \mathrm{ml}$ LB-Medium in $15 \mathrm{ml}$ Reagenzgläsern aus Borsilikat (Schott, Mainz) oder Polypropylen 
(PP, Falcon, BD BIOSCIENCES, USA) mit einer Einzelkolonie und anschließender Inkubation bei $37^{\circ} \mathrm{C}$ und $225 \mathrm{Upm}$ in einem Schüttelinkubator für $12-16 \mathrm{~h}$ erzeugt.

\subsubsection{Xenopus laevis}

X. laevis (Anura) ist der in Südafrika beheimatete Krallenfrosch. Die Anzucht und die Präparation von Oozyten erfolgte nach GRYGORCZYK et al. (1989).

\subsection{Desoxyribonukleinsäuren (DNA)}

\subsubsection{Plasmide}

pUC19

Für die Klonierung von PCR-Produkten und Restriktionsfragmenten wurde der Klonierungsvektor pUC19 (MESSING, 1984, FERMENTAS GmbH, St. Leon-Rot) verwendet. Das Plasmid trägt eine multiple cloning site (MCS) innerhalb eines Teils von lacZ, einem Bestandteil des Lac-Operons von E. coli, dessen Translationsprodukt das $\alpha$ Peptid ist. Wird ein solches Plasmid in einen Stamm (z.B. XL1-blue) mit einer Mutation im lacZ-Gen gebracht, stellt dieses $\alpha$-Peptid die Funktion des Lac-Operons wieder her ( $\alpha$-Komplementierung, ULMANN et al., 1967). Ist das Gen allerdings durch eine Insertion in der MCS unterbrochen, bleibt die $\alpha$-Komplementierung fast immer aus, was im Zuge des sog. blue-white-screenings (HORWITZ et al., 1978) eine Unterscheidung zwischen Klonen mit leerem Plasmid und Klonen mit Insert in der MCS des Plasmids ermöglicht.

pSGEM

Für die Expression in Oozyten von $X$. laevis wurde ein rekombinantes Opsin-Gen (aopmut, s. 3.4.1.2) in den dafür geeeigneten Vektor pSGEM kloniert. pSGEM wurde von M. Hollmann (Max-Planck-Institut für Experimentelle Medizin, Göttingen) auf Grundlage von pGEM-HE konstruiert und großzügig zur Verfügung gestellt. 


\subsubsection{Oligonukleotide}

Aus 16-29 Nukleotiden bestehende Oligonukleotide dienten als Startmoleküle (primer) für die PCR und die reverse Transkription (RT). Mit der Herstellung von Oligonukleotiden wurden die Firmen Biometra (Göttingen), IBA GmbH (Göttingen), OPERON (Niederlande) und QIAGEN (Niederlande) betraut. Tabelle 1 zeigt die Nukleotidsequenzen der verwendeten Oligonukleotide.

Tabelle 1: Nukleotidsequenzen der verwendeten Oligonukleotide mit Verweis auf das jeweilige Kapitel

\begin{tabular}{|c|c|c|}
\hline Bezeichnung & Sequenz & Kapitel \\
\hline paoprt & 5 ' GCACGGCAAGCATGATGCAGCCGAC3 ' & 2.12 \\
\hline paopdetfw & 5 ' CGGATGAGCGTGAAGTTA3' & 3.1 \\
\hline paopdetrev & 5 ' TCAAGCAGTCAAAGGCTAAG3' & 3.1 \\
\hline ppolytpcr & 5 ' GACTCGAGTTTTTTTTTTTTTTTT3' & 3.2 .1 \\
\hline paop 5rpcr & 5 ' CCGTCGACGGTGAATGCGCCGATGATAC3 ' & 3.2 .1 \\
\hline ppolycpcr & 5 ' CAAGGAATTCCCCCCCCCCCCCC 3 ' & 3.2 .1 \\
\hline paopfufw & 5 ' ACCTGCAGATCTCACGTTCTGTA3' & 3.2 .2 \\
\hline paopfurev & 5 ' AGTCTAGAAAGGATGCTTGCAATATCA3 ' & 3.2 .2 \\
\hline M13 forward (-21) & 5' TGTAAAACGACGGCCAGT3' & 3.3 .1 \\
\hline M13 rev & 5 ' CAGGAAACAGCTATGACC3' & 3.3 .1 \\
\hline paopmutff & 5 ' CGCGGATCCATGTCAAACCCTAACCCT3' & 2.14.3, 3.4.1.2 \\
\hline paopmuta & 5 ' CGGCCGGAACTGAACAGCGATGGAA3 ' & 2.14.3, 3.4.1.2 \\
\hline paopmutsf & 5 ' TTCAAGCTTCCTCGAGCCCCAACTTTTCC3' & 2.14.3, 3.4.1.2 \\
\hline
\end{tabular}

\subsection{Elektronische Verarbeitung von DNA-Sequenzen}

Zur Verarbeitung und virtuellen Repräsentation von DNA-Sequenzen dienten die Computerprogramme Chromas Lite

(http://www.technelysium.com.au/chromas_lite.html) und pDraw (ACACLONE SOFTWARE).

Der softwaregestütze Vergleich von mehreren Aminosäurensequenzen (multiple sequence alignment) wurde mit den Programmen BioEdit (HALL, 1999), MEGA 
(KUMAR et al., 2004) und ClustalX (THOMPSON et al., 1997) auf Grundlage von Clustal (HIGGINS \& SHARP, 1988) ausgeführt.

Voraussagen der Topologie translatierter DNA entsprechende Proteine hinsichtlich der Ausbildung von TMHs wurden mithilfe des Dense-Alignment-Surface-Algorithmus (DAS, CSERZO et al (1997)) erzeugt, zugänglich auf dem DAS-TMfilter-Server (http://www.enzim.hu/DAS/DAS.html) und in Form des DAS-TMfilter prediction tools (Quellcode erhältlich unter http://www.enzim.hu/DAS/dis.tar.nc). Der DASAlgorithmus geht von perfekten (also ausschließlich aus hydrophoben Aminosäuren bestehenden) TMHs aus und vergleicht anhand einer empirisch ermittelten Gewichtungstabelle (scoring matrix) die Eingabedaten mit einer Bibliothek von bekannten, nicht homologen TMPen. Resultat ist eine Wertung (score) für jede Aminosäure, ein Maß für ihre Wahrscheinlichkeit, an einer TMH beteiligt zu sein. Als Vergleichsbibliothek wurde die größte verfügbare Bibliothek mit 32 Einträgen gewählt.

Es wäre interessant gewesen, Voraussagen zur Topologie und multiple sequence alignment automatisiert zu kombinieren, um der fehlenden Anpassung der zum multiple sequence alignment verwendeten scoring matrices an Besonderheiten der Sekundärstruktur (in diesem Falle von TMPen) Rechnung zu tragen. SHAFRIR \& GUY (2004) veröffentlichten eine solche Möglichkeit in Form des STAM-Algorithmus, der allerdings nicht verfügbar war.

Phylogenetische Zusammenhänge wurden mithilfe des Softwarepaketes MEGA (Version 1.3, KUMAR et al., 2004) untersucht.

Für Analysen der Codonverwendung (Codon-Usage) wurde der Codon Usage Analyser (SCHÖBEL B., www.gcua.de) herangezogen.

3D-Modelle von Proteinen wurden mithilfe des Programms DeepView/Swiss PdbViewer (GUEX \& PEITSCH, 1997, http://www.expasy.org/spdbv/) erstellt.

\subsection{Reinigung von Nukleinsäuren}

\subsubsection{Phenol/Chloroform-Extraktion}

Zur Entfernung verschiedener organischer Moleküle aus wässrigen 
Nukleinsäurelösungen wurden diese mit einem Gemisch aus Phenol, Chloroform und Isoamylalkohol (PCI, ROTH, Mannheim) in einem Volumenmischverhältnis von 25:24:1 behandelt. Für die Reinigung von DNA wurde der $\mathrm{pH}$ der Phenollösung vorher auf einen Wert von 8 gebracht. Dazu wurde sie mit 0,5 M Tris/HCl, pH 8 überschichtet, die beiden Phasen wurden für 15 min gemischt und die wässrige Phase nach erfolgter Phasentrennung entfernt. Das wurde noch zwei Mal wiederholt, bis der gewünschte $\mathrm{pH}$ erreicht war. Die äquilibrierte Lösung wurde für die Lagerung $\left({ }^{\circ} \mathrm{C}\right)$ mit $0,1 \mathrm{Vol} 0,1 \mathrm{M}$ Tris/HCl, pH 8 überschichtet.

Für die Reinigung von Nukleinsäuren wurden je nach Maßstab $2 \mathrm{ml}$ Reaktionsgefäße aus PP (EPPENDORF, Hamburg) oder $30 \mathrm{ml}$ Zentrifugenbecher aus Polyethylen verwendet. Der die Nukleinsäuren enthaltenden wässrigen Lösung wurde 1 Vol der jeweiligen PCI-Lösung zugesetzt und die Phasen durch Schütteln für 15 min gemischt. Für RNA-Lösungen wurde dabei ein automatischer Schüttler verwendet, während Lösungen mit genomischer DNA zur Vermeidung einer Fraktionierung durch Scherkräfte vorsichtig um die Längsachse des Röhrchens manuell rotiert wurden. Die Phasentrennung wurde abhängig vom Maßstab durch Zentrifugation in einer Tischzentrifuge (12.000 g, $10 \mathrm{~min}$, Raumtemperatur (RT) oder $4{ }^{\circ} \mathrm{C}$ ) oder einer Hochgeschwindigkeitszentrifuge (Rotor SS34 oder HB4 in SORVALL RC-5B, 5.000 g, $10 \mathrm{~min}, 4^{\circ} \mathrm{C}$ ) erreicht. Die wässrige Phase wurde abgenommen und die PCI-Phase mit der auf hohen Proteinanteil zurückzuführenden Zwischenphase verworfen. Generell wurde diese Prozedur bis zum Verschwinden der Zwischenphase wiederholt. Zur Entfernung von in der wässrigen Phase verbliebenem Phenol wurde abschließend 1 Vol Chloroform/Isoamylalkohol zugesetzt und im weiteren wie mit PCI verfahren.

\subsubsection{Fällung von Nukleinsäuren}

Ebenfalls zur Entfernung von verschiedenen organischen Molekülen und zur Konzentrierung von Nukleinsäurelösungen wurden Nukleinsäuren durch Zugabe von 0,1 Vol 3 M NaAcetat, pH 5,3, und 2,5 Vol Ethanol, $97 \%$, und anschließende Inkubation $\left(1 \mathrm{~h},-20^{\circ} \mathrm{C}\right)$ gefällt, je nach Maßstab in 1,5 oder $2 \mathrm{ml}$ Reaktionsgefäßen oder in 15/50 ml Zentrifugenröhrchen aus PP (Falcon, BD BIOSCIENCES). Die Rückgewinnung der Nukleinsäuren erfolgte je nach Maßstab durch Zentrifugation in einer Tischzentrifuge $\left(12.000 \mathrm{~g}, 4{ }^{\circ} \mathrm{C}\right)$ oder einer Hochgeschwindigkeitszentrifuge 
(SORVALL GSA-Rotor in SORVALL RC-5B, $20 \mathrm{~min}, 5.000 \mathrm{~g}, 4{ }^{\circ} \mathrm{C}$ ). Das Pellet wurde mit 1,5 Ausgangsvolumen Ethanol, $70 \%$, gewaschen und erneut zentrifugiert. Der Überstand wurde sehr sorgfältig abgenommen und das Pellet bei RT für 10 min $2 \mathrm{~h}$ getrocknet. Danach wurde es je nach Verwendungszweck in $\mathrm{H}_{2} \mathrm{O}$ bidest. oder TEPuffer (10 mM Tris/HCL, pH 7,4, 1mM EDTA) gelöst. So spielt die Wirkung von EDTA als Chelator von zweiwertigen Kationen nur für DNA eine Rolle. DNasen sind ohne $\mathrm{Mg}^{2+}$ inaktiv, was in DNA-Lösungen erwünscht ist. RNasen sind in ihrer Aktivität $\mathrm{Mg}^{2+}$-unabhängig.

\subsubsection{Reinigung von DNA mithilfe von Silicagel-Membran-}

\section{Säulen}

Die Standard-Reinigung von Plasmid-DNA und PCR-Produkten wurde mit dem QiaQuick PCR Purification Kit oder im Fall kritischer Nukleinsäurekonzentration mit dem MinElute PCR Purification Kit (beide QIAGEN) vorgenommen.

\subsection{Konzentration und Reinheit von Nukleinsäuren in Lösungen}

Zur Konzentrationsbestimmung von Nukleinsäuren in wässrigen Lösungen wurde deren Absorption ultravioletten (UV) Lichts ausgenutzt, die mit einem Photometer (Genequant II, PHARMACIA, Freiburg) gemessen wurde. Eine optische Dichte bei 260 $\mathrm{nm}\left(\mathrm{OD}_{260}\right)$ von 1 bei einer Schichtdicke von $1 \mathrm{~cm}$ wurde mit einer Konzentration von $50 \mu \mathrm{g} / \mathrm{ml}$ für doppelsträngige DNA (dsDNA) oder $40 \mu \mathrm{g} / \mathrm{ml}$ für Ribonukleinsäure (RNA) gleichgesetzt. Verunreinigung der Probe mit Proteinen wurden toleriert, wenn $\mathrm{OD}_{260} / \mathrm{OD}_{280}>1.8(\mathrm{dsDNA})$ oder $>2,0(\mathrm{RNA})$ gemessen wurde.

\subsection{Auftrennung von Nukleinsäuren im elektrischen Feld}

Gelelektrophorese wurde zur analytischen Auftrennung von RNA als auch von DNA sowohl $\mathrm{zu}$ analytischen als auch $\mathrm{zu}$ präparativen (2.6.1) Zwecken verwendet. Agarosegele wurden in Flachbettkammern aus Plexiglas (Schichtdicke $4 \mathrm{~mm}$, Eigenbau; 
Schichtdicke $15 \mathrm{~mm}$, BIOMETRA, Göttingen) hergestellt. Dazu wurde Agarose (SEAKEM LE Agarose, CAMBREX, USA) in Konzentrationen von 0,8 - 2,0 \% (w/v) in einem Mikrowellenofen bis zur vollständigen Solubilisierung in TBE-Puffer (45 mM Tris Base, $45 \mathrm{mM}$ Borsäure, 2,5 mM EDTA, pH 8) oder TAE-Puffer (40 mM Tris Base, 40 mM Essigsäure, 1 mM EDTA, pH 8) erhitzt. Nach Abkühlung auf ca. $50{ }^{\circ} \mathrm{C}$ wurde Ethidiumbromid in einer Endkonzentration von $0,5 \mu \mathrm{g} / \mathrm{ml}$ zugesetzt und die Mischung in die Kammern gegossen. Das erstarrte Gel wurde mit TBE-Puffer bedeckt und die mit Auftragspuffer (FERMENTAS, 6 X) vermischten Proben in die Auftragstaschen (25 $50 \mu 1)$ pipettiert. Die Auftrennung der Nukleinsäuren erfolgte dann im elektrischen Feld bei 6-8 V/cm. Als Längenstandard wurde O'RangeRuler 500bp+1000bp DNA-Ladder (FERMENTAS) oder TriDye $100 \mathrm{bp}$ ladder (NEW ENGLAND BIOLABS, USA) verwendet.

Um den DNA- bzw. RNA-Ethidiumbromid-Komplex sichtbar zu machen, wurde das Agarosegel auf einem UV-Leuchttisch (PHARMACIA, Freiburg, LKB 2011 MACP Transillumin, $305 \mathrm{~nm}$ ) durchstrahlt und gegebenenfalls zur Dokumentation fotografiert (DS-34 Direct Screen Instant Camera, POLAROID; Camedia 2000 Digitalkamera, OLYMPUS, Japan).

\subsubsection{Isolierung von DNA aus Agarosegelen}

Die im Agarosegel lokalisierten DNA-Fragmente wurden mit einem Skalpells ausgeschnitten und mit dem MinElute Gel Extraktion Kit (QIAGEN) nach Herstellerangaben extrahiert.

\subsection{Enzymatische Spaltung und Verknüpfung von DNA}

\subsubsection{Fragmentierung von DNA mit Endonukleasen}

Im Rahmen von Klonierungen und zur Charakterisierung unbekannter DNA-Fragmente (Restriktionsanalysen) wurden Restriktionsendonukleasen des Typs II der Fa. FERMENTAS nach deren Angaben verwendet. Standard-Spaltungen wurden mit 5-10 U des Enzyms pro $\mu \mathrm{g}$ DNA durchgeführt und dauerten $60 \mathrm{~min}$. Die Reaktion wurde durch Hitzineaktivierung bei für die jeweiligen Enzyme empfohlenen Temperaturen 
zwischen 60 und $80{ }^{\circ} \mathrm{C}$ für $10 \mathrm{~min}$ unterbrochen. Zur weiteren enzymatischen Behandlung wurden die Reaktionsgemische einer Reinigung nach 2.4.3 unterzogen.

\subsubsection{Ligation von DNA-Fragmenten}

Nach 2.7.1 gewonnene Restriktionsfragmente wurden mithilfe von T4-DNA-Ligase (FERMENTAS) mit ebenfalls durch Restriktionsenzyme verdauter Vektor-DNA in einem Volumen von $20 \mu \mathrm{l}$ nach Maßgabe des Herstellers zu rekombinanten Plasmiden verknüpft, welche nach Transformation (2.8) beliebig vervielfältigt werden können (Klonierung). Die Ligation fand nach Maßgabe des Herstellers in einem Volumen von $20 \mu 1$ statt. Es wurden 5 Weiss-units pro $\mu \mathrm{g}$ DNA eingesetzt.

\subsection{Transformation von E. coli}

Die Transformation bereits kompetenter Zellen des Stammes XL1-blue (XL1-Blue Supercompetent Cells, STRATAGENE) wurde nach dem jeweils mitgelieferten Protokoll durchgeführt. 10-100 ng experimenteller DNA wurden der Bakteriensuspension in einem Volumen von $10 \mu \mathrm{l}$ zugefügt. Als Positivkontrolle dienten 50 ng pUC19-DNA in einem Volumen von $1 \mu$ l. Der sog. heat shock wurde den Zellen für $50 \mathrm{~s}$ bei $42^{\circ} \mathrm{C}$ in einem temperaturgeregelten Wasserbad versetzt.

Zur Überführung gewöhnlicher Übernachkulturen in den Zustand der Kompetenz und zur anschließender Transformation wurde das TransformAid Bacterial Transformation Kit der Fa. FERMENTAS verwendet. Statt der empfohlenen 1,5-ml-Reaktionsgefäße wurden wie für die kompetenten Zellen der Fa. STRATAGENE Reagenzgläser aus PP (15 ml, Falcon, BD BIOSCIENCES) verwendet.

\subsection{1 blue-white-screening}

War blue-white-screening auf Grundlage der $\alpha$-Komplementierung (2.2.1) möglich, wurden zu diesem Zwecke geeignete Agarplatten mit sGAL und IPTG (sGAL-Agar, SIGMA-ALDRICH Inc., USA; $50 \mu \mathrm{g} / \mathrm{ml}$ Ampicilin) nach Angaben des Herstellers angefertigt und verwendet. Positive Klone wurden anhand fehlender Schwarzfärbung oder geringer Schwarzfärbung im Zentrum der Kolonie identifiziert, mithilfe einer 
abgeflammten Impföse isoliert und als Übernachtkultur in Gegenwart von Ampicilin kultiviert.

\subsection{Präparation von Plasmid-DNA aus E. coli}

Zur Präparation von Plasmiden aus E. coli wurde das QiaPrep Spin Miniprep Kit (QIAGEN) nach Herstellerangaben eingesetzt.

\subsection{Sequenzierung von DNA}

Die Fa. SEQLAB (Göttingen) führte die Sequenzierung von PCR-Produkten und inserts von Plasmiden durch. Die dazu nötigen primer waren bei SEQLAB vorrätig oder wurden vom Autor bereitgestellt.

\subsection{Präparation von RNA}

Für die Arbeiten mit RNA wurden zur Vermeidung einer Degradation durch RNasen besondere Maßnahmen ergriffen. So wurden Geräte aus Glas oder Stahl ü.N. bei $180{ }^{\circ} \mathrm{C}$ gehalten und solche aus Kunststoff in RNase-freiem Zustand erworben (Reaktionsgefäße, Pipettenspitzen, EPPENDORF; Zentrifugenröhrchen aus PP, $15 \mathrm{ml}$ und $50 \mathrm{ml}$, Falcon, BD BIOSCIENCES). Alle anderen Materialien, die nicht in direkten Kontakt mit RNA, wohl aber in unmittelbare Nähe gerieten (Handschuhe, Mikroliterpipetten, Reaktionsgefäßständer, Arbeitsplatte), wurden regelmäßig mit einem RNase-Dekontaminationsmittel (RNase $A W A Y$, NBP BIOPRODUCTS, USA) behandelt und verblieben an einem für Arbeiten mit RNA reservierten Arbeitsplatz. Wässrige Lösungen wurden, soweit sie keine Substanzen mit freien Aminogruppen enthielten (Tris), ü.N. mit Diethylpyrocarbonat (DEPC, FEDORCSAK \& EHRENBERG, 1966) behandelt $(0,1 \quad \% \quad(\mathrm{v} / \mathrm{v}))$ und anschließend autoklaviert, enzymatische Reaktionsgemische enthielten zusätzlich einen RNase-Hemmstoff (RiboLock, FERMENTAS). RNA enthaltende Lösungen wurden bei $\approx-70{ }^{\circ} \mathrm{C}$ gelagert und, soweit sinnvoll, im Zuge experimenteller Handhabung bei Temperaturen um $0{ }^{\circ} \mathrm{C}$ gehalten. 


\subsubsection{Extraktion von Gesamt-RNA aus $A$. acetabulum}

Zellen von 5 - 12 mm Länge wurden geerntet, indem der Inhalt der Kulturschalen (2.1.1) über einem Nylonnetz entleert und die dort festgehaltenen Zellen mit 11 künstlichem Meerwasser gewaschen wurden. Nach Entfernen eines Großteils der Flüssigkeit durch sanften Druck mit einer stumpfen Pinzette wurde das Frischgewicht der Zellen bestimmt. Die Zellen wurden in haselnußgroßen Portionen in flüssiges $\mathrm{N}_{2}$ überführt und im Bedarfsfall bis zur Verwendung bei $\approx-70^{\circ} \mathrm{C}$ gelagert.

Die gefrorenen Zellen wurden nach Zugabe von $\sim 1 / 10$ Vol gereinigtem, sterilisiertem Sand mit einem Stößel in einem Mörser zu einem feinen Pulver zerrieben, welches in einem Reaktionsgefäß aus PP (EPPENDORF) mit 3 Vol Extraktionspuffer (100 mM LiCl, $100 \mathrm{mM}$ Tris/HCl pH 8.0, $10 \mathrm{mM}$ EDTA, 1\% $\beta$-Mercaptoethanol) vermischt wurde. Darauf folgte eine Phenol/Chloroform-Extraktion (2.4.1). Die Extraktion mit CI wurde dabei durch 60 min langes Schwenken auf einer maschinellen Wippe statt durch Schütteln vorgenommen. Die wässrige Phase wurde mit 1/4 Vol $8 \mathrm{M} \mathrm{LiCl} \mathrm{vermischt} \mathrm{und}$ die RNA ü.N. bei $4{ }^{\circ} \mathrm{C}$ gefällt. Das Präzipitat wurde durch Zentrifugation (12.000 g, 10 min, $4{ }^{\circ} \mathrm{C}$ ) sedimentiert. Das Sediment wurde nacheinander mit $500 \mu 12 \mathrm{M} \mathrm{LiCl}$ und mit $500 \mu \mathrm{l}$ Ethanol gewaschen und jeweils unter gleichen Bedingungen zentrifugiert. Nach 15 - 30 min Lufttrocknung bei $0{ }^{\circ} \mathrm{C}$ wurde es in $20 \mu 1$ mit DEPC behandeltem $\mathrm{H}_{2} \mathrm{O}$ gelöst.

\subsubsection{Isolierung von messenger-RNA (mRNA)}

Gelegentlich lieferten die unter 2.14 und 2.14.1 beschriebenen Methoden mit aus Gesamt-RNA erzeugter cDNA als template kein zufriedenstellendes Ergebnis. Mit dem Ziel der Konzentration des targets sollte deshalb die mRNA, als jenes enthaltene Fraktion der RNA, isoliert werden. Die mRNA unterscheidet sich auf struktureller Ebene von den übrigen RNA-Spezies unter anderem durch ihr uniformes 3'-Ende, das aus 60-200 Adenylaten besteht. Der Einsatz von kovalent an Cellulose gebundene Oligomere von Desoxytymidylat (Oligo-dT-Cellulose, BIOMOL, Hamburg) als Affinitätsagens nutzt diese Eigenschaft zur Trennung der polyA-RNA von den übrigen RNA-Spezies aus.

Die Oligo-dT-Cellulose wurde zunächst jeweils $2 \mathrm{~h}$ nacheinander in verschiedenen 
Lösungen gewaschen (1mM EDTA pH 7,5; 0,1 M NaOH, 5 mM EDTA; 1 mM EDTA; TE-Puffer), abzentrifugiert (7000 Upm, $2 \mathrm{~min}$ ) und schließlich in $10 \mathrm{Vol}$ Bindungspuffer (BB, $40 \mathrm{mM}$ Tris/ $\mathrm{HCl}, 1 \mathrm{M} \mathrm{NaCl}, 2 \mathrm{mM}$ EDTA, 0,2\% Naduodecylsulfat (SDS), pH 7,5) wieder aufgenommen.

Zur Bindung der mRNA wurden $20 \mu$ der zuvor gewonnenen RNA-Lösung (2.11.1) mit $20 \mu \mathrm{l}$ der gewaschenen Oligo-dT-Cellulose und $40 \mu \mathrm{BB}$ vermischt und für 3 min bei $70{ }^{\circ} \mathrm{C}$ inkubiert, danach für 10 min geschüttelt (EPPENDORF Thermomixer Comfort) und zentrifugiert (7000 Upm, $2 \mathrm{~min}$ ). Nach dreimaligem Waschen mit 0,5 X BB wurde das Pellet von restlicher Flüssigkeit befreit, in $20 \mu \mathrm{l}$ 1mM EDTA resuspendiert und die mRNA 1 min bei $70{ }^{\circ} \mathrm{C}$ eluiert. Nach Zentrifugation (7000 Upm, 2 min) wurde der Überstand separiert und die Elution zwei Mal wiederholt. Die gereinigte mRNA wurde aus dem vereinigten Überstand wie beschrieben (2.4.2) gewonnen.

\subsection{Synthese komplementärer DNA (cDNA)}

Da für PCR verwendete DNA-Polymerasen keine RNA-abhängige Polymeraseaktivität besitzen, musste zur spezifischen Vervielfältigung von Transkripten die mRNA mithilfe reverser Transkriptase, einer von Retroviren kodierten, RNA-abhängigen DNAPolymerase, in komplementäre DNA (cDNA) übersetzt werden. Dazu wurde das RevertAid H Minus First Strand cDNA Synthesis Kit (FERMENTAS) nach Herstellerangaben verwendet. Dieses Komplettpaket enthält eine reverse Transkriptase aus dem Molony Murine Leukemia Virus (M-MuLV). Für die Übersetzung des kompletten mRNA-Bestands in cDNA wurde wieder (s. 2.11.2) das poly-dA-Ende der mRNA ausgenutzt und ein Oligo-dT-primer eingesetzt $\left(\mathrm{T}_{16}\right)$, der mit den Adenylatresten des 3'-Endes der mRNA hybridisieren sollte. Für die Synthese sequenzspezifischer cDNA im Zuge der 5'-RACE wurde der spezifische primer paoprt verwendet.

Als template wurden 0,2-2 $\mu \mathrm{g}$ Gesamt-RNA oder die aus $2 \mu \mathrm{g}$ Gesamt-RNA isolierte mRNA verwendet. Die Ausbeute konnte nicht bestimmt werden, der Erfolg wurde jedoch jeweils funktional anhand der nachfolgenden enzymatischen Vervielfältigung von Transkripten $(2.14,2.14 .1)$ nachgewiesen. 


\subsection{Erzeugung homopolymerer DNA-Enden (homopolymeric tailing)}

Um für 5'-RACE (2.14.1) auf der 3'-Seite der cDNA (entspricht der 5'-Seite der mRNA, s. ebd.) eine Sequenz zum Anheften (annealing) eines primers zu generieren, wurde ein Homopolymer von Cytosinen (polyC-tail) angehängt (ESCHENFELDT et. al, 1987). Dazu wurde terminale Desoxynukleotidyl-Transferase (TdT, FERMENTAS) nach Angaben des Herstellers verwendet. TdT ist eine template-unabhängige Polymerase, die in Anwesenheit von nur einem Mononukleotid (in diesem Falle Cytosin) ein Homopolymer an das 3'-Ende von DNA fügt. Als primer dient im vorliegenden Fall die komplementäre mRNA, welche zuvor als template zur cDNA-Synthese (2.12) diente. Nach einer Reinigung (2.4.3) wurde die gesamte nach 2.12 erzeugte cDNA und dCTP der Fa. ROCHE DIAGNOSTICS (Mannheim) als Substrat verwendet.

\subsection{Polymerasekettenreaktion (PCR)}

PCR (SAIKI et al., 1985, MULLIS \& FALOONA., 1987) wurde zur Vervielfältigung von Opsinsequenzen aus A. Acetabulum $(2.14 .1,2.14 .3)$ und für die Mutagenese bereits klonierter Gene (2.14.3) verwendet. PCR wurde in 0,2 ml-Gefäßen mithilfe eines Thermocyclers der Fa. BIOMETRA durchgeführt. Dabei wurden verschiedene Maßnahmen zur Verhinderung von Kontaminationen der PCR-Reaktionen mit vorher erhaltenen PCR-Produkten ergriffen. So wurden alle Pipettierarbeiten innerhalb einer Sterilbank verrichtet, die Pipettenspitzen waren mit Aerosolfiltern versehen. Eine ausführliche Besprechung der Laborpraxis für die PCR ist bei ORREGO (1990) zu finden.

Je nach Anwendung wurden thermostabile Polymerasen (SAIKI et al., 1988) mit unterschiedlichen Eigenschaften bezüglich Fehlerrate (CLINE et al., 1996), Möglichkeit einer Hitzeaktivierung (hot start, D'AQUILA et al., 1991) und Arbeitsaufwand bei der Durchführung verwendet.

Die Abfolge der einzelnen Reaktionsschritte folgte, wenn nicht anders angegeben, nachstehendem Schema:

1. Anfängliche Denaturierung bei $95^{\circ} \mathrm{C}$ für $2 \mathrm{~min}$ 
2. 25 - 35 Zyklen, bestehend aus

a) Denaturierung bei $95^{\circ} \mathrm{C}$ für $30 \mathrm{~s}$

b) annealing (Anheften der primer) für $30 \mathrm{~s}$ bei $T_{A}$

c) Elongation bei $72{ }^{\circ} \mathrm{C}$ für $1 \mathrm{~min} / \mathrm{kb}$ target-Länge

3. Abschließende Elongation für $10 \mathrm{~min}$

Die annealing-Temperatur $T_{A}$ wurde dabei $5{ }^{\circ} \mathrm{C}$ unter der Schmelztemperatur $T_{M}$ der primer gewählt $\left(T_{A}=T_{M}-5^{\circ} C\right)$. Zur Ermittlung von $T_{M}$ wurde von der empirischen Beziehung

$$
T_{M}=2\left(N_{A}+N_{T}\right)+4\left(N_{G}+N_{C}\right)
$$

mit $N_{X}=$ Anzahl des jeweiligen Nukleotids im primer ausgegangen.

Für analytische Standardvervielfältigungen kam PCR Master Mix (PROMEGA, USA) zum Einsatz. $50 \mu \mathrm{l}$ Ansatz enthielten $25 \mu \mathrm{l}$ PCR Master Mix, jeweils $1-2 \mu \mathrm{M}$ spezifische primer und 0,1-100 $\mathrm{mM}$ template.

Zum Zwecke der Ermittlung unbekannter Abschnitte von als cDNA vorliegender mRNA wurde AmpliTaq-Gold-Polymerase (APPLIED BIOSYSTEMS, USA) eingesetzt. AmpliTaq-Gold-Polymerase ist zunächst inaktiv und muß durch Wärmeeinwirkung aktiviert werden. Durch einen anfänglichen Aktivierungsschritt (10 min bei $95{ }^{\circ} \mathrm{C}$ ) wird so ein automatischer hot start (D'AQUILA et al., 1991) zur Vermeidung unerwünschter unspezifischer Bindung der primer an das template (mispriming) und primer-Dimerisierung ermöglicht. Das vorstehende Schema änderte sich somit wie folgt:

1. Anfängliche Denaturierung/Aktivierung der Polymerase für $10 \mathrm{~min}$

$50 \mu$ Reaktionsansatz enthielten 1 X GeneAmp $10 X$ PCR buffer II, je $1 \mu \mathrm{M}$ des senseund des antisense-primers, $200 \mu \mathrm{M}$ jedes Mononukleotids, $2 \mathrm{mM} \mathrm{MgCl}_{2}$ und 1,5 $\mathrm{U}$ AmpliTaq-Gold-Polymerase. Das template wurde in einem Volumen zwischen 5 und $10 \mu \mathrm{l}$ zugefügt und enthielt so jeweils die halbe bis komplette Ausbeute der nach 2.12 erhaltenen cDNA. 


\subsubsection{Vervielfältigung unbekannter cDNA-Enden (Rapid Amplification of cDNA-Ends (RACE))}

Die unbekannten 3'- und 5-Enden einer mRNA wurde nach dem Prinzip von FROHMANN et al. (1988) ermittelt. Es handelt sich im Falle von 3'-RACE nicht um die Vervielfältigung des 3'-Endes, sondern des 5'-Endes der cDNA, die aber komplementär zu dem gesuchten 3'-Ende der jeweiligen mRNA ist. Der im Fachjargon übliche Begriff 3'-RACE und sein Analogon 5'-RACE sind somit irreführend, bezieht sich die Benennung der Enden doch auf die mRNA und nicht, wie der Name suggeriert, auf die cDNA, deren Enden tatsächlich vervielfältigt werden.

Zur Ermittlung des 3'-Endes einer mRNA wurde die mithilfe eines Oligo-dT-primers (FERMENTAS) synthetisierte cDNA (2.12) gereinigt (2.4.3, Elutionsvolumen $9 \mu \mathrm{l}$ ) und in einer nachfolgenden PCR als template eingesetzt. Zur Erhöhung der Spezifität wurde bei Bedarf im touchdown-Modus (DON et al., 1991) verfahren, d. h. $T_{A}$ wurde von einem anfänglich höheren Wert schrittweise auf $T_{M}-5^{\circ} C$ erniedrigt. Die Zeit- und Temperaturparameter waren wie folgt:

1. Anfängliche Denaturierung/Aktivierung der Polymerase bei $95{ }^{\circ} \mathrm{C}$ für $10 \mathrm{~min}$

2. 34 Zyklen, bestehend aus

a) Denaturierung bei $95^{\circ} \mathrm{C}$ für $1 \mathrm{~min}$

b) annealing bei experimentell ermittelten Temperaturen für 1 min;

$\Delta T / \Delta N=-1^{\circ} \mathrm{C} \quad$ (bedarfsweise)

c) Elongation bei $72{ }^{\circ} \mathrm{C}$ für $1 \mathrm{~min} 30 \mathrm{~s}$

3. Abschließende Elongation bei $72{ }^{\circ} \mathrm{C}$ für $7 \mathrm{~min}$

Die Vervielfältigung des 5'-Endes einer mRNA erfolgte analog, als template diente statt der mit einem Oligo-dT-primer erzeugten cDNA solche, deren Synthese mithilfe eines spezifischen primers stattfand (2.12) und deren 3'-Ende mit einem polyC-tail versehen wurde (2.13). 


\subsubsection{Erzeugung von Genklonen voller Länge}

Wegen der größeren Länge der Amplicons (- $1 \mathrm{~kb})$ und der damit verbundenen höheren Fehlerwahrscheinlichkeit wurde PfuUltra-Polymerase (STRATAGENE) als Polymerase mit der geringsten Fehlerrate (CLINE et al., 1996) für die Vervielfältigung vollständiger cDNAs und deren Mutagenese verwendet. Das Protokoll gab folgende Parameter vor:

1. Anfängliche Denaturierung und Aktivierung bei $95{ }^{\circ} \mathrm{C}$ für $8 \mathrm{~min}$

2. 35 Zyklen, bestehend aus

a) Denaturierung bei $96,5^{\circ} \mathrm{C}$ für $45 \mathrm{~s}$

b) annealing (Anheften der primer) für $1 \min 45 \mathrm{~s}$

c) Elongation bei $72{ }^{\circ} \mathrm{C}$ für $3 \min 15 \mathrm{~s}$

3. Terminale Elongation für $12 \mathrm{~min}$

\subsubsection{Mutagenese}

Da Acetabularia einen genetischer Code benutzt, der von dem als Standard betrachteten Code abweicht (vgl. OSAWA et al. (1992)), musste vor einer heterologen Expression in Organismen, die den Standard-Code verwenden (in diesem Fall $X$. laevis), eine Mutagenese hinsichtlich der abweichenden Basen-Tripletts stattfinden.

Die hier angewandte Methode der Megaprimer-PCR von KAMMANN et al. (1989) besteht im ersten Schritt in der Erzeugung eines sog. megaprimers durch eine PCR mit einem die zu vervielfältigende Sequenz flankierenden primer (erster flankierender primer, hier paopmutff) und einem mutagenen primer (hier: paopmuta). Dieser nun die gewünschte Mutation tragende megaprimer wird nach seiner Isolierung in einer zweiten PCR zusammen mit dem zweiten flankierenden primer (paopmutfs) zur Vervielfältigung der gesamten Sequenz verwendet.

Wegen des geringeren Arbeitsaufwandes kam das von TYAGI et al. (2004) vorgeschlagene Protokoll zum Einsatz, welches durch geschickte Vorgabe der primerKonzentration eine Gelisolation des megaprimers überflüssig macht. 


\subsection{Heterologe Expression in X. laevis}

\subsubsection{In-vitro-Transkription}

Um im heterologen System eine Expression eines Gens zu erhalten, wurde es mithilfe des mMessage mMachine T7 Ultra Kit (AMBION, USA) in vitro transkribiert. Als template für die Transkiption diente pSGEM-aopmut2 (3.4.1.2).

\subsubsection{Präparation und transiente Transformation der Oozyten}

Die Oozyten wurden nach GRYGORCZYK et al. (1989) präpariert. Pro Oozyte wurde 25 ng aopmut-cRNA injiziert. Anschließend wurden die Oozyten 4-6 Tage im Dunkeln bei $18^{\circ} \mathrm{C}$ in OR1-Lösung (96 mM NaCl, $5 \mathrm{mM} \mathrm{KCl}, 1 \mathrm{mM} \mathrm{MgCl} 2,2 \mathrm{mM} \mathrm{CaCl}, 5 \mathrm{mM}$ MOPS-NaOH, pH 7.5; mit $1 \mathrm{mg} / \mathrm{ml}$ Penicillin, $1 \mathrm{mg} / \mathrm{ml}$ Streptomycin und $1 \mathrm{mM}$ alltrans-Retinal) inkubiert.

\subsection{Elektrophysiologie}

Für die Durchführung von Two electrode voltage clamp wurden die Signalverstärker GeneClamp 500 (AXON INSTRUMENTS Inc., USA) oder Turbo-Tec-03X (NPI ELECTRONIC GmbH, Tamm) eingesetzt. Die Steuerung der Parameter und die Datenaufnahme (sampling rate $=50 \mathrm{kHz}$ ) und -verarbeitung übernahm das Computerprogramm pCLAMP 9.0 (AXON INSTRUMENTS Inc.). Als Lichtquelle diente eine Xenon-Lichtbogenlampe der Fa. OSRAM GmbH (München; Xenon short arc photo optic lamp, 1 x XBO 75 W/2 OFR). Zur Erzeugung monochromatischen Lichts wurden Interferenzfilter mit einer Bandbreite von $30 \mathrm{~nm}$ eingesetzt. Die verwendeten Mikroelektroden wurden mithilfe des micropipette pullers P-97 (SUTTER INSTRUMENTS, USA) aus Borosilikatkapilaren mit 1,5 mm Durchmesser hergestellt und mit 3 M KCl-Lösung gefüllt. Die Widerstände der Elektroden lagen zwischen 0,5 und $2 \mathrm{M} \Omega$.

Für die voltage-clamp-Messungen lagen die Oozyten in OR1-Lösung.Zur Erniedrigung des $\mathrm{pH}$ im Innern der Oozyte $\left(\mathrm{pH}_{\mathrm{i}}\right)$ von ursprünglich 7,3 auf 6,8 enthielt die Badlösung 40 mM Natriumbutyrat (STEWART et al., 2001). Die Lösung enthielt außerdem 56 mM 
statt $96 \mathrm{mM} \mathrm{NaCl}$.Hoher $\mathrm{pH}\left(\mathrm{pH}_{\mathrm{o}}\right.$ 10) im Außenmedium wurde mit $5 \mathrm{mM}$ Glycin gepuffert, niedriger $\mathrm{pH}_{\mathrm{o}}(4 ; 6)$ mit $5 \mathrm{mM}$ Citrat. Zur Untersuchung des Einflusses der $\mathrm{Na}^{+}$-Konzentration enthielt die Badlösung N-Methyl-n-Glucamin-Cl (NMGCl) statt $\mathrm{NaCl}$.

Zur Untersuchung des Einflusses der $\mathrm{Cl}^{-}$-Konzentration enthielt die Badlösung Natriumacetat statt $\mathrm{NaCl}$.

Zur Messung des elektrischen Stroms über die Oozytenmembran wurde nach Einstechen der Elektroden in die Oozyten eine Haltespannung von $-40 \mathrm{mV}$ vorgegeben. Haltespannungen der gewünschten Höhe wurden dann in $20-\mathrm{mV}$-Schritten angelegt. Es wurde gewöhnlich ein Mittelwert aus drei Experimenten verwendet. 


\section{Ergebnisse}

\subsection{Nachweis eines Opsin-Transkripts in Acetabularia acetabulum}

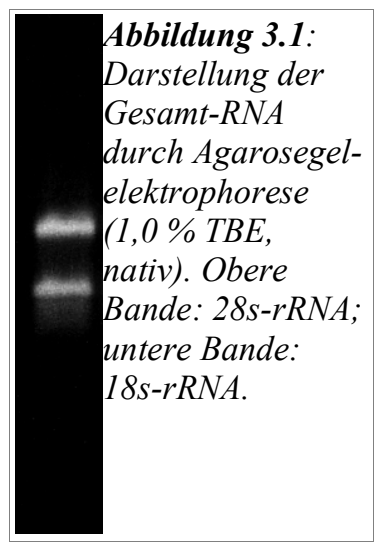

Abb. 3.1 zeigt die aus A. acetabulum isolierte Gesamt-RNA, welche nach Agarosegelelektrophorese das charakteristische Muster aus zwei primären Banden zeigt, welche 28sund 18s-ribosomale-RNA (rRNA) repräsentieren. Das Fehlen eines diffusen Bereiches zwischen den beiden Hauptbanden und unter der 18srRNA-Bande wurde als Indiz für den intakten Zustand der RNA ohne Kontamination durch RNAsen gewertet. Die RNA wurde für RT-PCR verwendet, um zunächst ein Teilstück der von HENRY et al. (2004) als Teil eines Opsin-Gen-Transkripts publizierten Sequenz zu vervielfältigen.

Das Ergebnis ist in Abb. $3.2 \mathrm{zu}$ sehen. Die nach der bisherigen Sequenzinformation zu erwartende Bande bei $\approx 500 \mathrm{bp}$ ist in

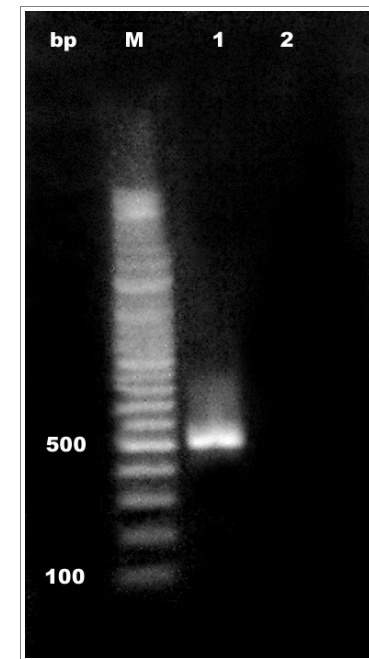

Abbildung 3.2:

Darstellung von RT$P C R$ mit PCR-primern paopdetfw und paopdetrev und (1) aus RNA juveniler Zellen (Abb. 3.1) hergestellter cDNA als template der PCR und (2) RNA juveniler Zellen statt cDNA. M: Längenstandard. Spur 1 zu finden, während die Negativkontrolle (Spur 2), bei der die reverse Transkription ausgelassen wurde, negativ ausfällt. Eine Bande in diesem Bereich hätte Kontamination der RNA-Probe mit genomischer DNA angezeigt. Das Amplifikat wäre in diesem Fall genomischen Ursprungs. So ist das Transkript eines möglichen Opsingens (Acetabularia-Opsin, im Weiteren aop) in juvenilen Zellen von $A$. acetabulum bestätigt. 


\subsection{Klonierung von aop}

\subsubsection{RACE}

Um die fehlende Sequenzinformation in 3'- und in 5'-Richtung von dem in Abb. 3.2
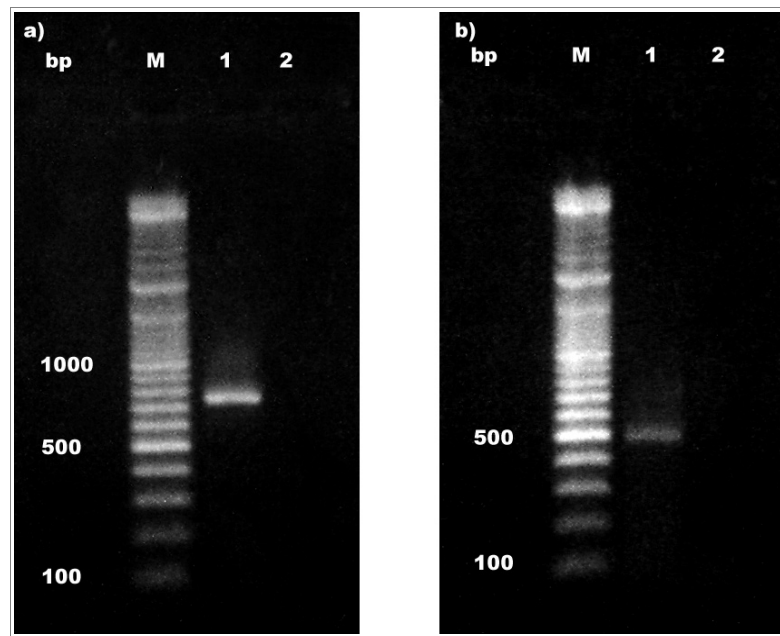

Abbildung 3.3: Darstellung von 3'-RACE und 5'-RACE von aop. $M$ : Längenstandard. a) 3'RACE mit $P C R$-primern paopdetfw und ppolytpcr; 1: Experiment mit Gesamt-RNA juveniler Zellen als template der RTReaktion; 2: Kontrolle ohne RNA.

b) 5'RACE mit PCR-primern paop5rpcr und ppolycpcr ; 1: Experiment mit polyA-RNA juveniler Zellen als template der RT-Reaktion; 2: Kontrolle ohne RNA. gezeigten Teilstück zugänglich zu machen, wurden 3'- und 5'-RACE eingesetzt.

Die Ergebnisse sind in Abb. $3.3 \mathrm{zu}$ sehen. Die Banden wurden ausgeschnitten, die enthaltene DNA gereinigt und sequenziert. Abb. 3.4 zeigt die Sequenz des gesamten Transkripts. Sie enthält im Vergleich mit der Sequenz von HENRY et al. (2004) ein 300 bp langes 5'-Ende, welches sechs als Initiationssignal für die Translation in Betracht kommende Codons (ATG) enthält. Das 3'-Ende stimmt mit der schon bekannten

Sequenz bis auf einzelne Basen (776: A, Insertion; 840 u. 845: T für A; 1003: A, Insertion) überein, der polyA-tail folgt direkt auf die letzte publizierte Base, ein Detail, das von HENRY et al. nicht erwähnt wird.

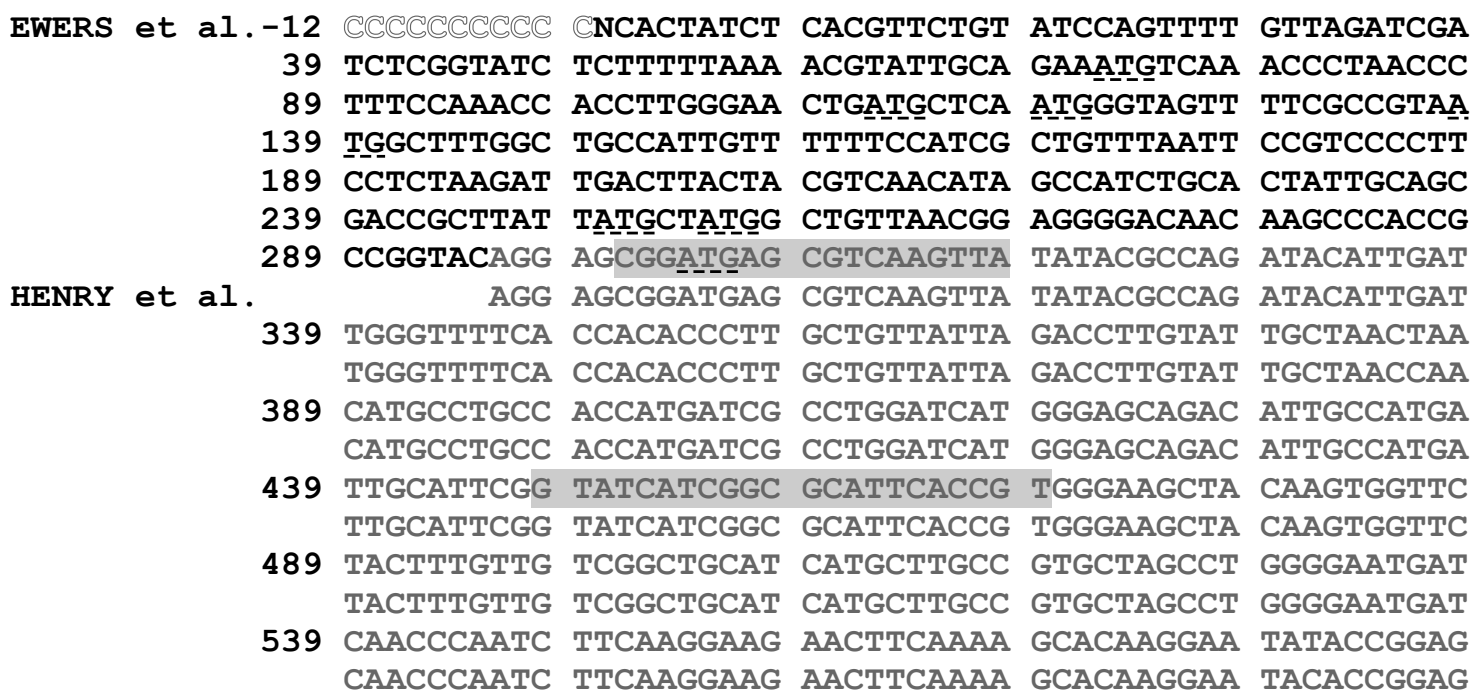




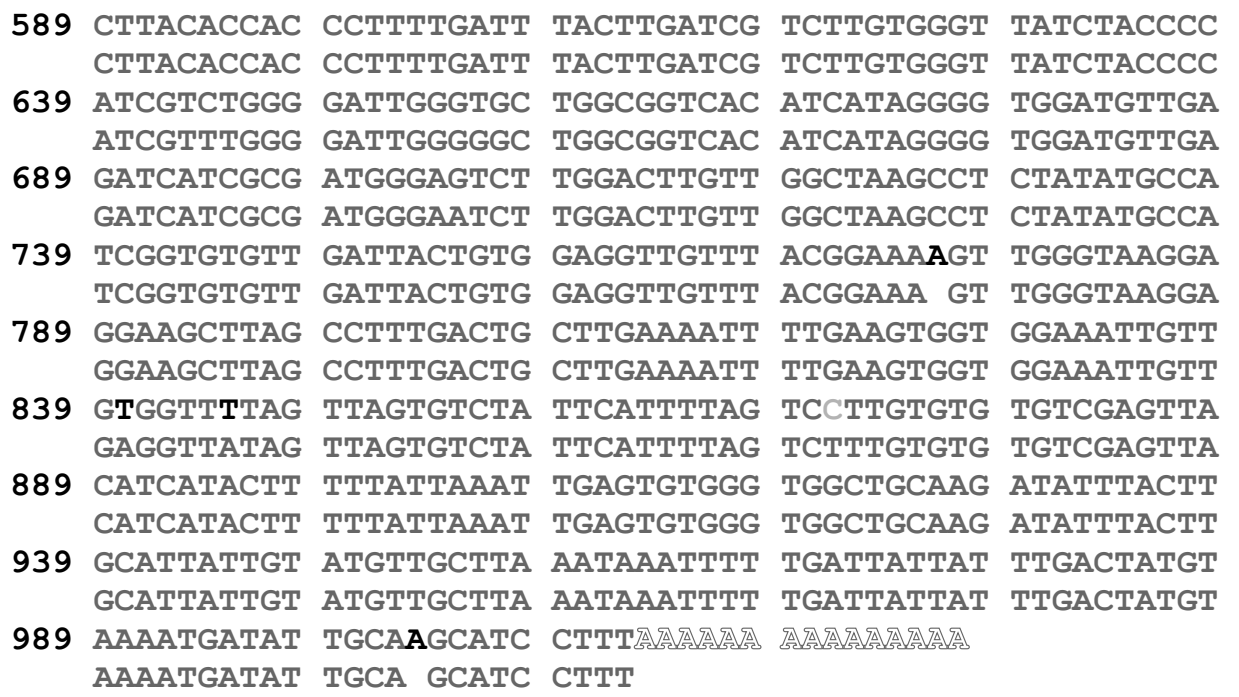

Abbildung 3.4: Komplette, von Überschneidungen bereinigte Nukleinsäuresequenz der in Abb. 3.3 gezeigten PCR-Produkte im Vergleich mit der Ausgangssequenz von HENRY et al. Bis auf eine Base (871, hellgrau, endgültig doch ein Thymidin) stimmt die Sequenz mit der des vollständig vervielfältigten und klonierten Transkripts (s. Abb.3.6) überein.

Nummerierte Zeilen: Mithilfe der auch für die in Abb. 3.3 gezeigten PCR verwendeten primer ermittelte DNA-Sequenz. Im Vergleich mit der von HENRY et al. publizierten Sequenz neue Information ist in schwarz gehalten, alte Information in grau. Die von den äußeren primern herrührenden und damit nicht zur Sequenz gehörige bzw. nicht direkt ermittelte Sequenzabschnitte des Transkripts sind Konntuariert, die Basen an Position der inneren primer sind hellgrau unterlegt. Mögliche Translations-Startcodons am

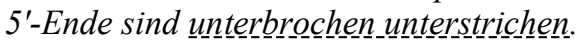

Unnummerierte Zeilen: Von HENRY et al. (2004) publizierte Sequenz (NCBI accession number CF259014)

\subsubsection{Klonierung des vollständigen Transkripts}

Zum einen zur Verifizierung der Sequenz, zum anderen, um das Transkript in manipulierbare, in Bezug auf ihre Vervielfältigung von der PCR unabhängige Form zu bringen, sollte es nun in seiner ganzen Länge vervielfältigt und in einen Vektor kloniert werden. Dazu wurden auf Grundlage der in Abb. 3.4 gezeigten Sequenz neue primer zur Vervielfältigung des gesamten Transkripts entworfen. Sie enthalten Erkennungsstellen für PstI und XbaI zum Zwecke der Klonierung. (Abb. 3.5 a) zeigt das Amplifikat mit der erwarteten Länge von $\approx 1000$ bp.

Die Bande wurde ausgeschnitten, extrahiert und gereinigt, mit PstI und XbaI verdaut und in den ebenfalls mit PstI und XbaI verdauten Vektor pUC19 (s. 2.2.1) ligiert. Nach erfolgter Ligation wurde XL1-blue mit dem Reaktionsansatz transformiert und im blue- 

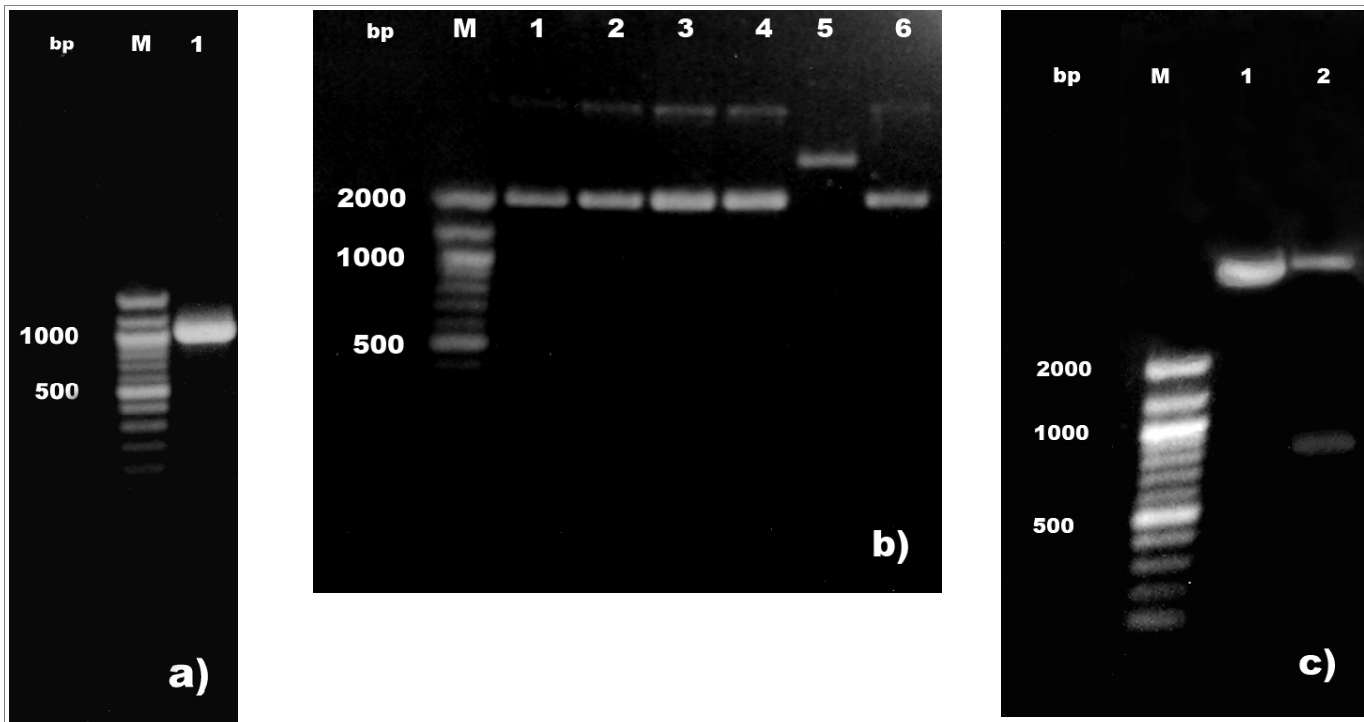

Abbildung 3.5: Generierung der kompletten cDNA von aop und deren Klonierung. $M$ : Längenstandard. a) Darstellung des kompletten Transkripts von aop, amplifiziert mit den primern paopfufw und paopfurev (1). b) Dartstellung der gepickten Klone nach der Transformation des Fragments aus a). 1-6: Klone pUC19-aop-1-6. c) Restriktionsspaltung .von pUC19 (1) und Klon pUC19-aop-5 (2) mit HindIII.

white-screening sechs positive Klone isoliert. Aus den ÜNK wurde Plasmid-DNA isoliert und auf Agarosegelen analysiert (Abb. 3.5 b). Dabei stellten sich fünf Klone als falsch positiv heraus, nur ein Plasmide (pUC19-aop-5,) hatte wie erwartet eine größere Länge als der leere pUC19-Vektor. Eine Verdau von pUC19-aop-5 mit HindIII, das einmal in der MCS von pUC19 und einmal innerhalb von aop schneidet, erbrachte die erwarteten Fragmentlängen von $\approx 800$ bp und des leeren Vektors (Abb. $3.5 \mathrm{c}$ ).

\subsection{Sequenzanalyse von aop}

\subsubsection{Sequenz des vollständigen Transkripts}

Mithilfe von primern, die an vektoreigene Sequenzen binden (M13 forward (-21), M13 rev), wurde das Insert von (pUC19-aop-5) sequenziert. Die Sequenz ist in Abb. 3.6 zu sehen.

1 CACTATCTCA CGTTCTGTAT CCAGTTTTGT TAGATCGATC TCGGTATCTC

51 TTTTTAAAAC GTATTGCAGA AATGTCAAAC CСTAACCCTT TCCAAACCAC $\begin{array}{llllllllll}\mathbf{M} & \mathbf{S} & \mathbf{N} & \mathbf{P} & \mathbf{N} & \mathbf{P} & \mathbf{F} & \mathbf{Q} & \mathbf{T} & \mathbf{T}\end{array}$

101 CTTGGGAACT GATGCTCAAT GGGTAGTTTT CGCCGTAATG GCTTTGGCTG $\begin{array}{lllllllllllllllll}\text { I } & \mathbf{G} & \mathbf{T} & \mathrm{D} & \mathbf{A} & \mathrm{Q} & \mathbf{W} & \mathbf{V} & \mathbf{V} & \mathbf{F} & \mathbf{A} & \mathbf{V} & \mathbf{M} & \mathbf{A} & \mathrm{L} & \mathbf{A} & \mathbf{A}\end{array}$ 
151 CCATTGTTTT TTCCATCGCT GTTTAATTCC GTCCCCTTCC TCTAAGATTG $\begin{array}{llllllllllllllll}I & V & F & S & I & A & V & Q & F & R & P & L & P & L & R & L\end{array}$

201 ACTTACTACG TCAACATAGC CATCTGCACT ATTGCAGCGA CCGCTTATTA $\begin{array}{lllllllllllllllll}\mathbf{T} & \mathbf{Y} & \mathbf{Y} & \mathrm{V} & \mathbf{N} & \mathrm{I} & \mathbf{A} & \mathbf{I} & \mathbf{C} & \mathbf{T} & \mathrm{I} & \mathbf{A} & \mathbf{A} & \mathbf{T} & \mathbf{A} & \mathbf{Y} & \mathbf{Y}\end{array}$

251 TGCTATGGCT GTTAACGGAG GGGACAACAA GCCCACCGCC GGTACAGGAG $\begin{array}{lllllllllllllllll}\mathbf{A} & \mathbf{M} & \mathbf{A} & \mathrm{V} & \mathbf{N} & \mathbf{G} & \mathbf{G} & \mathrm{D} & \mathbf{N} & \mathrm{K} & \mathrm{P} & \mathbf{T} & \mathbf{A} & \mathbf{G} & \mathbf{T} & \mathbf{G} & \mathbf{A}\end{array}$

301 CGGATGAGCG TCAAGTTATA TACGCCAGAT ACATTGATTG GGTTTTCACC $\begin{array}{llllllllllllllll}D & \mathbf{E} & \mathrm{R} & \mathbf{Q} & \mathrm{V} & \mathrm{I} & \mathrm{Y} & \mathbf{A} & \mathrm{R} & \mathrm{Y} & \mathrm{I} & \mathrm{D} & \mathrm{W} & \mathrm{V} & \mathrm{F} & \mathrm{T}\end{array}$

351 ACACCCTTGC TGTTATTAGA CCTTGTATTG CTAACTAACA TGCCTGCCAC $\begin{array}{llllllllllllll}\text { T } & \text { P } & \text { L } & \text { D } & \text { L } & \text { V } & \text { L } & \text { L } & \text { T } & \text { N } & \text { M } & \text { P } & \underline{A} & \mathbf{T}\end{array}$

401 CATGATCGCC TGGATCATGG GAGCAGACAT TGCCATGATT GCATTCGGTA \begin{tabular}{lllllllllllllllll}
$M$ & $I$ & $A$ & $W$ & $I$ & $M$ & $G$ & $A$ & $D$ & $I$ & $A$ & $M$ & $I$ & $A$ & $F$ & $G$ & $I$ \\
\hline
\end{tabular}

451 TCATCGGCGC ATTCACCGTG GGAAGCTACA AGTGGTTCTA CTTTGTTGTC

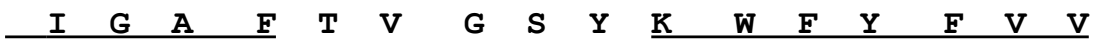

501 GGCTGCATCA TGCTTGCCGT GCTAGCCTGG GGAATGATCA ACCCAATCTT $\begin{array}{llllllllllllllllll}\text { G } & \text { C } & \text { I } & \text { M } & \text { L } & \text { A } & \text { V } & \text { L } & \text { A } & \text { W } & \text { G } & \text { M } & \text { I } & \text { N } & \text { P } & \text { I } & \text { F }\end{array}$

551 CAAGGAAGAA CTTCAAAAGC ACAAGGAATA TACCGGAGCT TACACCACCC $\begin{array}{lllllllllllllllll}K & \mathbf{E} & \mathbf{E} & \mathbf{L} & \mathbf{Q} & \mathrm{K} & \mathrm{H} & \mathrm{K} & \mathbf{E} & \mathbf{Y} & \mathbf{T} & \mathbf{G} & \mathbf{A} & \mathbf{Y} & \mathbf{T} & \mathbf{T} & \mathbf{L}\end{array}$

601 TTTTGATTTA CTTGATCGTC TTGTGGGTTA TCTACCCCAT CGTCTGGGGA $\begin{array}{llllllllllllllll}\text { L } & I & \text { Y } & \text { L } & \text { I } & \text { V } & \text { L } & \text { W } & \text { V } & \text { I } & \text { Y } & \text { P } & \text { I } & \text { V } & \text { W } & \text { G }\end{array}$

651 TTGGGTGCTG GCGGTCACAT CATAGGGGTG GATGTTGAGA TCATCGCGAT

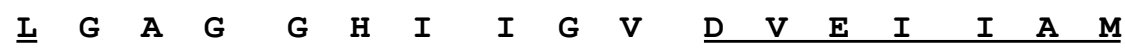

701 GGGAGTCTTG GACTTGTTGG CTAAGCCTCT ATATGCCATC GGTGTGTTGA

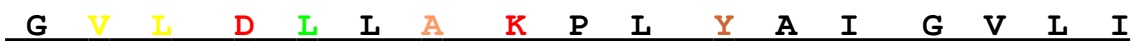

751 TTACTGTGGA GGTTGTTTAC GGAAAAGTTG GGTAAGGAGG AAGCTTAGCC $\begin{array}{llllllllllllllll}T & \text { V } & \text { E } & \text { V } & \text { V } & \text { Y } & \text { G } & \text { K } & \text { V } & G & \text { G } & \text { G } & G & \text { S } & \text { L } & A\end{array}$

801 TTTGACTGCT TGAAAATTTT GAAGTGGTGG AAATTGTTGT GGTTTTAGTT $\begin{array}{lllllllllllllllll}\text { F } & \text { D } & \text { C } & \text { L } & \text { K } & \text { I } & \text { L } & \text { K } & \text { W } & \text { W } & \text { K } & \text { L } & \text { L } & \text { W } & \text { F } & \text { Q } & \text { L }\end{array}$

851 AGTGTCTATT CATTTTAGTC TTTGTGTGTG TCGAGTTACA TCATACTTTT $\begin{array}{lllllllllllllllll}V & S & I & H & F & S & L & C & V & C & R & V & T & S & Y & F & L\end{array}$

901 TATTAAATTG AGTGTGGGTG GCTGCAAGAT ATTTACTTGC ATTATTGTAT L $\mathbf{N}$ *

951 GTTGCTTAAA TAAATTTTTG ATTATTATTT GACTATGTAA AATGATATTG

\section{CAAGCATCCT TTAAAAAAAA AAAAAAA}

Abbildung 3.6: Endgültige cDNA-Sequenz von aop nach der Sequenz von Klon pUC19-aop-5 mit nach dem für Acetabularia gültigen genetischen Code (OSAWA et al., 1992) abgeleiteter Aminosäurensequenz für den ersten $O R F$.

DNA: Als Translations-Startcodon (unter untersuchten angenommen. Die angenommene Polyadenylierungs-Signalsequenz ist invertiert dargestellt. Vom genetischen Standard-Code abweichende Codons (TAA, TAG $\rightarrow$ Gln) sind rot unterlegt (s. 3.4.1).

Aminosäuren: Aminosäuren werden im Ein-Buchstabencode dargestellt.Hypothetische Transmembransegmente (TMS, 3.3.2.2, 3.3.2.3) sind einfach unterstrichen. Mit den PROSITE-consensuspatterns der Typ-1-Rhodopsine (s. Abb. 3..11) übereinstimmende Sequenzen sind farblich gekennzeichnet. 


\section{Translationsinitiation}

Von sechs in Nähe des 5'-Endes liegenden möglichen Initiationssignalen für die Translation der mRNA (AUG, s. Abb. ) kommen nur drei in näheren Betracht, da nur sie am Beginn eines offenen Leserasters (open reading frame; ORF) stehen, während die von den Übrigen geöffneten Leseraster von Terminationssignalen (UGA) auf eine für ein funktionelles Protein zu kurze Länge begrenzt werden (maximale Länge: 61 Aminosäuren).

Die danach möglichen Startcodons sind in Tabelle 2 in Bezug auf ihre Umgebung im Vergleich mit Literaturdaten über den Kontext des Translations-Initiationssignals in mRNAs dargestellt. KOZAK (1986) ermittelte zuerst eine modulierende Wirkung der dem Startcodon vorgelagerten Basen auf die Translation der betroffenen mRNA. Aufgrund weiterer funktioneller und statistischer Untersuchungen über die Verteilung der Basen in der Umgebung funktioneller Startcodons (KOZAK, 1987) wurde eine Consensus-Sequenz für den Kontext gefunden, welche Abweichungen zwischen den einzelnen Phyla aufweist und deren Wirkung auf das Translationsniveau und damit auf die Expressionsstärke bis jetzt nicht geklärt ist. Als Hilfsmittel zur Identifikation funktioneller Startcodons scheinen solche Consensus-Sequenzen insbesondere vor dem Hintergrund verbesserter Datenlage für Pflanzen (JOSHI et al., 1997) jedoch geeignet. Speziell für Acetabularia gibt es noch keine Untersuchungen hinsichtlich des Kontextes des Translations-Initiationssignalen. 
Tabelle 2: Relative Häufigkeiten der Basen und Consensus-Sequenz in Umgebung des Translationsinitiationssignals AUG in mRNAs verschiedener Phyla (JOSHI et al., 1997). Darunter die tatsächliche Umgebung der drei für Acetabularia-Opsin in Betracht kommenden TranslationsiStartcodons. Darin sind mit einem Literatur-Consensus übereinstimmenden Basen fett gedruckt, solche mit zwei Übereinstimmungen doppelt unterstrichen. Basen ohne Übereinstimmung sind in

Kleinbuchstaben dagestellt, wenn keiner der Literaturwerte eine relative Häufigkeit von $15 \%$ übersteigt.

\begin{tabular}{|c|c|c|c|c|c|c|c|c|c|c|}
\hline Relative Position & -6 & -5 & -4 & -3 & -2 & -1 & $\boldsymbol{A U G}$ & +4 & +5 & +6 \\
\hline \multicolumn{11}{|l|}{ Pflanzen } \\
\hline $\mathrm{A} \%$ & 33 & 28 & 44 & 55 & 42 & 42 & & 15 & 21 & 19 \\
\hline $\mathrm{C} \%$ & 16 & 30 & 22 & 8 & 34 & 27 & & 6 & 54 & 14 \\
\hline $\mathrm{G} \%$ & 25 & 17 & 18 & 26 & 9 & 20 & & 68 & 15 & 35 \\
\hline U\% & 25 & 25 & 15 & 10 & 15 & 11 & & 12 & 10 & 33 \\
\hline Consensus & $\mathbf{a}$ & c & $\mathbf{a}$ & $\mathbf{A}$ & $\mathrm{A} / \mathrm{C}$ & $\mathbf{a}$ & & $G$ & $\mathbf{C}$ & g \\
\hline \multicolumn{11}{|l|}{ Niedere Pflanzen } \\
\hline $\mathrm{A} \%$ & 23 & 15 & 44 & 73 & 48 & 40 & & 14 & 12 & 15 \\
\hline $\mathrm{C} \%$ & 16 & 39 & 35 & 8 & 31 & 34 & & 20 & 57 & 29 \\
\hline $\mathrm{G} \%$ & 41 & 22 & 12 & 18 & 14 & 20 & & 55 & 18 & 29 \\
\hline $\mathrm{U} \%$ & 20 & 23 & 9 & 2 & 7 & 6 & & 10 & 12 & 27 \\
\hline Consensus & g & c & $\mathrm{A} / \mathrm{C}$ & $\mathbf{A}$ & $\mathrm{A} / \mathrm{C}$ & $\mathbf{a}$ & & $G$ & $\mathrm{C}$ & c/g \\
\hline \multicolumn{11}{|l|}{ aop } \\
\hline 1. Startcodon & g & $\underline{\mathbf{c}}$ & $\underline{\mathbf{A}}$ & $\mathrm{G}$ & $\underline{\mathbf{A}}$ & $\underline{\mathbf{a}}$ & & $\mathrm{t}$ & $\underline{\mathbf{C}}$ & A \\
\hline 4. Startcodon & $\mathbf{g}$ & $\underline{\mathbf{c}}$ & C & $\mathrm{G}$ & $\mathrm{t}$ & $\underline{\underline{\mathbf{a}}}$ & & $\underline{\mathbf{G}}$ & $\underline{\mathrm{C}}$ & $\mathrm{T}$ \\
\hline 6. Startcodon & $\mathrm{T}$ & A & $\mathrm{t}$ & $\mathrm{G}$ & $\underline{\mathrm{C}}$ & $\mathrm{t}$ & & $\underline{\mathbf{G}}$ & $\underline{\mathrm{C}}$ & $\mathrm{T}$ \\
\hline
\end{tabular}

Der Kontext des ersten und vierten Startcodons zeigt einen sehr ähnlichen Grad der Übereinstimmung mit der Consensus-Sequenz für niedere Pflanzen, während das sechste Startcodon in einen stark abweichenden Kontext eingebettet ist und damit als untypisch für Pflanzen und niedere Pflanzen im Besonderen anzusprechen ist. Bei Betrachtung der Lage der erwarteten TMHs in der abgeleiteten Aminosäuren-Sequenz von AOP (Abb. 3.10) erscheint die Funktion des vierten Startcodons als TranslationsInitiationssignal ebenfalls unwahrscheinlich, da das entsprechende Methionin inmitten eines solchen TMS läge. Deshalb wurde das erste AUG als TranslationsInitiationssignal angenommen. 


\section{Weitere cis-Elemente}

Als regulatives Element der mRNA-Prozessierung findet sich in der 3'-untranslatierten Region (3'-untranslated region, 3'-UTR) nach dem Translations-Terminationssignal (UGA) die für Eukaryoten beschriebene Consensus-Sequenz AAUAAA (PROUDFOOT \& BROWNLEE, 1976), welche, für Pflanzen als near upstream element (NUE) bezeichnet, ein Bestandteil des Polyadenylierungssignals ist. Das NUE positioniert die Abspaltung des äußersten 3'-Endes der prä-mRNA und damit auch die Polyadenylierung, die dauraufhin an der Spaltungsstelle katalysiert wird, welche deshalb auch polyA-site genannt wird (Übersichtsartikel: ZHAO et al. (1999), für Pflanzen:ROTHNIE (1996)). Auch in Genen von A. acetabulum sind solche NUEs bekannt (SERIKAWA \& MANDOLI, 1999).

\subsubsection{Analyse der abgeleiteten Aminosäurensequenz von AOP}

\subsubsection{Dotplots}

Ein erster Eindruck von der Ähnlichkeit von Sequenzen läßt sich mithilfe von dotplots (GIBBS \& MCINTYRE, 1970) gewinnen. Ein dotplot entsteht, wenn die Eemente einer Sequenz in die Reihen und die Elemente einer zu vergleichenden Sequenz in die Spalten einer Matrix eingetragen werden. Nach Kennzeichnung der Übereinstimmungen durch Punkte werden für ähnliche Sequenzen diagonal verlaufende Linien sichtbar, unähnliche Sequenzen erzeugen lediglich durch zufällig verteilte Ähnlichkeit verursachte Streuung.

Abb. 3.7 a) zeigt BOP als Prototypen eines Typ-1-Opsins im Vergleich mit AOP. Wie für Opsine als vergleichsweise diverse Proteinfamilie (vgl. NAGEL et al., 2005) zu erwarten, zeigen sich nur wenige kurze Regionen mit Übereinstimmungen, welche miteinander verbunden jedoch in etwa die Diagonale der Matrix bilden, was die Ähnlichkeit von sich jeweils in ihrer Position in der Primärstruktur entsprechenden Regionen (Motiven) nahelegt. Der zum Vergleich für zwei typische Mitglieder dieser Familie herangezogene dotplot Bacterioopsin versus Haloopsin zeigt ein sehr ähnliches Bild, während der dotplot Bacterioopsin versus Rinder-Opsin das Fehlen von Übereinstimmungen illustriert. Das war ebenfalls zu erwarten, denn bei Rinder-Opsin handelt es sich um ein Opsin vom Typ 2, deren Homologie mit den Typ-1-Opsinen, wenn auch möglicherweise vorhanden, so doch bis heute unkenntlich ist 


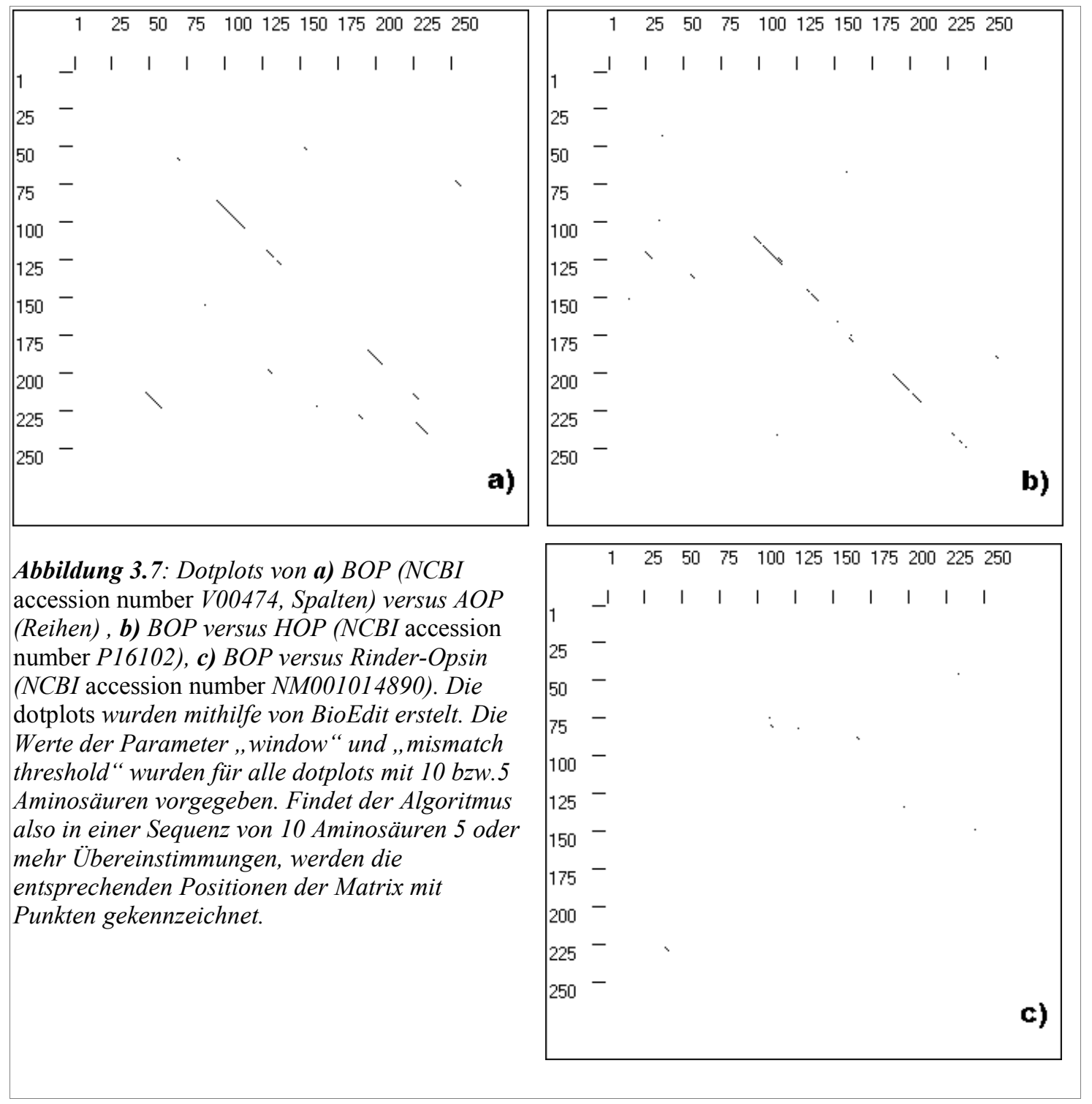

(HENDERSON \& SCHERTLER, 1990) oder nur über den Weg einer Brücke über Opsine (COP1 aus Chlamydomonas reinhardtii) dargestellt werden kann (DEININGER et al., 2000). Ein dotplot Bacterioopsin versus Zufallssequenz zeigt ein vergleichbares Muster; es wird hier nicht gezeigt, um Redundanz zu vermeiden.

Neben den in den Bereich der Diagonale fallenden Übereinstimmungen sind in Abb 3.7 a) weitere in der Peripherie der Matrix gelegene Übereinstimmungen zu erkennnen. Diese Beobachtung ist auch für homologe Proteine zunächst überraschend, denn sie bedeutet, daß Bereiche Ähnlichkeiten aufweisen, die sich nicht im gleichen Kontext befinden, für den Fall im linken unteren Bereich von des dotblots liegen sie 200 Aminosäuren voneinander entfernt (Abb. 3.8).

Als Grund könnte gemutmaßt werden, daß beide Bereiche ähnliche strukturelle Umgebungen haben. Sie kommen ihren intramolekularen Gegenstücken im nativen 
AOP EIIAMGVLDLLAKPLYAIGVII 227 BOP LVKGMGVSDPDAKKFYAITTLV 36

Abbildung 3.8: Alignment zweier ähnlicher Bereiche von Acetabularia-Opsin (AOP) und Bacterioopsin (BOP), welche in der Primärstruktur sehr weit auseinanderliegen, detektiert durch dotblot a) in Abb. 3.7. Identische Aminosäuren sind dunkelgrau hinterlegt, Konservative Substitutionen (welche jedoch für den abgebildeten dotplot keine Rolle spielten), hellgrau.
Protein räumlich recht nahe und haben beide Kontakt mit dem Cofaktor Retinal (s. Abb. 3.9). In einem solchen Fall wäre in evolutionärer Hinsicht von einer Analogie auszugehen, die Ähnlichkeit wäre also nicht auf Verwandschaft zurückzuführen, sondern auf Anpassung an ähnliche Funktion und Umgebung. Genetische Umordnungen durch mobile genetische Elemente (MGE, s.

KAZAZIAN, 2004) können ebenfalls für ähnliche Bereiche außerhalb des sequenziellen Kontextes sorgen (vgl. BENNETZEN, 2000). In diesem Fall könnte von einer evolutionären Homologie gesprochen werden.

\subsubsection{Voraussage der Topologie}

Handelt es sich bei AOP um ein Opsin vom Typ 1, sollte es in nativer Umgebung sieben TMHs ausbilden. Abb. 3.9 zeigt das Ergebnis der Voraussage durch das DAS-TMfilter prediction tool. Der DAS-Algorithmus ist nicht geeignet, die Grenzen einer TMH vorauszusagen, reliabel sind lediglich Position des Zentrums einer TMH und die Zugehörigkeit der umgebenden Aminosäuren. Deshalb werden die positiv vorausgesagten Bereiche auch als TM-core bezeichnet.

BOP bildet wie erwartet (s. GRIGORIEFF et al., 1996) laut Voraussage sieben TMHs aus, während für AOP acht TMHs vorausgesagt werden. Wird die leader-Sequenz (DUNN et al., 1981) von BOP außer Betracht genommen, stimmen die ersten 7 vorausgesagten Helices in ihrer Lage mit denen von BOP überein, nur Helix II ist bei AOP gegenüber BOP leicht in Richtung des N-Terminus verschoben. Die im Falle von AOP unsichere Helix IV erscheint im Vergleich mit der Kurve von BOP ebenfalls als gesichert, ähneln sich die Kurvenverläufe gerade in dieser Region doch sehr. Helix VI zeigt bei AOP einen besonders hohen Gipfel, während der Gipfel für BOP nur auf Niveau der Übrigen ist. Die für AOP vorausgesagte Helix VIII hat von allen vorasgesagten Helices das schlechteste Evalutionsergebnis, also die höchste Wahrscheinlichkeit, eine falsch Positive zu sein.

Bis auf die letzte Helix zeigt AOP eine BOP ähnliche Topologie. AOP ist laut 


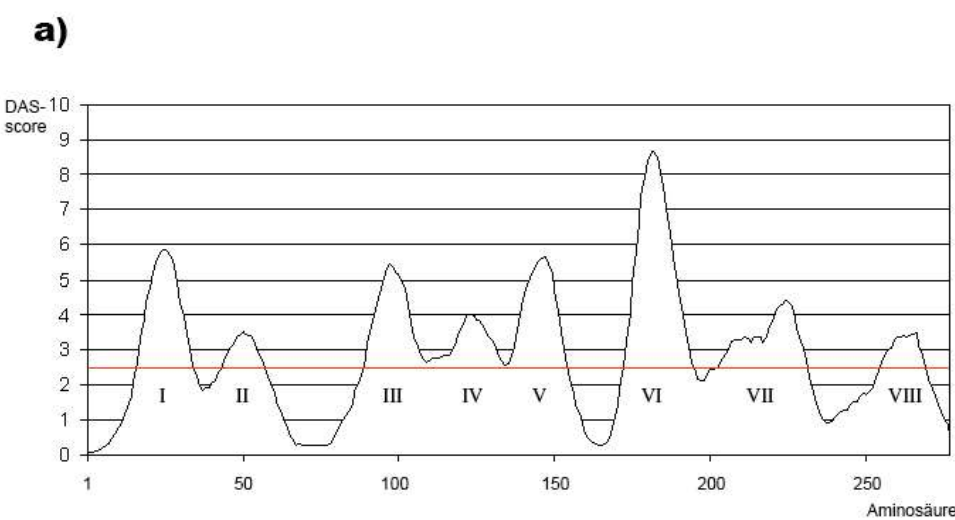

b)

Abbildung 3.9: DAS-Kurve von a) $A O P$ und b) BOP. Ausreichend lange Bereiche oberhalb des empirischen Schwellenwertes (rote Gerade) wertet der Algorithmus als zu einer TMH gehörig. Für AOP werden 8 TMHs (I-VIII) vorausgesagt, welche von DASTMfilter alle als richtig Positive gewertet werden. Für AOP sagt der Algorithmus 7 TMHs (I-VII)

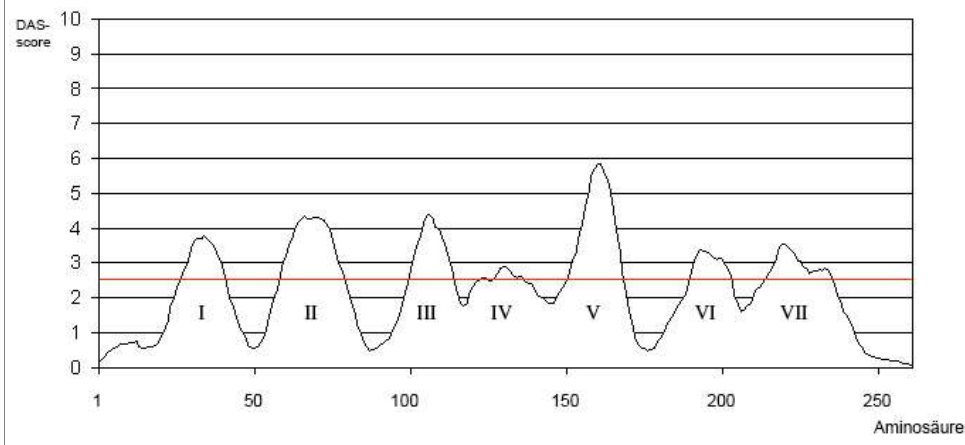
voraus, davon werden alle 7 als richtig Positive evaluiert. Im Falle von AOP kann der Algorithmus Helix IV nicht von den umgebenden Helices abgrenzen und weist darauf hin, daß es sich gegebenenfalls um drei Helices mit zwei kurzen linkers handelt.

Voraussage nach dem $D A S$-Algorithmus ein TMP, das außer der für Opsine erwarteten 7 TMHs noch eine weitere C-terminale TMH aufweist.

\subsubsection{Multiple Sequence Alignment}

Für den ersten Blick auf die Ähnlichkeit von Acetabularia-Opsin mit anderen Opsinen sind dotplots sehr nützlich, und die Erkenntnis, daß AOP und BOP eine ähnliche Toplologie aufweisen, unterstützen die Einordung von AOP als Typ-1-Opsin. Noch tiefere Einsicht können multiple sequence alignments gewähren (Übersicht: WALLACE et al., 2005). Abb. 3.10 zeigt ein solches alignment von AOP mit weiteren Mitgliedern der Opsine vom Typ 1. Es enthält zwei Protonenpumpen, mit BOP als Prototyp dieser Proteinfamilie eine aus dem Reich der Prokaryoten, und mit LOP eine aus dem der Eukaroten. HOP ist eine Chloridpumpe. Zwei sog. sensorische Opsine, die an der Phototaxis von Archaeen beteiligt sind, sind in Gestalt von SOPI und SOPII enthalten. CHOP1 spielt als Licht-aktivierter Protonenkanal ebenfalls eine sensorische Rolle bei der Phototaxis eines Eukaryoten. 


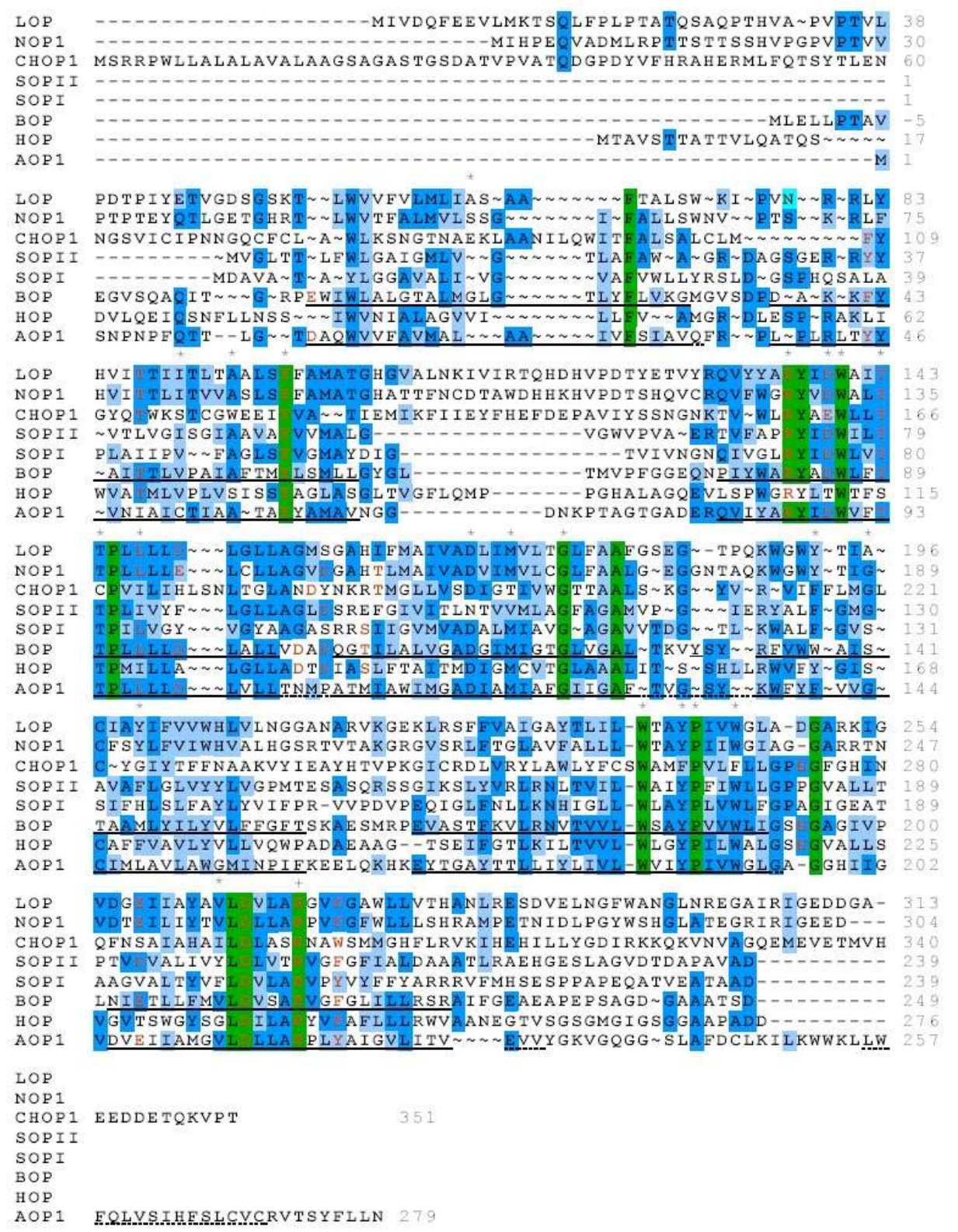

Abbildung 3.10: Multiple alignment von AOP mit einer Auswahl weiterer Opsine vom Typ 1. NOP1: Neurospora-Opsin 1 (NCBI accession number AF135863), CHOPI ChlamydomonasChannelopsin 1 (NCBI accession number: AF385748); SOPII: Natronomonas Sensory Opsin II (NCBI accession number: P42196); SOPI: Halobacterium Sensory Opsin I (NCBI accession number: P25964). $Z u$ beachten ist, daß die Zählung der Aminosäuren von BOP nach der Leader-Sequence beginnt. Das alignment wurde mithilfe des Computerprogramms ClustalW erstellt und anschließend manuell editiert. Als Substitutionsmatrix wurde BLOSUM62 (HENIKOFF \& HENIKOFF, 1992) verwendet. Gaps sind als - (vom Algorithmus errechnet) oder (von Hand hinzugefügt) dargestellt. Der Farbcode ist im Wesentlichen von NAGEL et al., 2001 übernommen. Identische Aminosäuren sind dunkelblau hinterlegt, Konservative Substitutionen helblau. Als solche wurde dabei ein Wert von mindestens 1 Bit nach der verwendenten Matrix gewertet. Für alle Opsine identische Aminosäuren sind grün hinterlegt. An der Protonen-Translokation durch BR beteiligte Aminosäuren (LANYI, 2001) sind rot eingefärbt. Aminosäuren, die in BR erwiesenermaßen mit dem Cofaktor Retinal interagieren, sind mit einem * gekennzeichnet, die Retinal-Bindungsstelle selbst mit + . TMHs in BR (GRIGORIEFF et al., 1996) und entsprechende Bereiche in AOP sind durch fette Unterstreichungen gekennzeichnet. Diese Bereiche stimmen mit den durch von Sequenz-Homologie unabhängigen Strukturvoraussagen (3.3.2.2) in ihrer Position überein. Gehen die in 3.3.2.2 ermittelten TM-cores in ihrer Ausdehnung über die anhand von Sequenz-Homologie bestimmten TMH hinaus, sind sie unterhrochen unterstrichen. 
Die Primärstruktur von AOP hat fast auf ihrer gesamten Länge, außer den unmittelbaren N- und C-Termini, Ähnlichkeit zu den anderen Opsinen. Die Aminosäurensequenzen zeigen gobal, wie die Opsine des Typs 1 generell, einen niedrigen Grad der Konservierung (BOP vs. AOP: 21\% Identität; 38\% Ähnlichkeit). Lokal hingegen finden sich stark konservierte Bereiche (s. a. Abb. 3.11). AOP besitzt Entsprechungen von beiden für Typ-1-Opsine gefundenen consensus patterns in der PROSITE-Datenbank (BUCHER \& BAIROCH, 1994).

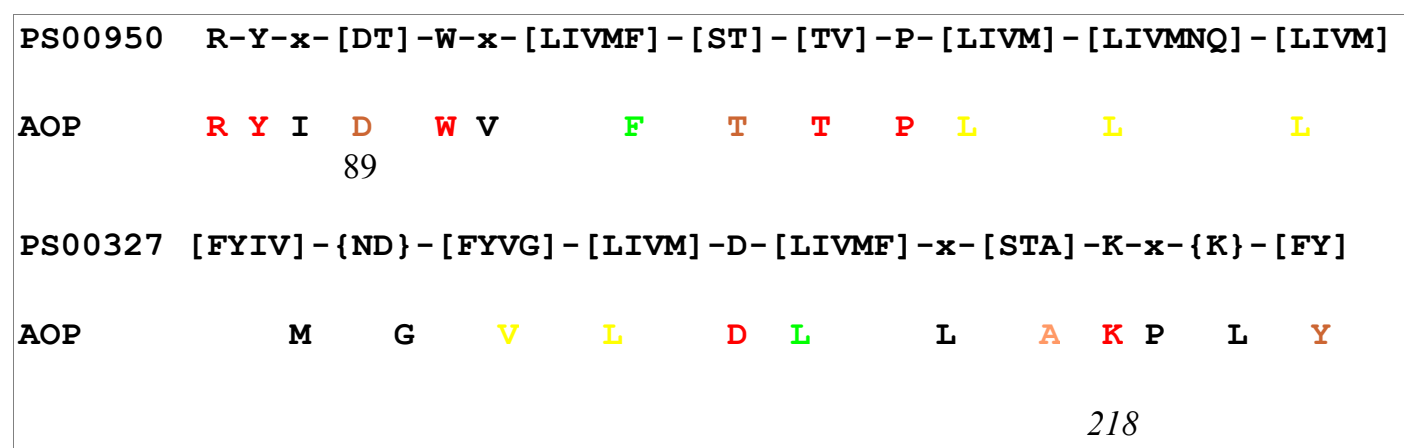

Abbildung 3.11: Consensus patterns PS00950 und PS00327 aus der PROSITE-Datenbank mit entsprechenden Sequenzen von AOP. Der hier verwendete Farbcode für den Grad der Konservierung ist bei Visualisierungen von PROSITE consensus patterns durch die PDBsum-Datenbank üblich. Je roter, desto stärker konseviert ist die jeweilige Aminosäure.

Die Abb.en 3.10 und 3. 11 zeigen, dass Lys ${ }^{218}$ die Retinal-Bindungsstelle in AR ist.

Die Aminosäure $\mathrm{Asp}^{85}(\mathrm{BR})$ sorgt in archeellen Rhodopsinen für die Ionenselektivität und ist ausschließlich in Protonen translozierenden Rhodopsinen konserviert (CHOP1 und CHOP2 tragen an dieser Position Glu). Wird sie in BR durch site directed mutagenesis zu Thr (wie in HR) mutiert, fungiert BR als Chloridpumpe (SASAKI et al, 1995). In AOP ist die entsprechende Aminosäure Asp ${ }^{89}$. AR sollte demnach ein Protonen translozierendes Rhodopsin sein.

$\mathrm{Asp}^{96}$ fungiert in BR als Protonen-Donor bei der Reprotonierung der Schiff'schen Base zwischen Lys ${ }^{216}$ und Retinal während des Überganges $M_{410}^{C P} \Leftrightarrow N_{560}$ des photocycles. Sie ist den bisher identifizierten Protonenpumpen gemeinsam ( $\mathrm{Asp}^{150}$ in LR) und fehlt in anderen Opsinen. Die Konservierung dieser Aminosäure in AOP (Asp $\left.{ }^{100}\right)$ läßt die Vermutung zu, es handele sich bei AR ebenfalls um eine Protonenpumpe. 


\subsubsection{Phylogenie}

Nachdem Typ-1-Rhodopsine in unserer Erkenntnis lange Zeit auf das Reich der Archeaen beschränkt waren, wurde das Spektrum der bekannten Rhodopsine vom Typ1 in jüngerer Zeit beträchtlich erweitert (BIEZKE et al. (1999), BEJA et al. (2000), SINESHCHEKOV et al. (2002), NAGEL et al. (2002)). Abb. 3.12 zeigt einen phylogenetischen Baum der Typ-1-Opsine, ermittelt in Übereinstimmung mehrerer Methoden (s. Abbildungstext).

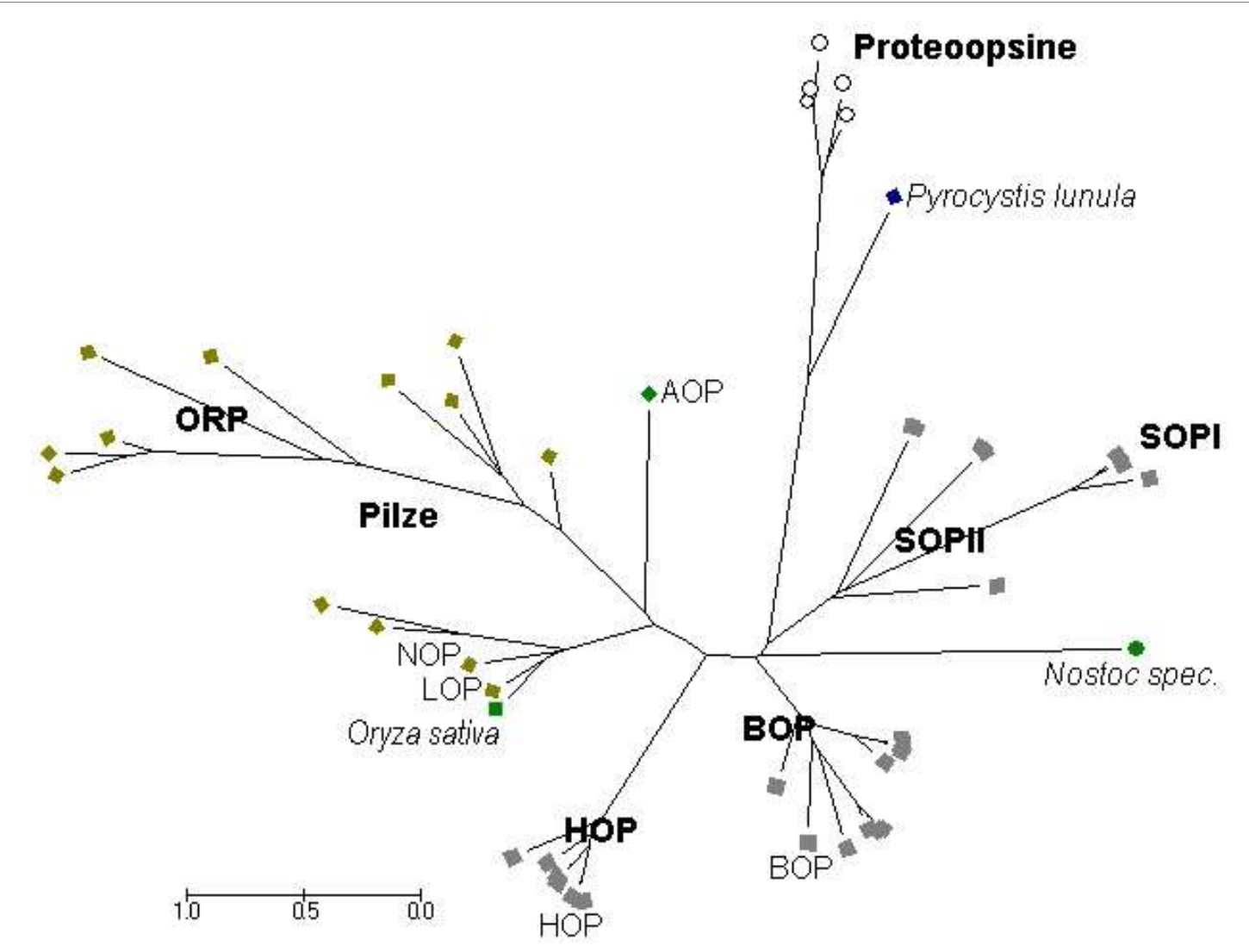

Abbildung 3.12: Phylogenetischer Baum der Typ-1-Opsine nach übereinstimmenden Analysen mithilfe der Methoden des Neighbor Joining (NJ, SAITOU \& NEI (1987)) und der Minimal Evolution (ME).. Opsine archebakterieller ( $\square$ ), eubakterieller (०) und eukaryotischer $(\diamond)$ Herkunft sind gekennzeichnet. Pflanzen sind grün, Pilze gelb und andere Eukaryoten blau gekennzeichnet. Funtionelle/Strukturelle Gruppen sind fettgedruckt: Das als Grundlage dienende multiple sequence alignment wurde mit ClustalW erstellt (Daten nicht gezeigt). Als Substitutionsmatrix diente BLOSUM62.

Der Stammbaum rekonstruiert den von RUIZ-GONZALEZ \& MARIN (2004) ermittelten Stammbaum der Typ-1-Opsine recht gut. AOP steht zwischen den Opsinen der Pilze und den ebenfalls in Pilzen gefundenen opsin related proteins (ORP, BROWN, 2004). 


\subsection{Heterologe Expression von AOP in Oozyten von $X$. laevis}

\subsubsection{Anpassung des genetischen Codes}

Um Acetabularia-Opsin auf eine mögliche Funktion als lichtgetriebene Protonenpumpe $\mathrm{zu}$ untersuchen, sollte es in Oozyten von $X$. laevis exprimiert und voltage-clampExperimenten unterzogen werden. Mit dem originären Gen von Acetabularia ergeben sich aufgrund des abweichenden genetischen Codes von Acetabularia (SCHNEIDER et al., 1989) Probleme. Würde es heterolog in einem Organismus (X. laevis) exprimiert, der den genetischen Standard-Code verwendet, würde die entsprechende mRNA nur bis zum ersten Translations-Stopcodon des Standard-Codes translatiert. Resultat wäre ein nur 34 Aminosäuren langes Polypeptid. Ein weiteres Problem, das Unterschiede in der codon-usage mit sich bringen, ist eine mögliche Unterbrechung der Translation durch mangelnde Verfügbarkeit der vom Zielorganismus selten verwendeter transfer-RNAs (tRNAs, GUSTAFSSON et al., 2004). In Abb. 3.13 ist die DNA-Sequenz von aop mit der Übersetzung nach dem genetischen Code von $X$. laevis und gegen dessen codonusage aufgetragen.

Das erste Translations-Stopcodon nach Standard-Code liegt zwischen Helix I und II (s. Abb. 3.10). Ein bis zu dieser Stelle verkürztes Opsin wäre sicher funktionslos. Um aop funktional in Oozyten von $X$. laevis zu exprimieren, mußte also mindestens das erste Tranlations-Stopcodon ersetzt werden. 


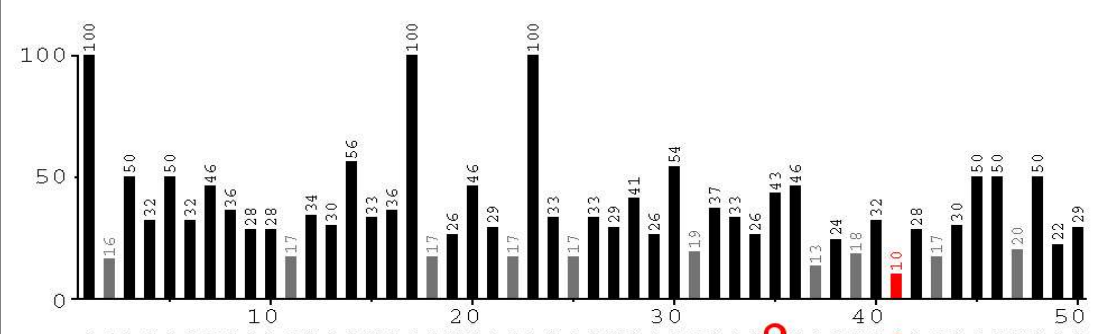

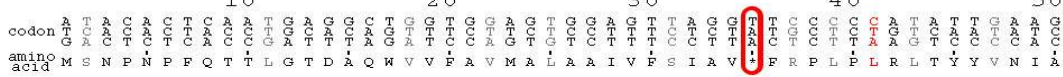

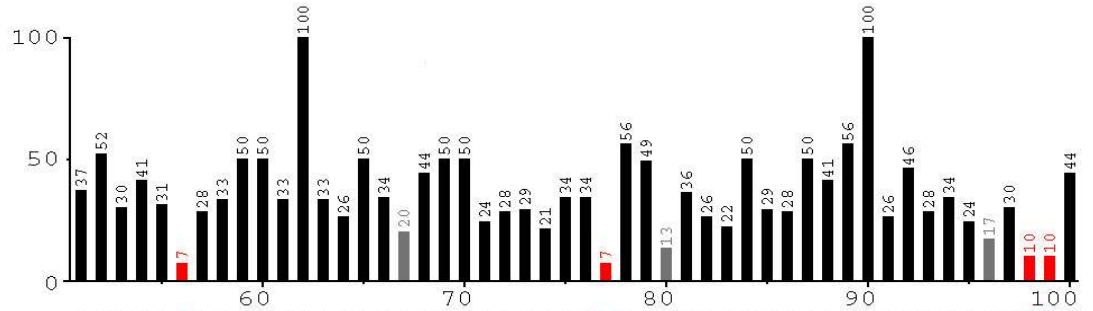

Abbildung 3.13:

Auswurf des Codon-

Usage Analyzers mit

der DNA-Sequenz von

aop (von dem

vermuteten Start-codon

an) und der codon-

usage von X. laevis als

Eingabe. Selten

verwendete codons $(\leq$ 20\%) sind gran

eingefärbt, sehr selten verwendete codons

$(\leq 10 \%)$ rot.

Translations-

Stopcodons, die in Acetabularia für eine Aminosäure codieren,

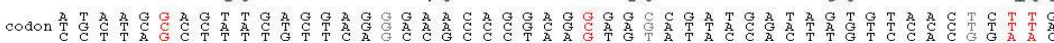
sind rot eingekreist.

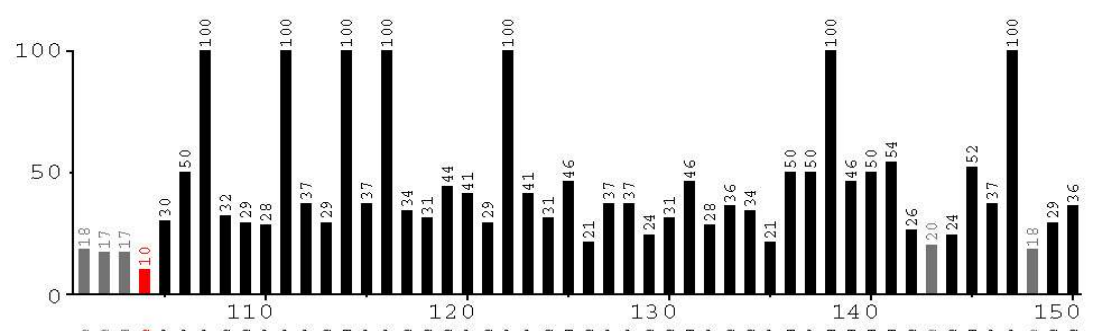

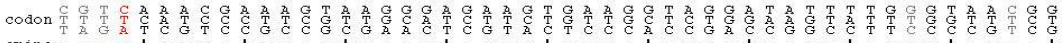

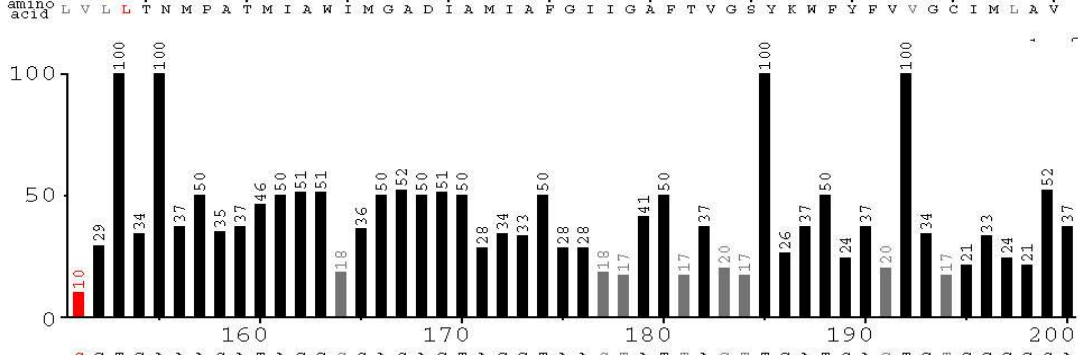

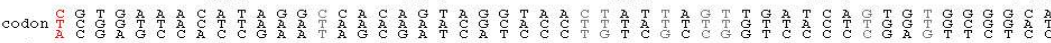

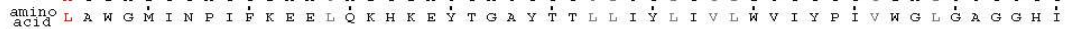

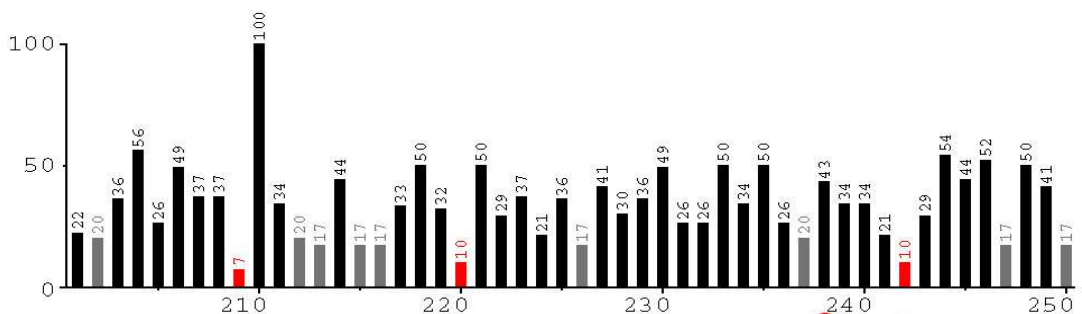

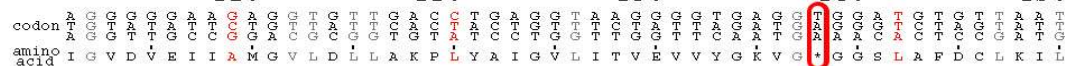

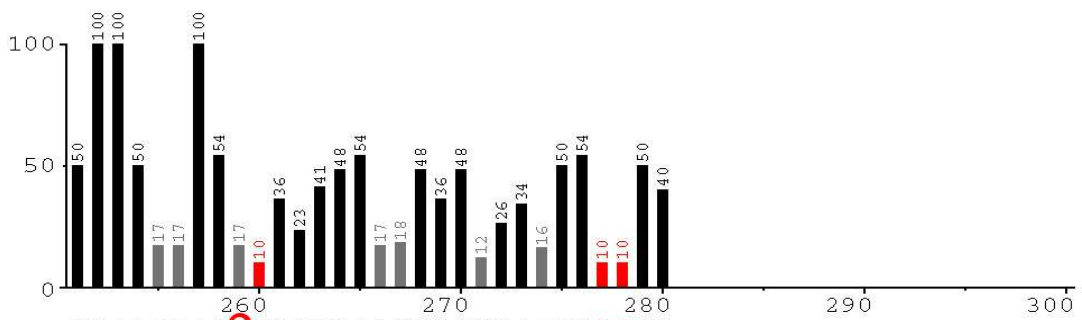

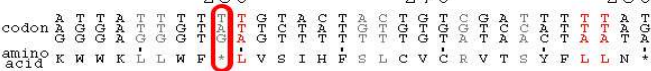




\subsubsection{Mutagenese}

Für die Mutagenese von aop zum Zwecke der heterologen Expression über das erste Stopcodon hinaus reicht die einfache Methode der MegaprimerPCR (s. 2.14.3) aus. Erster und zweiter flankierender primer enthielten Erkennungsstellen für zur Klonierung in den Expressionsvektor passende Restriktionsenzyme (BamHI und XhoI). Der mutagene primer enthielt eine Korrektur von TAA (im genetischen Standard-Code „Stop“) nach CAG (im genetischen Standard-Code „Gln“). Die megaprimer-

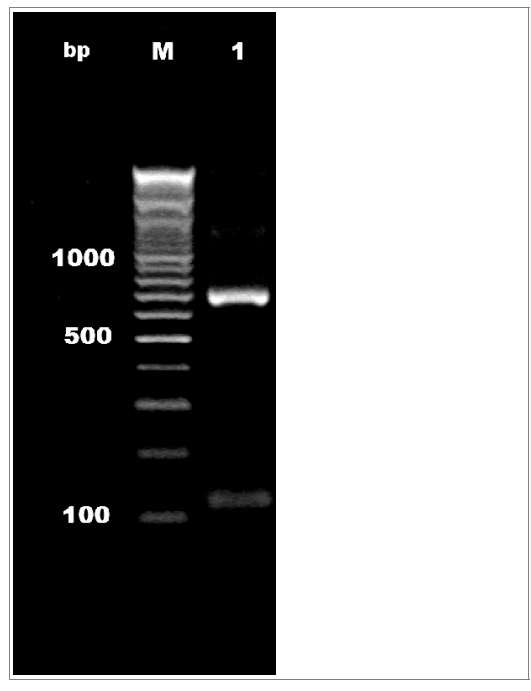
PCR resultierte in einem zu ewartenden Amplifikat von $\approx 700$ bp. Auf dem Agarosegel (Abb. 3.14) ist außerdem der megaprimer mit etwa 120 bp zu sehen.

\subsubsection{Klonierung in den Expressionsvektor pSGEM}

Die in Abb. 3.14 bei $\approx 700$ bp gelegene Bande wurde ausgeschnitten, extrahiert und gereinigt, mit BamHI und XhoI geschnitten und in den ebenfalls mit BamHI und XhoI geschnittenen Vektor pSGEM (s. 2.2.1) ligiert. Fünf im blue-whitescreening positive Klone wurden isoliert. Wie in Abb. $3.15 \mathrm{zu}$ sehen, enthielten von diesen vier Klonen nur zwei ein Plasmid, und nur einer eines mit größerer Länge als der leere Vektor. Eine Sequenzierung ergab die Richtigkeit dieses Klons (pSGEMaopmut2).

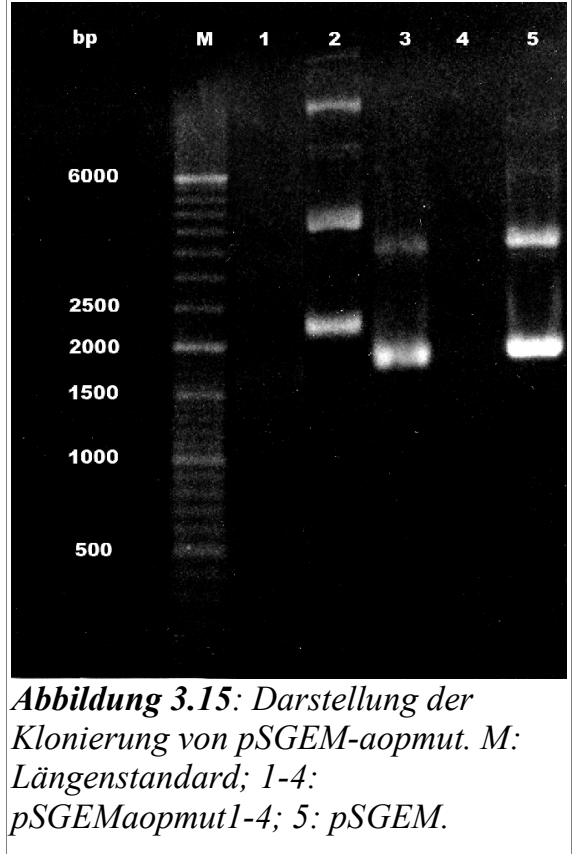




\subsubsection{Elektrische Eigenschaften von in Xenopus-Oozyten}

\section{exprimiertem AR}

Abb. 3.16 zeigt die mit der voltage-clamp-Methode ermittelten grundlegenden elektrischen Phänomene nach heterologer Expression von aop in Oozyten von $X$. laevis. Auf die Beleuchtung mit Grünlicht hin wird über die Plasmamembran von Oozyten, denen pSGEMaopmut injiziert wurde, ein elektrischer Auswärtsstrom gemessen, der nach Ausschalten des Lichts wieder abfällt. Bei Oozyten, denen nur $\mathrm{H}_{2} \mathrm{O}$ injiziert wurde, ist keine Stromantwort zu erkennnen. Rotlicht löst diese Antwort bei AR-exprimierenden Oozyten nicht aus. Die Expression von AR war erfolgreich und AR vermittelt einen Grünlicht-induzierten

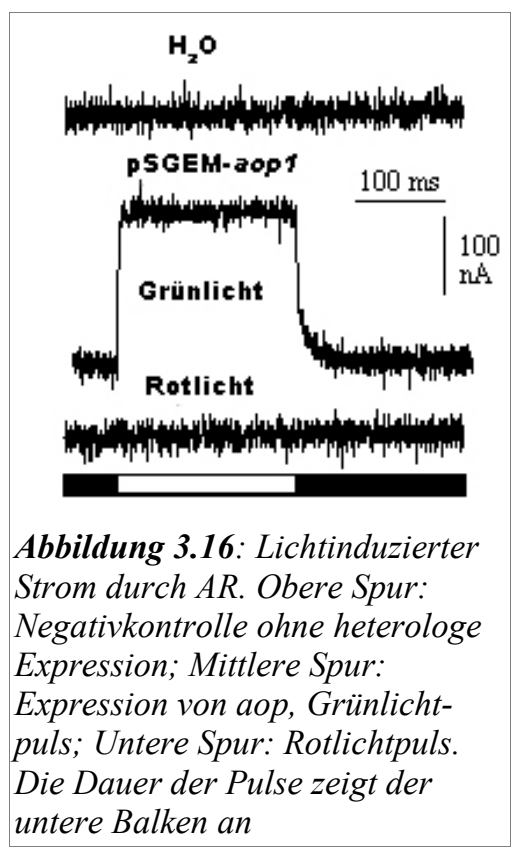

Ladungstransport.

\subsubsection{Einfluss von Membranspannung und $\mathrm{pH}$ auf die lichtinduzierten}

\section{Ströme durch AR}

Der stationäre lichtinduzierte Strom ist sichtlich spannungsabhängig mit einer sigmoiden $\quad \mathrm{I}(\mathrm{V})$-Kurve

(Abb.

3.17), die im Sättigungsbereich bei hohen Spannungen stark positive Ströme, bei negativen Spannungen schwach positive Ströme wiedergibt. Sowohl $\mathrm{pH}_{\mathrm{i}}$ als auch $\mathrm{pH}_{\mathrm{o}}$ haben einen deutlichen Effekt auf den Strom, was auf Protonen als Träger der transportierten Ladung deutet. Das positive a)

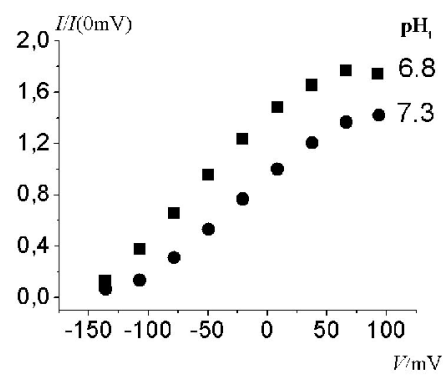

b)

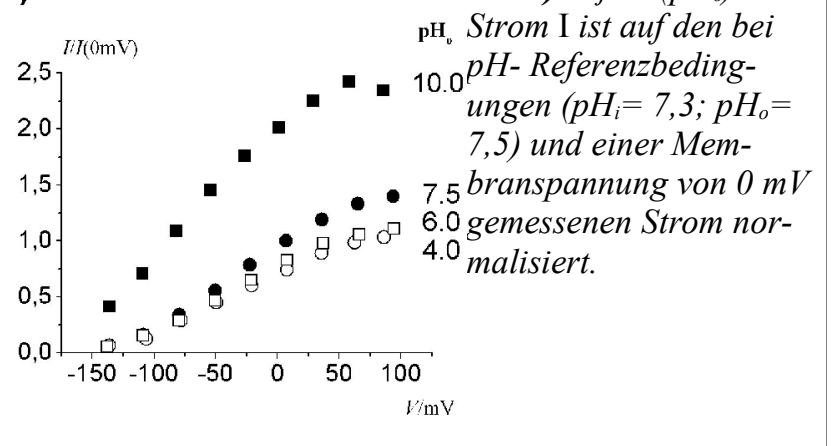

Abbildung 3.17:

Stationäre

lichtinduzierte Ströme durch AR als Funktion der Haltespannung bei verschiedenen $\mathrm{pH}$ Werten a) innen $\left(\mathrm{pH}_{i}\right)$ und b) außen ( $p H_{0}$. Der pH-Referenzbedingungen $\mathrm{pH}_{\mathrm{i}}=7,3 \cdot \mathrm{pH}=$ Vorzeichen der Ströme bei 
negativen Spannungen, die viel kleiner sind als das Nernst'sche Gleichgewichtspotential für Protonen

$$
E_{H^{+}}=\frac{R T}{F} \cdot 2,303 \cdot\left(p H_{i}-p H_{o}\right)
$$

mit $R=8,32 \cdot 10^{3} \mathrm{mVC} \mathrm{mol}^{-1} \mathrm{~K}^{-1}, F=9,65 \cdot 10^{4} \mathrm{C} \mathrm{mol}^{-1}$,

lässt vermuten, dass sie nicht passiv sind wie bei einem Ionenkanal, sondern den aktiven Ladungstransport einer Protonenpumpe widerspiegeln.

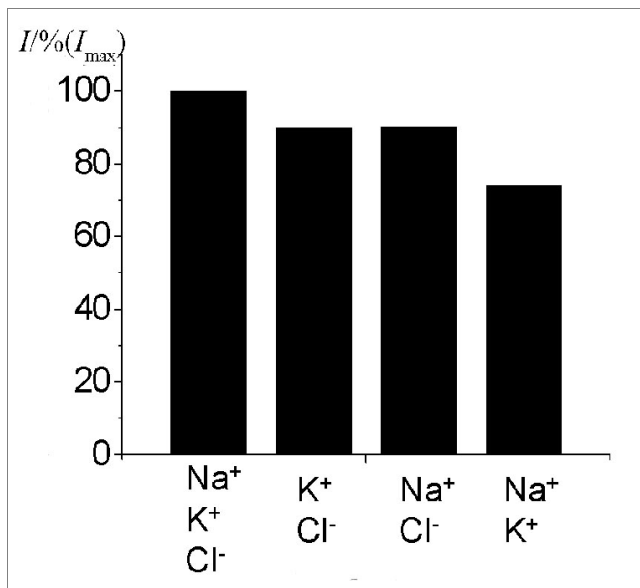

Abbildung 3.18: Einfluss verschiedener Ionen auf die lichtinduzierten Ströme durch AR. In der Badlösung vorhandene Ionen sind jeweils verzeichnet, abwesende Ionen fehlen. Die Konzentrationen betrugen bei Anwesenheit in der Badlösung $100 \mathrm{mM}$ $\left(\mathrm{Na}^{+}\right), 5 \mathrm{mM}\left(\mathrm{K}^{+}\right), 4 \mathrm{mM}\left(\mathrm{Cl}^{-}\right)$. Der Strom I ist auf den höchsten gemessenen Strom $\mathrm{I}_{\max }$ normalisiert

\subsubsection{Einfluss anderer Ionen}

Um den Effekt von $\mathrm{Na}^{+}, \mathrm{K}^{+}$und $\mathrm{Cl}^{-}$auf die lichtinduzierte Stromantwort $\mathrm{zu}$ überprüfen, wurde der Strom bei Fehlen jeweils eines dieser Ionen in der Badlösung gemessen. Abb. 3.18 zeigt für keines der Ionen einen deutlichen Effekt. Keines der vorgenannten Ionen ist demnach Träger des lichtinduzierten Stroms durch AR. 


\subsubsection{Kinetik der Stromantwort}

In Abb. 3.19 ist eine typische Meßreihe zur Ermittlung der Spannungsabhängigkeit und der Dynamik der lichtinduzierten Ströme durch AR zu sehen. Auf Licht an erscheint ein Gipfel mit schneller Kinetik, worauf der Strom langsam auf das Niveau des stationären Stroms abfällt. Auf Licht aus fällt der Strom schnell ab, wovon ein darauf folgender Abfall auf 0 A mit langsamer Kinetik zu unterscheiden ist.

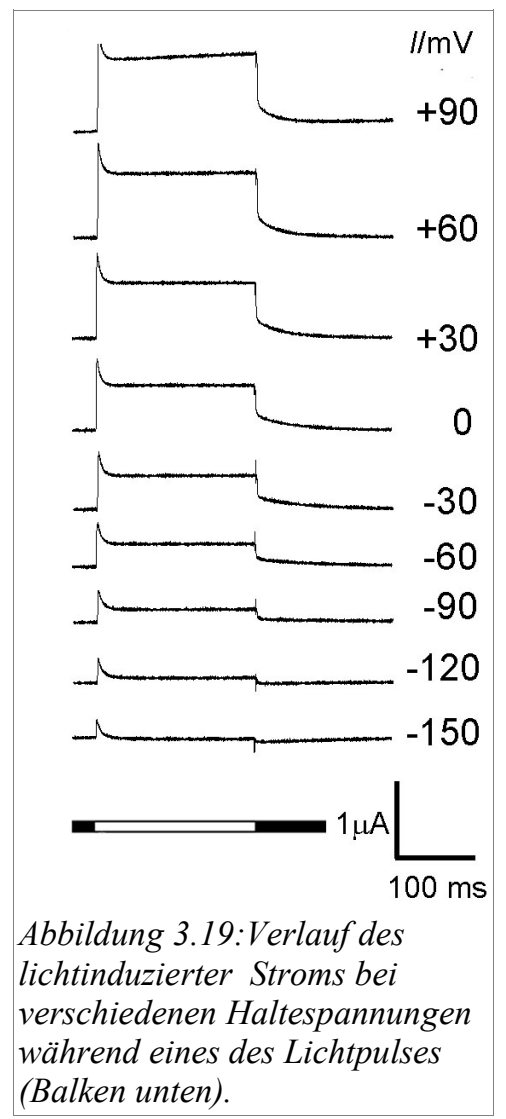

\subsubsection{Aktionsspektrum}

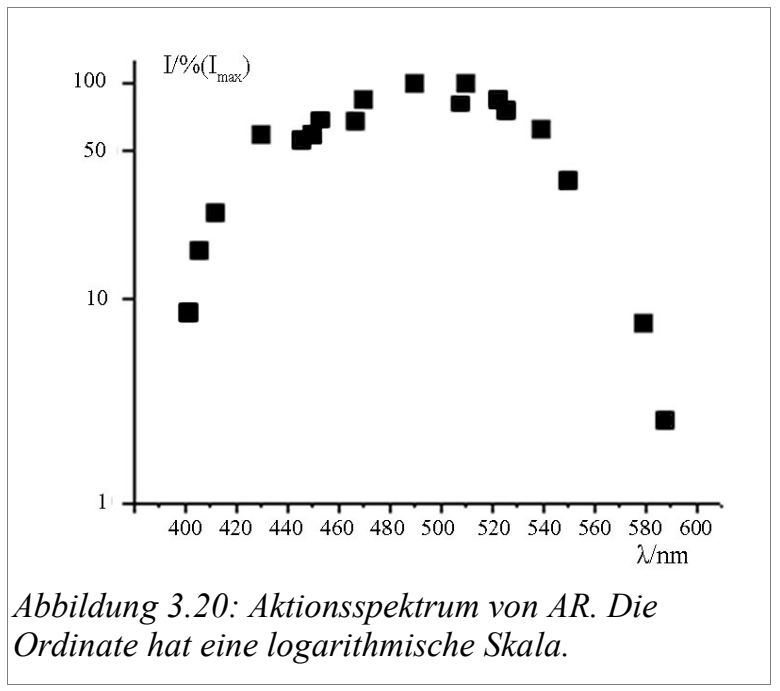

Abb. 3.20 zeigt ein Maximum von etwa $520 \mathrm{~nm}$ im Aktionsspektrum von AR. Das Aktionsspektrum gleicht in seiner Form den für visuelle Rhodopsine ermittelten Spektren (DARTNALL, 1972) und stimmt mit dem SCHILDE (1968) ermittelten und von GRADMANN (1978) reproduzierten Spektrum des schnellen photoelektrischen Effekts überein. 


\subsubsection{Lichttitration}

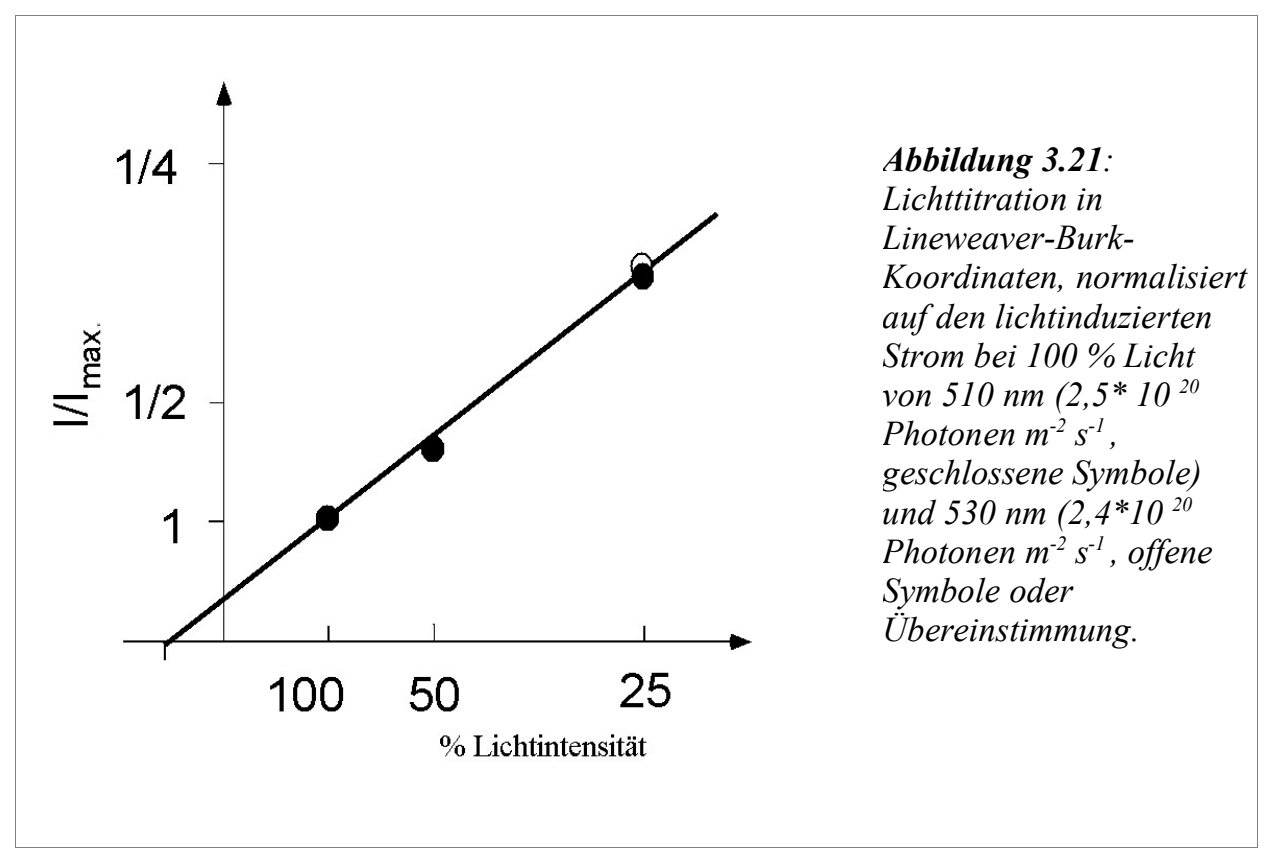

Abb. 3.21 zeigt die Lichttitration der lichtinduzierten Ströme durch AR. Das Ergebnis ist eine hohe halbmaximale Lichtintensität $J_{1 / 2}=5 \cdot 10^{20}$ Photonen $\mathrm{m}^{2} \mathrm{~s}^{-1}$. 


\section{Diskussion}

\subsection{Klassifizierung von AOP anhand von Sequenzvergleichen}

Aus der mRNA juveniler Zellen von Acetabularia acetabulum ein Transkript isoliert, das für ein Protein mit allen Kenzeichen eines Typ-1-Rhodopsins kodiert.

Es besitzt die in der Signatur der PROSITE-Datenbank für Rhodopsine des Typs 1 geforderten consensus patterns R-Y-X-[DT]-W-X-[LIVMF]-[ST]-[TV]-P-[LIVM]$[L I V M N Q]-[L I V M] \quad$ und $\quad[F Y I V]-\{N D\}-[F Y V G]-[L I V M]-D-[L I V M F]-x-[S T A]-K-x-$ $\{K\}-[F Y]$. Lys $^{218}$ ist demnach die Retinal-Bindungsstelle. Die Aminosäuren Asp ${ }^{89}$ und $\mathrm{Asp}^{100}$ entsprechen den für Protonen pumpende Rhodopsine typischen Aminosäuren in Helix III von BR und LR.

\subsubsection{Phylogenie}

Der in Abb. 3.12 gezeigte Stammbaum weist AOP eine überraschende Stellung zwischen zwei Gruppen der Opsine der Pilze zu. Der Acetabularia phylogenetisch näher stehende Organismus Pyrocystis (ein Dinoflagellat) ist im Stammbaum entfernt, während ein hypothetisches Opsin, das Oryza sativa zugeordnet wird, näher zu Oryza entfernteren Verwandten steht als zu Acetabularia. RUIZ-GONZALEZ \& MARIN (2004) bieten für dieses Phänomen mehrere alternative Erklärungen an, von denen einige horizontalen Gentransfer beinhalten. Um bessere Aussagen über die Evolution der Rhodopsine machen zu können, müssen weitere Gene aus anderen Organismen dem Vergleich hinzukommen

\subsubsection{Ermittlung der Sequenz von aop}

Vorherige Versuche, das Gen des in Acetabularia postulierten Rhodopsins zu isolieren, setzten einen Teil von chopl als Sonde zur Durchsuchung von cDNA-Bibliotheken ein (EWERS, 2002). Betrachtet man die geringe tatsächliche Übereinstimmung von chop1 und aop (10\% Identität, 21\% Ähnlichkeit, errechnet aus dem multiple sequence alignment in Abb. 3.10), wird klar, das dieser Ansatz schlechte Aussichten hatte. Nach 
den Ergebnissen von HENRY et al. (2004) steht außerdem in Zweifel, ob das gesuchte Gen in den 2002 untersuchten Phagenbanken enthalten sein konnte, da es sich um ein ausschließlich in juvenilen Zellen exprimiertes Gen handeln soll.

\subsection{Voraussage der Topologie}

Für AR wurde auf Basis der Aminosäurensequenz eine Topologie von acht TMHs vorausgesagt, von denen sieben in ihrer Position mit den für BR vorausgesagten und durch Strukturuntersuchungen belegt sind. Die für AR vorausgesagte achte TMH wäre eine strukturelle Besonderheit gegenüber den übrigen Rhodopsinen. Einige Typ-1Rhodopsine aus Chlamydomonas reinhardtii besitzen außer der konservierten Architektur der sieben TMHs noch weitere Domänen in Nähe des C-Terminus (s. KATERIYA et al., 2004), die auch TMHs enthalten und teilweise Homologie zu archebakteriellen tranducern (Htrs, FERRANDO-MAY et al., 1993) zeigen. Eine Datenbanksuche mit blastp (ALTSCHUL et al., 1990) nach solchen Homologien für AOP brachte jedoch keine Treffer (Ergebnisse nicht gezeigt).

\subsection{Elektrophysiologie}

Die durchgeführten voltage-clamp-Untersuchungen charakterisieren AR als lichtgetriebene Protonenpumpe wie BR oder LR. Im Gegensatz zu BR (GEIBEL et al, 2001) besteht keine lineare Abhängigkeit zwischen Membranspannung und lichtinduziertem Auswärtsstrom, sondern der Strom sättigt deutlich sichtbar im positiven Spannungsbereich (ca. $+60 \mathrm{mV}$ ) und etwas weniger deutlich im negativen Bereich (ca. $-130 \mathrm{mV}$ ). Da ein Wechsel des Vorzeichens des Stroms nicht beobachtet werden konnte und auf Grund der sigmoiden $I(V)$-Kurve auch nicht extrapoliert werden konnte, herrscht keine Sicherheit über die Natur der transportierten Ladung. Die deutliche $\mathrm{pH}$-Abhängigkeit der Stromantwort und die fehlende Abhängigkeit von der Anwesenheit von $\mathrm{Na}^{+}, \mathrm{Ka}^{+}$und $\mathrm{Cl}^{-}$lassen jedoch auf einen Protonenstrom schließen. Der genannte Sättigungseffekt wird bei hohen und niedrigen Lichtdosen gleichermaßen beobachtet (Daten nicht gezeigt.)

Die Dynamik der lichtinduzierten Stromantwort (Abb. 4.1) ist der von BR (GEIBEL et al, 2001) ähnlich. Der transiente Gipfel auf Einschalten des Lichts hin wurde von 


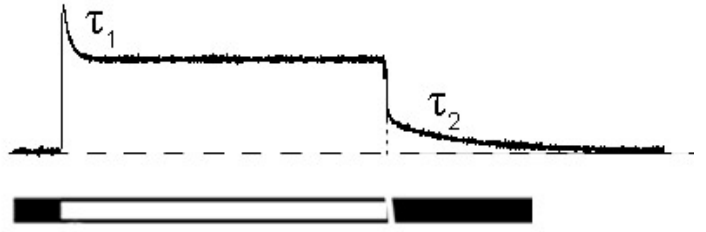

Abbildung 4.1: Die beiden langsamen dynamischen Prozesse der Verläufe lichtinduzierter Ströme durch AR mit den entsprechenden Zeitkonstanten.

GEIBEL et al. auf eine Anreicherung von $M_{410}^{E C}$ zurückgeführt.

Geht man in Analogie zu GEIBEL et al. (2001) davon aus, daß die zweite, langsame Komponente des Stromabfalls auf Ausschalten des Lichts (Zeitkonstante $\left.\tau_{2}\right)$ auf den Übergang $M_{410}^{C P} \Leftrightarrow N_{560}$ als geschwindigkeitbestimmenden Schritt zurückzuführen ist, welchen nahezu alle Rhodopsinmoleküle in der Membran noch durchmachen, ist die Anzahl der während dieses Schrittes transportierten Protonen gleich der Anzahl der angeregten Rhodopsinmoleküle in der Membran. Die transportierte Ladung Q des zweiten langsamen Abfalls ist das Integral des zeitabhängigen Stroms

$$
\int_{0}^{\infty} I_{0} \exp \left(-t / \tau_{2}\right) d t \text { mit } I_{0}: \text { Strom zu Beginn des Abfalls. }
$$

Explizit vereinfacht sich der Ausdruck zu $I_{0} \tau_{2}$. Mit den aus Abb. 3.19 abgetragenen Zahlenwerten, der Elementarladung $e=1,60 \cdot 10^{-19} \mathrm{C}$ und einer angenommenen Oberfläche der Oozyte $A \approx 2 \cdot 10^{7} \mu m^{2}$ ergibt sich eine Expressionsdichte von $2000 / \mu m^{2}$, eine um ca. eine Größenordnung höhere Dichte als die von NAGEL et al. (1995) als Mindestwert angegebene Dichte von $130 / \mu \mathrm{m}^{2}$.

\subsection{Vergleich der lichtinduzierten Ströme durch AR mit dem schnellen photoelektrischen Effekt von}

\section{Acetabularia}

Die zentrale Frage, zu deren Lösung diese Arbeit beitragen sollte, ist die nach der Natur des Photorezeptors, der in Acetabularia am Anfang des von SCHILDE (1968) erstmals beschriebenen schnellen photoelektrischen Effekt steht. Die lichtinduzierten Ströme durch AR haben ein Aktionsspektrum, dass das von SCHILDE ermittelte Aktionsspektrum des schnellen photoelektrischen Effekts sehr gut wiedergibt. Eine weitere Übereinstimmung liegt in der Dynamik der Ströme. Wie die Depolarisation des schnellen photoelektrischen Effekts (GRADMANN, 1984) setzt der lichtinduzierte 
Strom innerhalb von $\mu$ s ein. Die von GRADMANN gemessene Verzögerung liegt bei unter $10 \mu \mathrm{s}$. Im Falle von AR reicht die zeitliche Auflösung der bisher durchgeführten Messungen für eine exakte Bestimmung der Verzögerung nicht aus, sie liegt aber in jedem Fall im Bereich von einigen $\mu$ s. Auch die Lichttitration zeigt Ähnlichkeit zwischen beiden Phänomenen. Beide Effekte haben eine hohe halbmaximale Lichtintensität.

AR wäre demnach ein guter Kandidat, der Träger des schnellen photoelektrischen Effekts zu sein. Während dieser jedoch in einer transienten Depolarisation der Zelle besteht, wurde in dieser Arbeit ein Auswärtsstrom durch AR demonstriert, der statt einer Depolarisation vielmehr eine Hyperpolarisation bewirkt. Dieser Widerspruch muss noch aufgeklärt werden.

\subsection{Ausblick}

AR sollte weiter charakterisiert werden. Hier wurde gezeigt, dass die Dynamik der lichtinduzierten Ströme durch AR ähnlich der von BR ist. Spektroskopische Analysen könnten helfen, den photocycle von AR aufzuklären, der den beobachteten Phänomenen zugrundeliegt. Um die Funktion von AR als Photorezeptor des schnellen photoelektrischen Effekts in Acetabularia zu verifizieren, sind weitere Experimente nötig. So wäre es wichtig zu erfahren, wo das Gen in welcher Entwicklungsphase exprimiert wird. Beiden Ansätzen müsste eine Überexpression in E. coli vorausgehen.

Es wäre weiterhin interessant, AR in Acetabularia auf seine Beteiligung am schnellen photoelektrischen Effekt zu untersuchen. Hierzu wäre es hilfreich, Acetabularia transformieren zu können, um die Expression des Proteins auszuschalten oder zu unterdrücken. Der Anteil von AR am schnellen photoelektrischen Effekt könnte so direkt überprüft werden. 


\section{Zusammenfassung}

Hier wurde die molekulargenetische und elektophysiologische Charakterisierung von Acetabularia-Rhodopsin (AR) beschrieben, einer membranintegralen, lichtgetriebenen Protonenpumpe aus der Familie der Typ-1-Rhodopsine.

Mithilfe der reversen Transkription und der Polymerasekettenreaktion wurde auf der Grundlage einer kürzlich veröffentlichten, unvollständigen Sequenz, das gesamte Transkript eines Opsins in Form komplementärer Desoxyribonukleinsäure isoliert, kloniert und sequenziert. Das aus der abgeleitete Aminosäurensequenz resultierende hypothetische Protein hat eine mit den Rhodopsinen des Typs 1 übereinstimmende Primär- und Sekundärstruktur. Die Aminosäurensequenz von AR zeigt 21\% Identität und 38\% Ähnlichkeit mit Bacteriorhodopsin. Es scheint außer den für Rhodopsine typischen sieben transmembranen Helices noch ein weiteres Transmembransegment in Nähe des C-Terminus $\mathrm{zu}$ besitzen. Aufgrund charakteristischer konservierter Aminosäuren im aktiven Zentrum des Proteins wird in AR eine lichtgetriebene Protonenpumpe vermutet.

Um AR elektrophysiologisch zu charakterisieren, wurde es in Oozyten von Xenopus laevis funktionell exprimiert. Voltage-clamp-Untersuchungen bestätigten den lichtgetriebenen Transport von Protonen durch AR gegen ihren elektrochemischen Gradienten. Der stationäre positive Strom ist spannungsabhängig mit einer sigmoiden $I(V)$-Kurve.

AR ist das erste in einem autotrophen Eukaryoten nachgewiesene Rhodopsin, das als aktiver Ionentransporter fungiert. Der lichtinduzierte Strom durch AR zeigt Ähnlichkeiten mit dem schnellen photoelektrischen Effekt in Acetabularia. So folgt die Antwort $<50 \mu$ s auf ,Licht an“, hat eine halbmaximale Lichtintensität von $>10^{20}$ Photonen $\mathrm{m}^{-2} \mathrm{~s}^{-1}$, und das Maximum des Aktionsspektrums liegt bei $520 \mathrm{~nm}$ (550 nm in vivo). 


\section{Literaturverzeichnis}

ALTSCHUL S. F., GISH W., MILLER W., MYERS E. W., LIPMAN D. J. (1990) Basic local alignment search tool. J. Mol. Biol. 215, 403-410

BEJA O., KOONIN E. V., SUZUKI M. T., HADD A., NGUYEN L. P. (2000) Bacterial rhodopsin: evidence for a new type of phototrophy in the sea. Science 289, 1902-1906

BENNETZEN J. L. (2000) Transposable element contributions to plant gene and genome evolution. Plant Mol. Biol. 42(1), 251-269

BERNSTEIN F. C., KOETZLE T. F., WILLIAMS G. J., MEYER E. F. Jr., BRICE M. D., RODGERS J. R., KENNARD O., SHIMANOUCHI T., TASUMI M. (1977) The Protein Data Bank: a computer-based archival file for macromolecular structures. J. Mol. Biol. 112(3), 535-542

BIEZKE J. A., BRAUN E. L., BEAN L. E., KANG S., NATVIG D. O., BORKOVICH K. O. (1999) The nop-1 gene of Neurospora crassa encodes a seven transmembrane helix retinal-binding protein homologous to archaeal rhodopsins. Proc. Natl. Acad. Sci. USA 96, 8034-8039

BOGOMOLNI R. \& SPUDICH J. (1982) Identification of a third rhodopsin-like pigment in phototactic Halobacterium halobium. Proc. Natl. Acad. Sci. USA 79, 62506254

BOYD D., SCHIERLE C., BECKWITH J. (1998) How many membrane proteins are there? Prot. Sci. 7 201-205

BROWN L. S. (2004) Fungal rhodopsins and opsin-related proteins: eukaryotic homologues of bacteriorhodopsin with unknown functions. Photochem. Photobiol. Sci. 3(6), 555-565

BUCHER P. \& BAIROCH A. (1994) A generalized profile syntax for biomolecular sequences motifs and its function in automatic sequence interpretation. In: Proceedings 2nd International Conference on Intell (Altman R., Brutlag D., Karp P., Lathrop R., Searls), 53-61, AAAIPress, Menlo Park

BULLOCK W. O., FERNANDEZ J. M., SHORT J. M. S. (1987) X11-Blue: A High Efficiency Plasmid Transforming recA Escherichia coli Strain With Beta-Galactosidase Selection. BioTechniques 5(4), 376-379

CLINE J., BRAMAN J. C., HOGREFE H. H. (1996) PCR fidelity of Pfu DNA polymerase and other thermostable DNA polymerases. Nucleic Acids Research 24, 3546

CSERZO M., WALLIN E., SIMON I., von HEIJNE G., ELOFFSON A. (1997)

Prediction of transmembrane alpha-helices in prokaryotic membrane proteins: the dense alignment surface method. Protein Eng. 10, 673-676 
D'AQUILA R. T., BECHTEL L. J., VIDELER J. A., ERON J. J., GORCZYCA P., KAPLAN J. C. (1991) Maximizing sensitivity and specificity of PCR by preamplification heating. Nucleic Acids Res. 19(13), 3749

DARTNALL H. J. A. (1972) Photochemistry of visual pigments. In: Handbook of sensory physiology (DARTNALL H. J. A., ed.), 122-145, Springer, New York

DEININGER W., FUHRMANN M., HEGEMANN P. (2000) Opsin evolution: Out of wild green yonder? Trends Gen. 16 (4), 158-159

DON R. H., COX P. T., WAINWRIGHT B. J., BAKER K., MATTICK J. S. (1991) 'Touchdown' PCR to circumvent spurious priming during gene amplification. Nucleic Acids Res. 19(14),

DUNN R., MCCOY J., SIMSEK M., MAJUMDAR A., CHANG S. H., RAJBHANDARY U. L., KHORANA H. G. (1981) The bacteriorhodopsin gene. Proc. Natl. Acad. Sci. USA 78(11), 6744-6748

ESCHENFELDT W. H. (1983) Homopolimeric tailing. Meth. Enzymol. 100, 96-116

EWERS D. (2002) Identifizierung von Rhodopsin aus Acetabularia cliftonii und Dunaliella bioculata. Diplomarbeit, Georg-August-Universität zu Göttingen

FEDORCSAK I., EHRENBERG L. (1966) Effects of diethylpyrocarbonate and methylmethanesulfonate on nucleic acids and nucleases. Acta Chem. Scand. 20, 107

FERRANDO-MAY E., KRAH M., MARWAN W., OESTERHELT, D. (1993) The methyl-accepting transducer protein HtrI is functionally associated with the photoreceptor sensory rhodopsin I in the archaeon Halobacterium salinarium. EMBO J. 12(8), 2999-3005

FROHMAN M. A., DUSH M. K., MARTIN G. R. (1988) Rapid production of fulllength cDNAs from rare transcripts: Amplification using a single gene-specific oligonucleotide primer. Proc. Nati. Acad. Sci. USA 85, 8998-9002

GEIBEL S., FRIEDRICH T., ORMOS P., WOOD P. G., NAGEL G., BAMBERG E. (2001) The Voltage-Dependent Proton Pumping in Bacteriorhodopsin is Characterized by Optoelectric Behavior. Biophys. J. 81, 2059-2068

GIBBS A. J., MCINTYRE G. A. (1970) The Diagram, a Method for Comparing Sequences - Its Use with Amino Acid and Nucleotide Sequences. Eur. J. Biochem. 16, $1-11$

GIBOR A. (1966) Acetabularia: a useful giant cell. Sci. Am. 215 (5), 118-124

GRADMANN D. (1978) Green light (550 nm) inhibits electrogenic Cl- pump in the Acetabularia membrane by permeability increase for the carrier ion. J. Membr. Biol. 44 (1), $1-24$

GRADMANN (1984) Electrogenic Cl- pump in the marine alga Acetabularia. In: 
Chloride Transport Coupling in Biological Membrane (Gerenser G. A., ed.) Elsevier Science Publishers B. V.14-52

GRIGORIEFF N., CESKA T. A., DOWNING K. H., BALDWIN J. M., HENDERSON R. (1996) Electron-crystallographic refinement of the structure of bacteriorhodopsin. J. Mol. Biol. 259, 393-421

GRYGORCZYK R., HANKE-BAIER P., SCHWARZ W., PASSOW H. (1989) Measurement of erythroid band 3 protein-mediated anion transport in mRNA-injected oocytes of Xenopus laevis. Methods Enzymol. 173:453-466.. Methods Enzymol. 173, 453-466

GUEX, N. \& PEITSCH, M. C. (1997) SWISS-MODEL and the Swiss-PdbViewer: An environment for comparative protein modeling. Electrophoresis 18, 2714-2723

GUSTAFSSON C., GOVINDARAJAN S., MINSHULL J. (2004) Codon bias and heterologous protein expression. Trends. Biotechnol. 22(7), 346-353

HALL T. A. (1999) BioEdit: a user-friendly biological sequence alignment editor and analysis program for Windows 95/98/NT. Nucl. Acids Symp. Ser. 41, 95-98

HAUPTS U., TITTOR J., OESTERHELT D. (1999) Closing in on Bacteriorhodopsin: Progress in Understanding the Molecule. Annu. Rev. Biophys. Biomol. Struct. 28, 367399

HENDERSON R. \& SCHERTLER G. F. X. (1990) the structure of bacteriorhodopsin and its relevance to the visual opsins and other seven-helix G-protein coupled receptors. Phil. Trans. R. Soc. London Ser. B 326, 379-389

HENIKOFF S. \& HENIKOFF J. (1992) Amino acid substitution matrices from protein blocks. Proc. Nati. Acad. Sci. USA 89, 10915-10919

HENRY I. M., WILKINSON M. D., HERNANDEZ J. M., SCHWARZ-SOMMER Z., GROTEWOLD E., MANDOLI D. F. (2004) Comparison of ESTs from juvenile and adult phases of the giant unicellular green alga Acetabularia acetabulum. BMC Plant Biol. 4, 3-14

HIGGINS D.G. \& SHARP P.M. (1988) CLUSTAL: a package for performing multiple sequence alignment on a microcomputer. Gene 73, 237-244

HOFMANN K. P. (1999) Signalling states of photoactivated rhodopsin. Novartis Found. Symp. 224, 158-175

HORWITZ J. P., CHUA J., CURBY R. J., TOMSON A. J., DAROOGE M. A., FISHER B. E., MAURICIO J., KLUNDT I. (1978) Substrates for cytochemical demonstration of enzyme activity. I. Some substituted 3-indoyl-glycopyranosides. J. Med. Chem. 574, 7

JOSHI C. P., ZHOU H., HUANG X., CHIANG V. L. (1997) Context sequences of translation initiation codon in plants. Plant Mol. Biol 35, 993-1001 
KAMMANN M., LAUFS J., SCHELL J., GRONENBORN B. (1989) Rapid insertional mutagenesis of DNA by polymerase chain reaction (PCR). Nucleic Acids res. 17, 5404

KATERIYA S., NAGEL G., BAMBERG E., HEGEMANN P. (2004) "Vision" in single-celled algae. News. Physiol. Sci. 19, 133-137

KAZAZIAN H. H. Jr. (2004) Mobile elements: drivers of genome evolution. Science 303(5664), 1626-1632

KOZAK M. (1986) Point mutations define a sequence flanking the AUG initiator codon that modulates translation by eukaryotic ribosomes. Cell 44, 283-292

KOZAK M. (1987) An analysis of 50 5'-noncoding sequences from 699 vertebrate messenger RNAs. Nucleic Acids res. 15, 8125-8148

KUMAR S., TAMURA K., NEI M. (2004) MEGA3: Integrated software for Molecular Evolutionary Genetics Analysis and sequence alignment. Brief. Bioinformatics 5, 150163

LANYI, J. K. (2001) X-Ray Crystallography of Bacteriorhodopsin and Its Photointermediates: Insights into the Mechanismof Proton Transport. Biokhimiya 66, 1477-1482

LOZIER R. H., BOGOMOLNI R. A., STOECKENIUS W. (1975) Bacteriorhodopsin: a light-driven proton pump in Halobacterium Halobium. Biophys. J. 15 (9), 955-962

LUECKE H., SCHOBERT B., RICHTER H. T., CARTAILLER J. P., LANYI J. K. (1999) Structure of Bacteriorhodopsin at 1.55 Ångstrom Resolution. J.Mol.Biol. 291, 899

MESSING J. (1983) New M13 vectors for cloning. Methods Enzymol. 101, 20

MÜLLER D. (1962) On year and lunar periodicity phenomenon in several brown algae. Bot. Mar. 4, 140-155

MULLIS K. B. \& FALOONA F. A. (1987) Specific synthesis of DNA in vitro via a polymerase-catalyzed chain reaction. Meth. Enz. 155, 335-350

NAGEL G., MOECKEL B., BÜLDT G., BAMBERG E. (1995) Functional expression of bacteriorhodopsin in oocytes allows direct measurement of voltage dependence of light induced $\mathrm{H}+$ pumping. FEBS Letters 377, 263-266

NAGEL G., OLLIG D., FUHRMANN M., KATERIYA S., MUSTI A. M., BAMBERG E., HEGEMANN P. (2002) Channelrhodopsin-1: A light-gated proton channel in green algae. Science 296, 2395-2398

NAGEL G., SZELLAS T., KATERIYA S., ADEISHVILI N., HEGEMANN P., BAMBERG E. (2005) Channelrhodopsins: directly light-gated cation channels. Biochem. Soc. Trans. , 863-866 
OESTERHELT, D. (1999) Photosynthese der zweiten Art: Die halophilen Archaea. In: (D. Häder, ed.), 146-161, Georg Thieme Verlag, Stuttgart

ORREGO C. (1990) Organising a laboratory for PCR work. In: PCR Protocols. A Guide to Methods and Applications (Innis M. A., Gelfand D. H., Sninsky J. J., White T. J., eds.), 447-454, Academic, San Diego, CA

OSAWA, S. JUKES, T. H. WATANABE K., MUTO A. (1992) Recent evidence for evolution of the genetic code. Microbiol. Rev. 56(1), 229-264.

PEPE I. M., CUGNOLI C. (1992) Retinal photoisomerase: Role in invertebrate visual cells. J. Photochem. Photobiol. B 13, 5-17

PROUDFOOT N. J., BROWNLEE, G. G. (1976) 39 non coding region sequences in eukaryotic messenger RNA. Nature 263, 211-214

PROVASCOLI L., MCLAUGHLIN J. J. A., DROOP M. R. (1957) The development of artificial media for marine algae. Arch. Mikrobiol. 25, 392

ROTHNIE H. M. (1996) Plant mRNA 3'-end formation. Plant Mol. Biol. 32, 43-61

RUIZ-GONZALEZ M. X. \& MARIN I. (2004) New Insights into the Evolutionary History of Type 1 Rhodopsins. J. Mol. Evol. 58, 348-358

SAIKI R. K., GELFAND D. H., STOFFEL S., SCHARF S. J., HIGUCHI R., HORN G.T., MULLIS K. B., EHRLICH H (1988) Primer directed enzymatic amplification of DNA with a thermostable DNA Polymerase. Science 239, 487-91

SAIKI R. K., SCHARF S., FALOONA F., MULLIS K. B., HORN G. T., ERLICH H. A., ARNHEIM N. (1985) Enzymatic amplification of beta-globin genomic sequences and restriction site analysis for diagnosis of sickle cell anemia. Science 230, 1350-1354

SAITOU N., NEI M. (1987) The neighbor-joining method: A new method for reconstructing phylogenetic trees. Mol. Biol. Evol. 34, 544-545

SASAKI J., BROWN L. S., CHON Y. S., KANDORI H., MAEDA A. (1995)

Conversion of bacteriorhodopsin into a chloride ion pump. Science 269, 73-75

SCHILDE C. (1968) Schnelle photoelektrische Effekte der Alge Acetabularia. Z. Naturforsch. 23 (b), 1369

SCHNEIDER S. U., LEIBLE M. B., YANG X.P. (1998) Strong homology between the small subunit of ribulose-1,5-bisphosphate carboxylase/oxygenase of two species of Acetabularia and the occurrence of unusual codon usage. Mol. Gen. Genet. 218, 445452

SCHOBERT B. \& LANYI J. K. (1982) Halorhodopsin is a light-driven chloride pump. J. Biol. Chem. 257, 10306-10313 
SCHWEIGER H. G., DEHM P., BERGER S. (1977) Culture conditions for Acetabularia. In: Progress in Acetabularia research (C.L.F. Woodstock, ed.), 319-330, Academic Press, New York

SERIKAWA K. A. \& MANDOLI, D. F. (1999) Aaknox1, a kn1-like homeobox gene in Acetabularia acetabulum, undergoes developmentally regulated subcellular localization. Plant Mol. Biol. 41, 785-793

SHAFRIR Y. \& GUY H. R. (2004) STAM: Simple Transmembrane Alignment Method. Bioinformatics 20 (5), 758-769

SINESHCHEKOV O. A., JUNG K. H., SPUDICH J. L. (2002) Two rhodopsins mediate phototaxis to low- and high-intensity light in Chlamydomonas reinhardtii. Proc. Natl. Acad. Sci. USA 99, 8689-8694

SPUDICH J. L., YANG C. S., JUNG K. H., SPUDICH E. N. (2000) Retinylidene Proteins: Structures and Functions from Archaea to Humans. Annu. Rev. Cell Dev. Biol. 16, 365-392

STEWART A. K., CHEMOVA M. N., KUNES Y. Z., ALPER S. L. (2001) Regulation of AE2 anion exchanger by intracellular $\mathrm{pH}$ : critical regions of the $\mathrm{NH} 2$-terminal cytoplasmic domain. Am. J. Physiol. Cell Physiol. 281 (C), 1344

STOEKENIUS D. \& OESTERHELT W. (1973) Functions of a New Photoreceptor Membrane. Proc. Nat. Acad. Sci. USA 70 (10), 2853-2857

THOMPSON J. D., GIBSON T. J., PLEWNIAK F., JEANMOUGIN F., HIGGINS D. G. (1997) The ClustalX windows interface: flexible strategies for multiple sequence alignment aided by quality analysis tools. Nucl. Acids Res. 25, 4876-4882

TYAGI R., LAI R., DUGGLEBY R.G. (2004) A new approach to 'megaprimer' polymerase chain reaction mutagenesis without an intermediate gel purification step. BMC Biotech. 4, 1-4

ULLMANN A., JACOB F., MONOD J. (1967) Characterization by in vitro complementation of a peptide corresponding to an operator-proximal segment of the beta-galactosidase structural gene of Escherichia coli. J. Mol. Biol. 24, 339-343

VARO G. \& LANYI J. K. (1991) Thermodynamics and energy coupling in the bacteriorhodopsin photocycle. Biochemistry 30, 5016-5022

WALLACE I. M., BLACKSHIELDS G., HIGGINS D. G. (2005) Multiple sequence alignments. Curr. Opin. Struct. Biol. 15(3), 261-266

WASCHUK S. A., BEZERRA A. G. Jr., SHI L., BROWN L. S. (2005) Leptosphaeria rhodopsin: Bacteriorhodopsin-like proton pump from a eukaryote. Proc. Natl. Acad. Sci. USA 19, 6879-6883

ZHAO J., HYMAN L., MOORE C. (1999) Formation of mRNA 3' Ends in Eukaryotes: Mechanism, Regulation, and Interrelationships with Other Steps in mRNA Synthesis. 
Microb.Mol. Biol. Rev. 63, 405-445 



\section{Lebenslauf}

\section{Persönliche Daten}

David Ewers

Geboren am 21.08.1976 in Hannover

Staatsangehörigkeit: deutsch

\section{Schulausbildung}
$1983-1987$
Grundschule Lauenförde
$1987-1996$
Städtisches Gymnasium Beverungen
Mai 1996
Abitur

\section{Grundwehrdienst}

September 1996 - Juni 1997

\section{Hochschulstudium}

WS 1997/1998 - SS 2002

Studium der Biologie an der Georg-August-Universität zu Göttingen

WS 1999/2000

Vordiplom

WS 2001/2002 - SS 2002

Diplomarbeit in der Abteilung Biophysik der Pflanze (Prof. Dr. D. Gradmann)

SS 2002

Diplom; Titel der Diplomarbeit: „Identifizierung von Rhodopsin aus Dunaliella bioculata und Acetabularia cliftonii"

SS $2002-$ WS 2005/2006

Dissertation in der Abteilung Biophysik der Pflanze

WS $2005 / 2006$

Promotion; Titel der Dissertation: „Acetabularia-Rhodopsin, eine lichtgetriebene Protonenpumpe aus einem autotrophen Eukaryoten" 